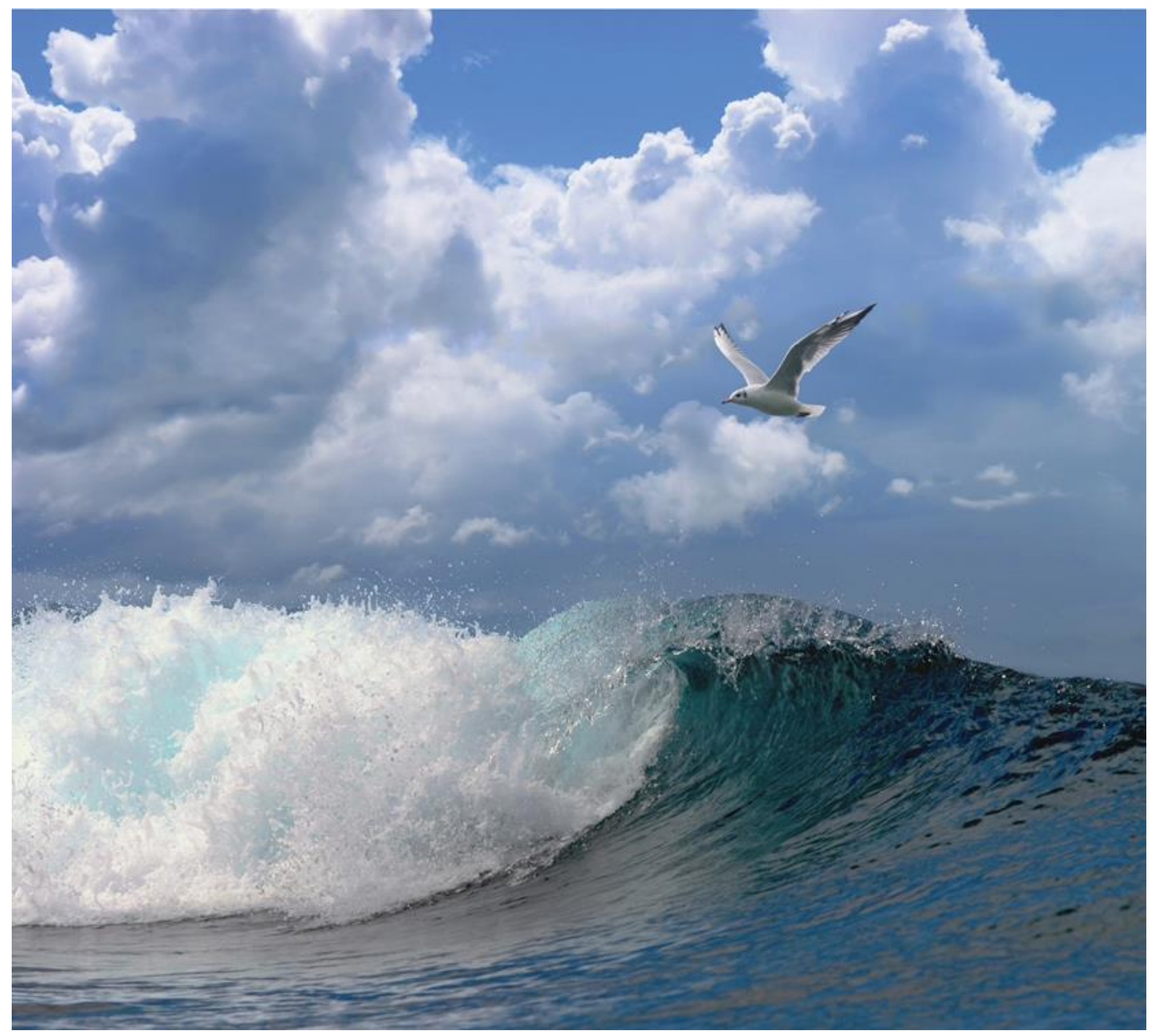

\title{
Small pelagic fish and zooplankton in the Dutch coastal surf zone during the EGS- II survey in 2017-2018
}




\section{Small pelagic fish and zooplankton in the Dutch coastal surf zone during the EGS-II survey in 2017-2018}

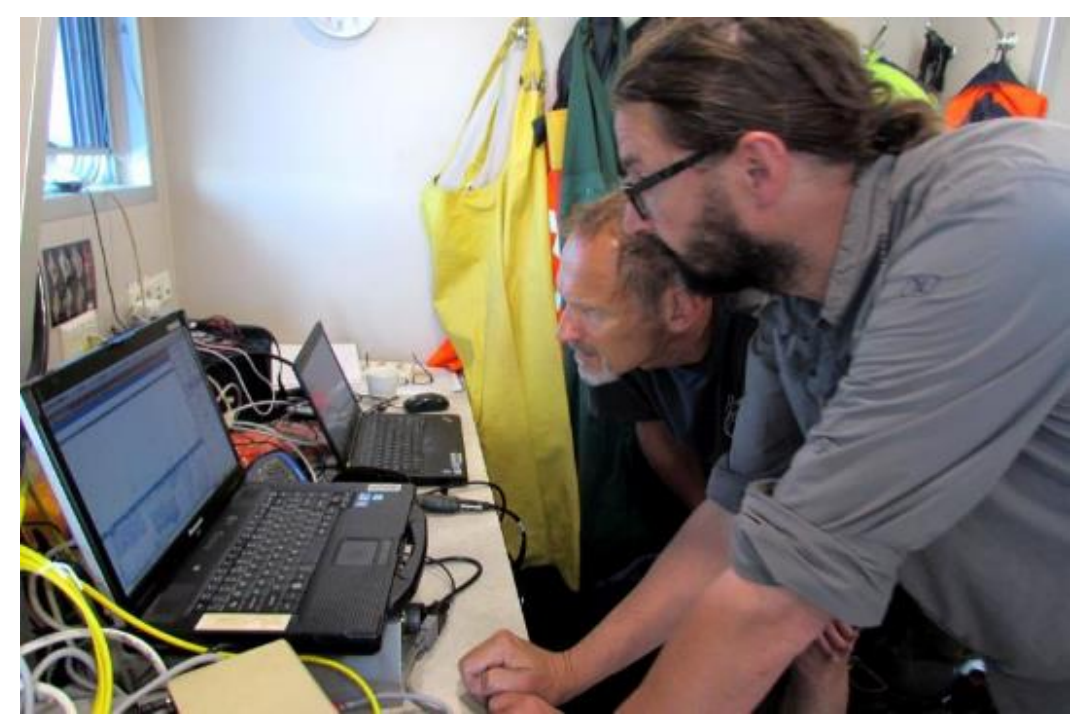

Author(s): $\quad$ Bram Couperus, Serdar Sakinan and Dirk Burggraaf 
Keywords: Pelagic Fish, Dutch coast, shallow.

Client: $\quad$ RWS-WVL, hoogwaterveiligheid

T.a.v.: Petra Damsma

Postbus 17

8200 AA Lelystad

This report can be downloaded for free from https://doi.org/10.18174/525593

Wageningen Marine Research provides no printed copies of reports

Wageningen Marine Research is ISO 9001:2015 certified.

Photo cover: Martin Baptist

\section{(C) Wageningen Marine Research}

Wageningen Marine Research, an institute Wageningen Marine Research accepts no liability for consequential damage, nor within the legal entity Stichting for damage resulting from applications of the results of work or other data Wageningen Research (a foundation under obtained from Wageningen Marine Research. Client indemnifies Wageningen Dutch private law) represented by Dr. Marine Research from claims of third parties in connection with this application. M.C.Th. Scholten, Managing Director All rights reserved. No part of this publication may be reproduced and / or published, photocopied or used in any other way without the written permission

KvK nr. 09098104, of the publisher or author.

WMR BTW nr. NL 8113.83.696.B16.

Code BIC/SWIFT address: RABONL2U

IBAN code: NL 73 RABO 0373599285 


\section{Contents}

$\begin{array}{lr}\text { Summary } & 5\end{array}$

$\begin{array}{lr}\text { Samenvatting } & 7\end{array}$

1 Introduction $\quad 9$

1.1 Ecological effects of sand nourishments 9

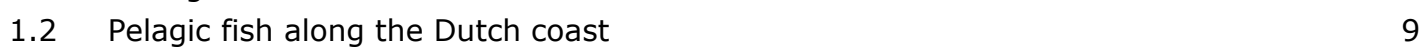

$\begin{array}{ll}1.3 & \text { Environmental conditions } \\ \end{array}$

2 Methods $r 1$

$2.1 \quad$ Acoustic set up $\quad 11$

2.2 Variability in distribution biomass estimation $\quad 12$

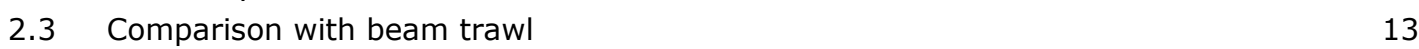

2.4 Impact of depth, time of the day and tidal phase $\quad 13$

$\begin{array}{ll}2.5 & \text { Possible escape behaviour of fish } \\ 2.6 & 13\end{array}$

$\begin{array}{lll}2.6 & \text { Zooplankton sampling } & 14\end{array}$

$\begin{array}{llr}3 & \text { Results } & 16\end{array}$

3.1 Distribution at the coastal locations $\quad 16$

3.2 Comparison of acoustics with the beam trawl results 19

$\begin{array}{lll}3.3 & \text { Possible escape behaviour } & 21\end{array}$

3.4 Impact of tidal phase, time of the day and depth 22

$\begin{array}{ll}3.5 & \text { Zooplankton } \\ \end{array}$

4 Discussion and conclusions $r 2$

$\begin{array}{lll}4.1 & \text { Distribution and abundance } & 29\end{array}$

$\begin{array}{lll}4.2 & \text { Acoustics and beam trawl } & 30\end{array}$

$\begin{array}{lll}4.3 & \text { Tide and time of the day } & 31\end{array}$

4.4 Avoidance? $\quad 31$

$\begin{array}{lll}4.5 & \text { Impact of sand nourishments } & 31\end{array}$

$\begin{array}{ll}4.6 & \text { Zooplankton } \\ \end{array}$

5 Conclusions $\quad 34$

$6 \quad$ Advice for future work $\quad 35$

$\begin{array}{lr}\text { References } & 36\end{array}$

$\begin{array}{llr}7 & \text { Quality Assurance } & 38\end{array}$

$\begin{array}{lr}\text { Justification } & 39\end{array}$

$\begin{array}{lr}\text { Annex } 1 \text { - Sample locations } & 40\end{array}$

Annex 2 - Calculation of TS length relationship of small clupeids at $200 \mathrm{kHz}$

$\begin{array}{lr}\text { Annex } 3 \text { - Beam trawl catches } & 45\end{array}$

$\begin{array}{ll}\text { Annex } 4 \text { - NASC distribution maps } & 46\end{array}$ 


\section{Summary}

In the period 12 June to 9 July 2017 and 18 to 22 June 2018, Wageningen Marine Research carried out a multidisciplinary survey in Dutch coastal waters commissioned by Rijkswaterstaat. The survey was designed to determine the distribution and abundance of fish in the coastal zone and to collect data from (a)biotic factors that determine this distribution. The aim was to use this data to predict the possible effects of sand nourishment in the coastal zone on fish. This report describes the activities and the results of the part of the survey directed to pelagic fish and zooplankton.

Although it was not expected that sand nourishments would have a large direct impact on small pelagic fish and zooplankton, it was decided to enhance knowledge by including these groups as targets because of their important role in the ecosystem. However, because the focus of coastal research in the past has been on demersal fish, there is little experience with pelagic fish monitoring methods in this area. Therefore, the objectives for small pelagic fish and zooplankton are more exploratory: (1) How variable in time and space is the distribution of pelagic fish along the coast? (2) Are the variations in distribution of pelagic fish correlated with tide and/or time of the day? (3) Can beam trawl catches be used as an index of pelagic fish in the sandy coastal zone of the Netherlands? (4) Do fish schools remain undetected due to escape behaviour from the vessel in the shallow environment of the coast? (5) The objective of the zooplankton sampling during the survey was to make a preliminary description of the zooplankton community during the survey as a reference for future research on diet of pelagic fish in the Dutch near coastal zone.

Hydro acoustic measurements were carried out in the coastal zone with a calibrated Simrad EK80 echosounder with a splitbeam $200 \mathrm{kHz}$ transducer which was deployed at the bow of the vessel. The measurements were carried out in four areas, South Holland, North Holland, Texel and Schiermonnikoog. Five transects (at Schiermonnikoog six) with seven sample locations from the beach to a depth of 12 meters were planned in each of these areas. The acoustic measurements were made in the $3-12 \mathrm{~m}$ depth zone during - and between sampling of demersal fish with a $3 \mathrm{~m}$ beam trawl. For purpose of testing whether fish schools at the bow remain undetected due to escape behaviour (objective 4), additional acoustic measurements were carried out simultaneous with a $200 \mathrm{kHz}$ transducer mounted in a towed body sheering away from the vessel. During the survey zooplankton samples were collected with a WP2 net with $200 \mu \mathrm{m}$ mesh size.

De main conclusions of this study were: (1) The observed densities of pelagic fish varied greatly between and within the different locations, which is in general not unusual for pelagic fish. The densities in 2017 along the west coast ranged from 29 to $209 \mathrm{~kg} / \mathrm{ha}$ and were of the order of magnitude of an earlier study in the Marsdiep and are much higher than observed densities of demersal fish along the Dutch coast. The observed density at Schiermonnikoog in 2018 was much lower ( $4 \mathrm{~kg} / \mathrm{ha}$ ). (2) A GAM analysis in which the effect of the time of the day, the tide and depth were compared with the estimates of the fish quantities, indicates that the large observed variations in fish abundance cannot be explained by these factors. (3) In the catches of the beam trawl, the pelagic species herring and sprat were found to dominate. It therefore seems likely that most acoustically recorded fish schools consisted of these species. However, there was no relationship between the quantity of herring and sprat in the catch and the schools observed with the echosounder. The relationship was even negative: large concentrations on the echo sounder coincided to virtually no pelagic fish in the beam trawl catch. It is therefore recommended that future coastal surveys must be carried out with a (semi) pelagic net that is suitable for catching schooling fish. (4) There was no significant difference between the amount of fish measured at the bow and the amount of fish at $8 \mathrm{~m}$ beside the vessel. Therefore, it is likely that fish abundance is not underestimated due to possible avoidance behaviour. It is concluded that the set up with the transducer mounted in a depressor at the bow can be used for this type of acoustic fish surveys in the shallow coastal zone.

The current study has contributed to the development of methodologies to study small pelagic fish in the Dutch coastal zone, but did not give indications whether sand nourishments have direct impact on small pelagic fish. We hypothesize that sand nourishment activities may temporally affect school size and distribution due to changes in visibility. In addition, on the long term the two sandeel species (Ammodytes spp.), which spend part of their life buried in the sand, may be subject to changes in distribution due to changes in silt content and sand particle size. To test this, future studies should 
include night time bottom sampling. The acoustic set up used in this study, in combination with proper fishing gear, is probably suitable to carry out experiments to test changes in pelagic species distribution during and shortly after sand nourishment activities.

(5) The catches were dominated by the dinoflagellate Noctiluca scillitans, the numbers in the samples were an order of magnitude higher than the sum of all other taxa. Apart from N. scillitans,

zooplankton consisted mainly of Calanoida and to a lesser extend of Appendicularia, Cladocera, larvae of Bivalvia and larvae of Polychaeta. These findings are in line with Van Ginderdeuren (2014b) off the Belgium coast. 


\section{Samenvatting}

Wageningen Marine Research heeft in de periode 12 juni t / m 9 juli 2017 en 18 t / m 22 juni 2018 in opdracht van Rijkswaterstaat een multidisciplinair onderzoek uitgevoerd in de Nederlandse kustwateren. Het onderzoek was bedoeld om de verspreiding en de hoeveelheid vis in de kustzone te bepalen en om gegevens te verzamelen van (a)biotische factoren die deze verspreiding bepalen. Het doel was om met deze gegevens de mogelijke effecten van zandsuppletie in de kustzone op vissen te voorspellen. Dit rapport beschrijft de activiteiten en de resultaten van het deel van het onderzoek dat was gericht op pelagische vis en zoöplankton.

Hoewel niet wordt verwacht dat zandsuppleties een grote directe impact hebben op kleine pelagische vis en zoöplankton, werden deze groepen wel opgenomen in het onderzoek vanwege hun grote bijdrage aan het ecosysteem. Doordat het kustonderzoek in het verleden echter vooral op demersale vissen gericht is, is er in dit gebied weinig ervaring met monitoringsmethoden voor pelagische vis. Daarom zijn de doelstellingen met betrekking tot kleine pelagische vis en zoöplankton meer verkennend van aard: (1) Hoe variabel in tijd en ruimte is de verspreiding van pelagische vissen langs de kust? (2) Zijn de variaties in de verspreiding van pelagische vis gecorreleerd met getij en/of tijd van de dag? (3) Kunnen de vangsten van een boomkor worden gebruikt als index voor pelagische vis in de zandige zone voor de Nederlandse kust? (4) Blijven visscholen onopgemerkt door ontsnapping voor het schip in de ondiepe omgeving van de kust? (5) Het doel van de zoöplanktonbemonstering in dit onderzoek was om een voorlopige beschrijving te geven van de zoöplanktongemeenschap als referentie voor toekomstig onderzoek naar het dieet van pelagische vissen in het Nederlandse kustgebied.

Hydro-akoestische metingen werden uitgevoerd in de kustzone met een gekalibreerde Simrad EK80echolood met een splitbeam $200 \mathrm{kHz}$-transducer die werd ingezet bij de boeg van het schip. De metingen zijn uitgevoerd in vier deelgebieden, Zuid-Holland, Noord-Holland, Texel en Schiermonnikoog. In elk van deze gebieden waren vijf transecten (op Schiermonnikoog 6) gepland met zeven monsterlocaties vanaf het strand tot een diepte van twaalf meter. De akoestische metingen zijn uitgevoerd in de 3-12 m dieptezone tijdens - en tussen de bemonsteringen met de boomkor. Om te testen of visscholen bij de boeg worden gemist als gevolg van ontsnappingsgedrag (4), werden gelijktijdig aanvullende akoestische metingen uitgevoerd met een $200 \mathrm{kHz}$-transducer die was gemonteerd in een gesleepte towed body dat van het vaartuig wegscheert.

De belangrijkste conclusies van dit onderzoek waren: (1) De waargenomen dichtheden van pelagische vissen varieerden sterk tussen en binnen de verschillende locaties, wat niet ongebruikelijk is voor pelagische vissen. De dichtheden in 2017 langs de westkust varieerden van 29 tot $209 \mathrm{~kg} / \mathrm{ha}$ en lagen in de orde van grootte van een eerdere studie in het Marsdiep en zijn veel hoger dan waargenomen dichtheden van demersale vissen in jaarlijks uitgevoerd visonderzoek langs de kust. De waargenomen dichtheid bij Schiermonnikoog in 2018 was veel lager (4 kg / ha). (2) Een GAM-analyse waarin het effect van de tijd van de dag, het getij en de diepte werden vergeleken met de schattingen van de vishoeveelheden, geeft aan dat de grote waargenomen variaties in de visrijkdom niet kunnen worden verklaard door deze factoren. (3) De vangsten van de boomkor werden gedomineerd door de pelagische vissoorten haring en sprot, zodat het waarschijnlijk lijkt dat de meeste akoestisch geregistreerde visscholen uit deze soorten bestonden. Er werd echter geen verband gevonden tussen de hoeveelheid haring en sprot in de boomkorvangsten en de akoestisch waargenomen visscholen. Er lijkt zelfs een negatieve relatie te bestaan: wanneer er grote concentraties op het echolood worden waargenomen, zitten er vrijwel geen pelagische vissoorten in de vangst. Geadviseerd wordt om in toekomstige kustonderzoek gebruik te maken van een (semi) pelagisch net dat geschikt is voor het vangen van scholende vis. (4) Er is geen significant verschil was tussen de hoeveelheid gemeten vis bij de boeg en de hoeveelheid vis $8 \mathrm{~m}$ naast het schip. Dit wijst erop dat het aantal visscholen waarschijnlijk niet wordt onderschat als gevolg van het mogelijk ontwijken van het schip voordat ze gedetecteerd kunnen worden. Dit duidt erop dat de hier gebruikte opstelling met een transducer gemonteerd in een depressor bij de boeg gebruikt kan worden voor dit type akoestische visonderzoek in de ondiepe kustzone. 
De huidige studie heeft bijgedragen aan de ontwikkeling van methodologieën om meer kennis te verwerven over de kleine pelagische vis in de Nederlandse kustzone, maar heeft geen indicatie gegeven over mogelijk directe invloed van zandsuppleties. Mogelijk hebben zandsuppletie-activiteiten een tijdelijke invloed op de omvang en distributie van visscholen als gevolg van veranderingen in het doorzicht van het water. Op langere termijn kunnen de twee soorten zandspiering (Ammodytes spp.) onderhevig zijn aan veranderingen in de verspreiding als gevolg van veranderingen in slibgehalte en grootte van zanddeeltjes, omdat deze soorten een deel van hun leven (vooral 's nachts) doorbrengen in het zand. Om dit te testen, moeten in toekomstige studies 's nachts bodemmonsters verzameld moeten worden. De akoestische opstelling die in dit onderzoek is gebruikt, is geschikt het bestuderen van veranderingen in de verspreiding van pelagische soorten tijdens en kort na

zandsuppletieactiviteiten met als voorwaarde dat er geschikt vistuig beschikbaar is.

Tijdens het onderzoek werden zoöplanktonmonsters verzameld met een WP2 net met een maaswijdte van $200 \mu \mathrm{m}$. De vangsten werden gedomineerd door de dinoflagellate Noctiluca scillitans (zeevonk). De aantallen van deze soort in de monsters waren een orde van grootte hoger dan de som van alle andere waargenomen taxa. Behalve N. scillitans bestond zoöplankton voornamelijk uit Calanoida en in mindere mate uit Appendicularia, Cladocera, larven van Bivalvia en larven van Polychaeta. Deze bevindingen zijn in lijn met eerder onderzoek in de Belgische kustzone. 


\subsection{Ecological effects of sand nourishments}

In 2017 and 2018 the Dutch Ministry of Infrastructure and Water Management (In Dutch: Rijkswaterstaat; RWS), commissioned a survey along the Dutch coast to study the effects of sand nourishments, which are carried out on a regular basis to protect the coast against erosion (Mulder et al. 2011). A large part of these nourishments take place in an area - the Dutch North Sea Coastal Zone; "Noordzeekustzone" - which is protected under Natura2000 legislation. The objective of the study was to gain better understanding of the possible effects of the nourishments.

The survey that was carried out in 2017-2018 is part of the program "Natuurlijk Veilig" (NV) and focused on the effects of benthic fauna and juvenile fish in the surf zone (Baptist et al. 2017). While routine fish surveys in the coastal zone are normally carried out with beam trawl and focus on demersal fish, during the present survey also pelagic fish and zooplankton were included. This report presents the results from the acoustic - and zooplankton sampling during the survey.

\subsection{Pelagic fish along the Dutch coast}

Couperus et al. (2016) showed that biomass of small pelagic fish in the Dutch coastal zone is an order of magnitude higher than demersal fish. For a better understanding of the coastal ecosystem and the effect of large scale operations like sand nourishments it is important to include pelagic fish in ecological impact studies. Even while small pelagic fish species are not protected under nature conservation legislation such as Natura 2000, protected (bird and or marine mammal) species which depend on small pelagic fish as food may be affected

The sandy coast of the Netherlands is an important area for sandeel (two species: Ammodytes tobianus and $A$. marinus.) which spends part of its life buried in sand of specific coarseness (Tien et al. 2017, van Hal \& Volwater, 2019). In addition, the turbid coast is a nursery area for herring (Clupea harengus; Zijlstra 1972; Dickey-Collas et al. 2009), where herring occurs mixed with the clupeid sprat (Sprattus sprattus) and to a lesser extent with anchovy (Engraulis encrasicolus) and pilchard (Sardina pilchardus). Colony breeding sea birds along the Dutch coast, depend highly on small pelagic fish (Dänhardt and Becker 2011; Jennings et al. 2012; Stienen 2006) this dependency is even stronger during the period of chick-feeding. The distance the parent birds have to fly to and from the feeding ground as well as the size of the fish in relation to the size of the chicks are important variables to explain (or even predict) breeding success. For an assessment of direct and indirect effects of sand nourishments on the coastal fauna, it is therefore important to gain knowledge of the role of pelagic fish in the Dutch coastal ecosystem.

The hypothesised impact of sand nourishments on pelagic fish is 1) via the sediment, 2) turbidity. Sandeels spend part of their life buried in the sand. This group is likely to be affected directly as they depend on sand with specific coarseness (particle size).

Fish that spend their entire life in the water column are not expected to be affected directly by sand nourishments as they depend on food - plankton - in the water column rather than from the bottom. However, there may be indirect effects. Sand nourishment result in (temporal) changes in the water visibility which may lead to reduced protection against predators. Another effect may be that lower visibility may also result in lower feeding efficiency for visual feeding species.

The study of pelagic fish in shallow waters of the Dutch coast is new. The patchiness and the (scale of) spatial and temporal variability in distributions is not yet known. In addition, it is not known how environmental factors have an impact on this. An earlier study took place in a relatively deep inlet of the Wadden Sea between the main land and the Island of Texel in deeper water (Couperus et al, 2016). This study indicated that fish were migrating with the tidal current in and out of the area, but 
many questions remained unresolved. What does happen at the shallow coast next to this inlet? In the absence of an inlet: is the presence of pelagic fish also related to the tide?

There are also questions on the survey methods. Pelagic fish can be sampled by echo-integration. The method is described by Simmonds and MacLennan (2005): it is based on dividing the total surface of echo's (Nautical Area Scattering Coefficient: NASC, $\mathrm{m}^{2} / \mathrm{nm}^{2}$ ) which are assigned to a fish species, by the backscattering cross section of a single fish $\left(\sigma_{b s}\right)$ of mean length representative for the area. The backscatter cross section differs per species and can be found empirically from single target data in the survey area. By following this method, the density and biomass of targeted species can be estimated. However, this requires information on the composition of the schools which have been acoustically observed, (1) to identify the species and assign the NASC's and (2) to apply the correct mean lengths and weights of the fish. The way to obtain this information is by sampling these schools with a net that is held open by trawl doors and has a sufficient high opening. The available vessel for this study did not have the equipment for fishing with trawl doors. As a result, it is not possible to give accurate species composition and densities of pelagic fish species. However, the simultaneously use of acoustics and beam trawl, provides the opportunity to compare acoustic data with catches from the beam trawl. It is assumed that beam trawl used for the sampling of demersal fish does not provide relevant information on pelagic fish (E.g. Baptist et al. 2017). However, given the lack of pelagic sampling we investigated the correlation between acoustic signals and catches by a beam trawl to demonstrate that this assumption is correct.

The hydro acoustic method of echo integration is a well-known and much used technique in the deeper pelagic environment at depths to $15 \mathrm{~m}$ (Simmonds and Maclennan, 2005). If used in shallower water, the method may be hampered by the near field - the area under the transducer where the transmitted sound pulses cause unreliable measurements and effectively makes it part of the vertical range where it is not possible record fish schools. The other part of this so called "blind zone" is the depth of the transducer: the vertical range above the transducer is not covered. If fish schools are close to the surface - in the blind zone - they will not be recorded.

Another aspect of the use of vertical aimed hydro acoustic devices in shallow waters is the extent to which fish schools are missed because they escape from the approaching vessel before they can be detected.

Similar to pelagic fish, zooplankton off the coast of the Netherlands has been largely overlooked. There is no recent description of the zooplankton community in the area. The only studies that may be indicative for the Dutch coast have been carried out by Van Ginderdeuren (2014a \& 2014b) off the Belgium coast.

In the context of the uncertainties described above, the acoustic part of the survey was exploratory in nature with the focus on the following questions:

1. How variable in time and space is the distribution of pelagic fish along the coast?

2. Are the variations in distribution of pelagic fish correlated with tide and/or time of the day?

3. Can beam trawl catches be used as an index of pelagic fish in the sandy coastal zone of the Netherlands?

4. Do fish schools remain undetected due to escape from the vessel in the shallow environment of the coast? Although it was not the original objective of this study to investigate possible escape behaviour of pelagic fish, this topic will be briefly addressed.

5. The objective of the zooplankton sampling during the survey was to make a preliminary description of the zooplankton community during the survey as a reference for future research on diet of pelagic fish in the Dutch near coastal zone.

\subsection{Environmental conditions}

The water temperature in the area was typical between 17 and $18{ }^{\circ} \mathrm{C}$ at trawling depth. Under sunny conditions with low wind speeds the surface temperature were higher up to $21^{\circ} \mathrm{C}$. Secchi depths ranged between 1.0 and $1.5 \mathrm{~m}$. Turbidity was between 20 and 25 NTU. 
2 Methods

\section{$2.1 \quad$ Acoustic set up}

Echo location data were recorded with an EK60 and a $200 \mathrm{kHz}$ Simrad splitbeam transducer which was deployed on a depressor for stabilization and towed from a crane off the bow of the survey vessel (Figure 1). A towed body was towed out of the side by means of a Kevlar enforced electrical cable (Figure 2). Figure 3 gives an overview of the set up.

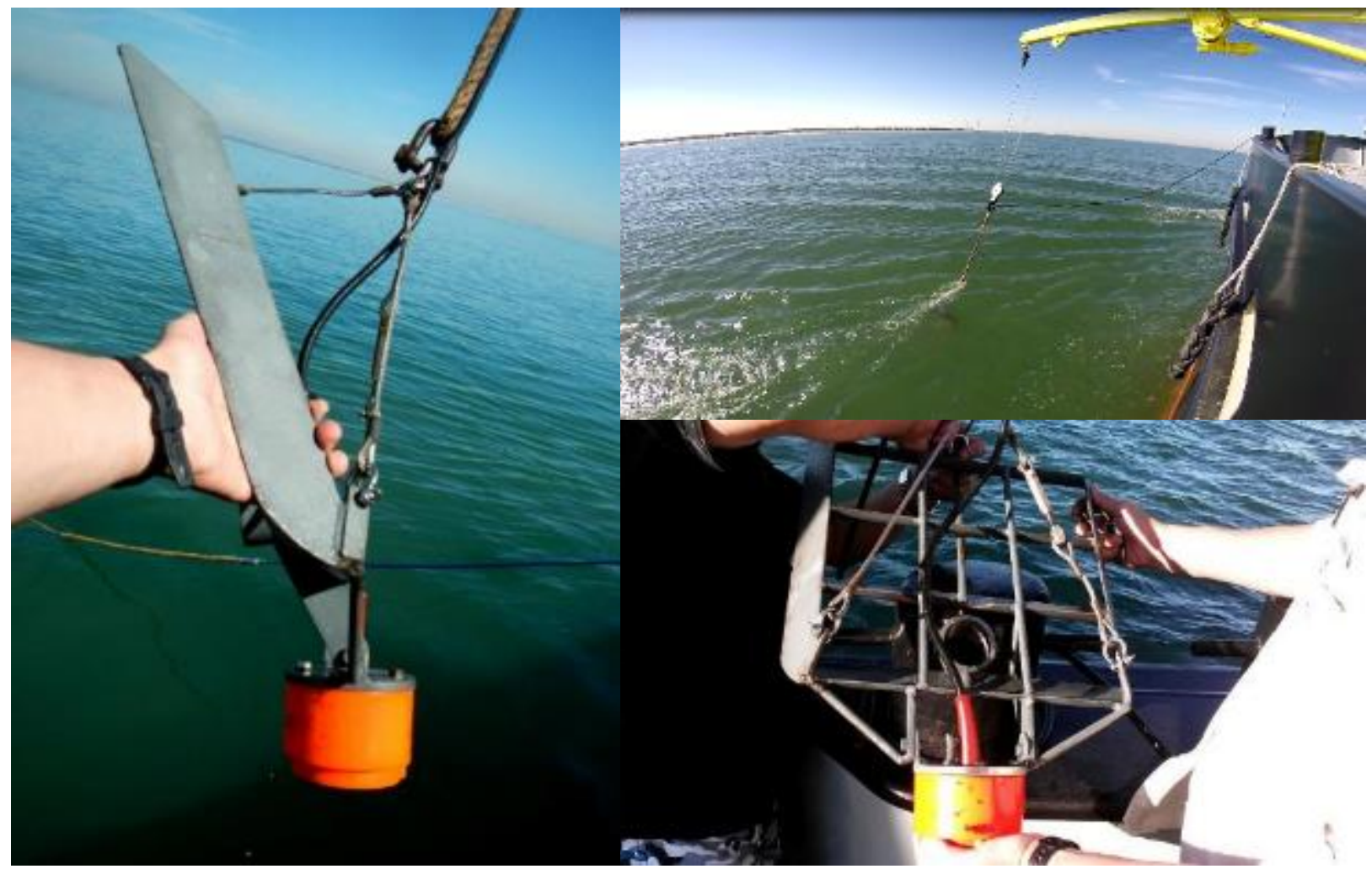

Figure 1. The Simrad splitbeam $200 \mathrm{kHz}$ transducer was deployed on a depressor which was towed from a crane approximately $1.5-2 \mathrm{~m}$ from off the bow of the survey vessel.

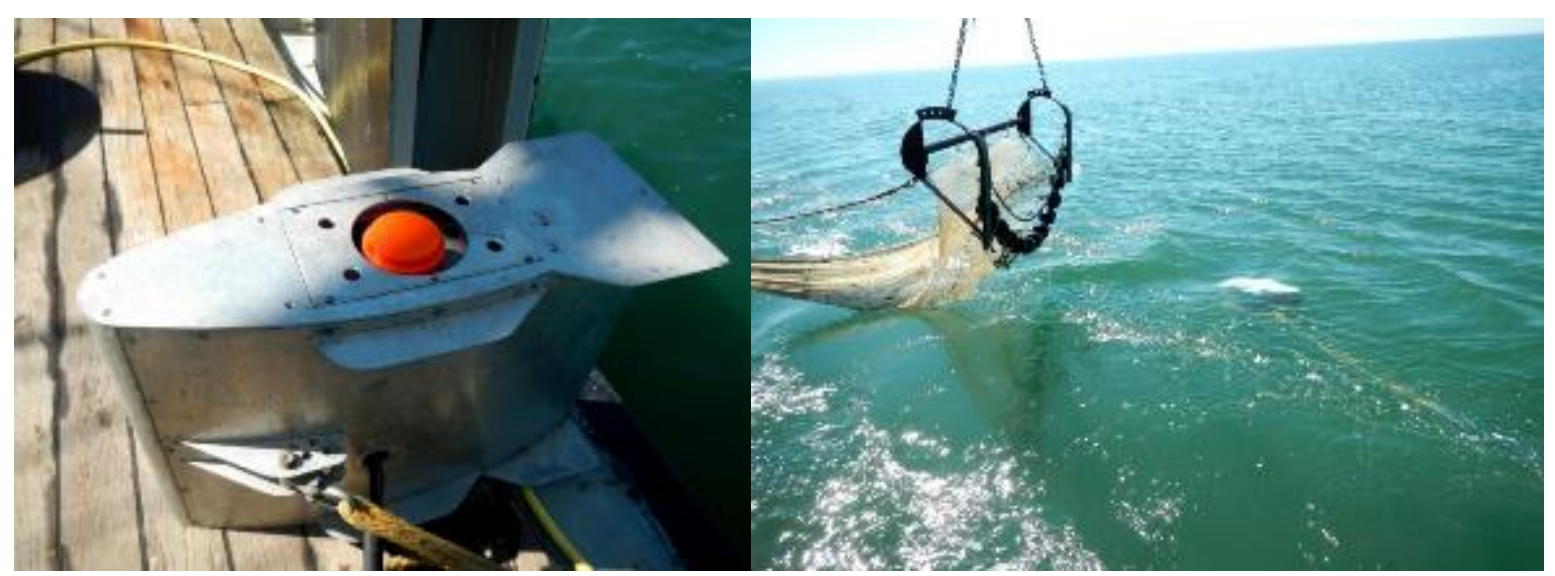

Figure 2. A second Simrad splitbeam $200 \mathrm{kHz}$ transducer was deployed in a towed body which was towed from the side and sheared out from the survey vessel. The towed body in the left picture is placed upside down with view on the transducer. The right picture shows the towed body in the water when towed. 


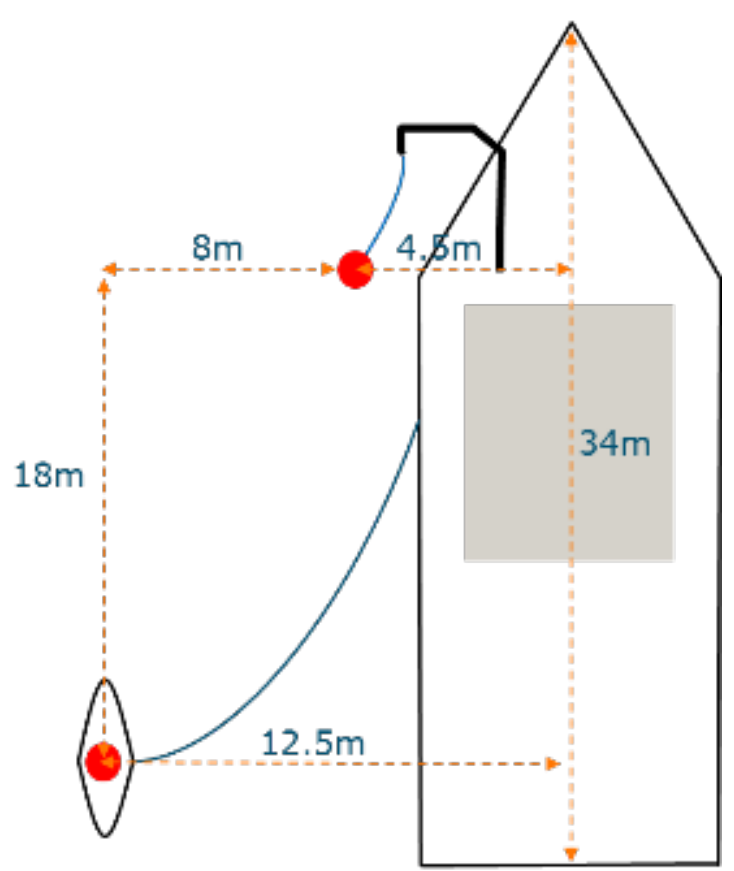

Figure 3. Set up with the transducers (red dots) deployed in the depressor at the front and in the towed body at the side of the of the vessel.

Both transducers were operated during the trawl stations. In addition the depressor deployed transducer was operated as much as possible depending on the situation (safety and other measurements). Technically this was not possible for the towed body because operation of this device was limited ocassions with a speed range of 0.1 to 3 knots. The pulse interval was set to maximum and the pulse length was $0.064 \mathrm{~s}$. The acoustic system was calibrated halfway the survey at Lauwersoog. This resulted in a correction factor which was applied for the analysis of the raw acoustic data. The TS transducer gain and the Sa-correction were applied afterwards during post processing. Post processing was carried out with Echoview Software. Sections with air bubbles blocking the transmitting pulses were removed from the data set. A school detection algorithm in Echoview was applied to assign echoes to fish. All files were re-scrutinized manually afterwards to clean the echograms from noise and wrongly detected schools and assign fish to schools that were missed by the algorithm. Nautical Area Scattering Coefficients (NASC's) were exported per $100 \mathrm{~m}$ interval with geographical positions. Further analysis was carried out in R and MS Excel.

\subsection{Variability in distribution biomass estimation}

Acoustic measurements took place according to the methods described in Baptist et al (2017). Sampling locations were predifined along transects in three different locations (Dutch: "kustvakken") Zuid-Holland, Noord-Holland and Texel in 2017 and Schiermonnikoog (Annex 1).

Acoustic data were collected during tows of 5 minutes with the beam trawl at a speed 2-3 knots. In addition, in 2017 data was collected on the tracks between stations with varying speeds in the range of $1-4$ knots.

Length distributions of herring and sprat were determined from the beam trawl hauls. From the length distributions the mean acoustic backscattering cross-section ( $\left.\sigma_{b s}\right)$ was calculated. First the 'Target Strength' (TS) - length relationship (Simmonds and MacLennan, 2005) was applied using

TS $=20 \log _{10}[$ mean fish length $]+b_{20}$

In the absence of a readily available TS relationship for herring and sprat for $200 \mathrm{kHz}, \mathrm{b}_{20}$ was derived from multi frequency data in the ICES coordinated Herring Acoustic Survey 2018 (Annex 2):

TS $=20 \log _{10}[$ mean fish length $]-74.25$ 
Subsequently, the mean acoustic backscattering cross-section ( $\sigma_{b s}$ ) was calculated using the target strength, again following (Simmonds and MacLennan, 2005):

$\sigma_{\mathrm{bs}}=10^{\mathrm{TS}} / 10$

The densities of clupeids were calculated by dividing NASC by $4 \pi \sigma_{b s}$. The mean weight of all clupeids in the catches was calculated by applying the length $(\mathrm{cm})$ - wet weight $(\mathrm{g})$ relationship $\left(\mathrm{W}=\mathrm{aL}^{\mathrm{b}}\right)$ previously measured for herring and sprat off the Dutch coast in the second quarter (Grift et al. 2004): $a=0.008$ and $b=2.928$ for herring; $a=0.0058$ and $b=2.850$ for sprat. Pelagic fish biomass was estimated by multiplying estimated fish densities with the surface area between the inner and the outer sample locations of each coastal area, being $2.83 \mathrm{nmi}^{2}$ (970.88 ha) for the Zandmotor, 7.39 $\mathrm{nmi}^{2}$ (2537.79 ha) for Noord-Holland and $18.15 \mathrm{nmi}^{2}$ (6231.62 ha) for Texel and $15.61 \mathrm{nmi}^{2}$ (5354.08 ha) for Schiermonnikoog.

\subsection{Comparison with beam trawl}

For a comparison of the NASC's with the $3 \mathrm{~m}$ beam trawl catch $100 \mathrm{~m}$ intervals were selected of which the midpoint fell in the track covered during towing. Numbers of pelagic fish per trawl station were obtained from the beam trawl sampling (Van Hal et al, 2017). Since herring and sprat dominated the catches of the $3 \mathrm{~m}$ beam trawl and were present in 73\% (30 out of 41 ) of the hauls, we assume that the recorded schools mainly consisted of these species.

\subsection{Impact of depth, time of the day and tidal phase}

Variability of acoustic intensities due to tidal phase and time of the day was investigated by applying a Generalised Additive Model (GAM) including location, depth, time of the day and the tidal phase. The advantage of using a generalised model (e.g. GLM) is the flexibility of assuming different statistical distributions for the error (e.g. Poisson, binomial or gamma distributions) while allowing for nonlinearity in the data by fitting smooth functions, which improves the explanatory success. Information on depth, time and location was taken from the acoustic dataset. For the tidal data, the modelled sea surface height (with 10-minute intervals) relative to the mean sea level were used (from Rijkswaterstaat, www.waterinfo.rws.nl). The tidal state differs per location along the coast. Figure 4 illustrates this for three stations that are used for the tidal model (Texel Noordzee, IJmuiden and Hoek van Holland). For the analysis tidal RWS stations that are closest to the acoustic/beam-trawl sampling stations were selected and merged according to time with the acoustic recordings collected during the beam-trawl sections. The acoustic data points of the one-minute intervals were averaged per beam trawl station. The data initially exported by one-minute interval resulted in 262 data points which were then averaged per beam-trawl station, resulting in 36 data points.

\subsection{Possible escape behaviour of fish}

The transducer mounted in the depressor and the towed body were operated during the trawls. If fish schools show avoidance behaviour and swim away from the approaching vessel, the expectation is that the towed body, which is shearing out from the vessel, detects significantly more fish in comparison to the transducer towed at the bow of the vessel. NASC's of simultaneous acoustic intervals were grouped by $10 \mathrm{log}$ NASC class for comparison. 


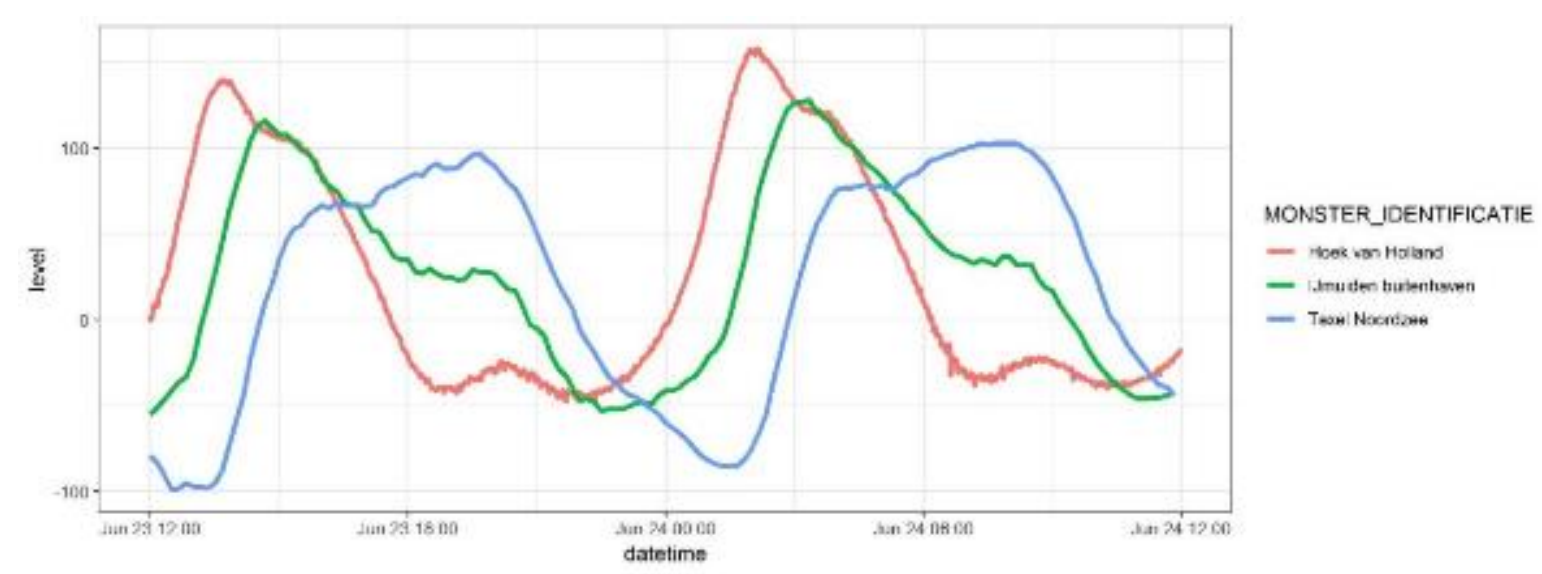

Figure 4. Example of predicted sea surface heights from three locations from the tidal model used by Rijkswaterstaat (www.waterinfo.rws.nI).

\subsection{Zooplankton sampling}

Zooplankton samples were collected with a WP2 net (200 $\mu \mathrm{m}$ mesh, $57 \mathrm{~cm}$ ring diameter) as vertical tows from bottom to surface (10-12 m.) at the offshore-end station of each transect (station numbers $* * 7$ ). From this sample set, seven samples from the five different areas were analysed in detail for the taxonomic compositions, four areas from the year 2017 and one area from 2018. For the 2017 samples, the taxonomic identification was done up to the genus level when possible and family level in 2018. Identification and counting was carried out in subsets of the samples with subsampling ratios changing between $1 / 32$ and 1/64 depending on the densities. Subsampling was done with a Folsom plankton splitter. All subsets were scanned using an optical flatbed scanner in shadowgraph mode (i.e. light from the top, imaging from the bottom) using an acryl transparent container. Before splitting, whole samples were carefully examined for the presence of large or rare specimens which were then processed separately as they would unlikely end up in the subsamples in representative proportions. Detailed analysis for 2017 was carried out in the laboratory using an optical microscope and for 2018 analysis was carried out only using the scanned images. In addition, the counting of Noctiluca scintillans specimens was performed for both 2017 and 2018 from the scanned images. 


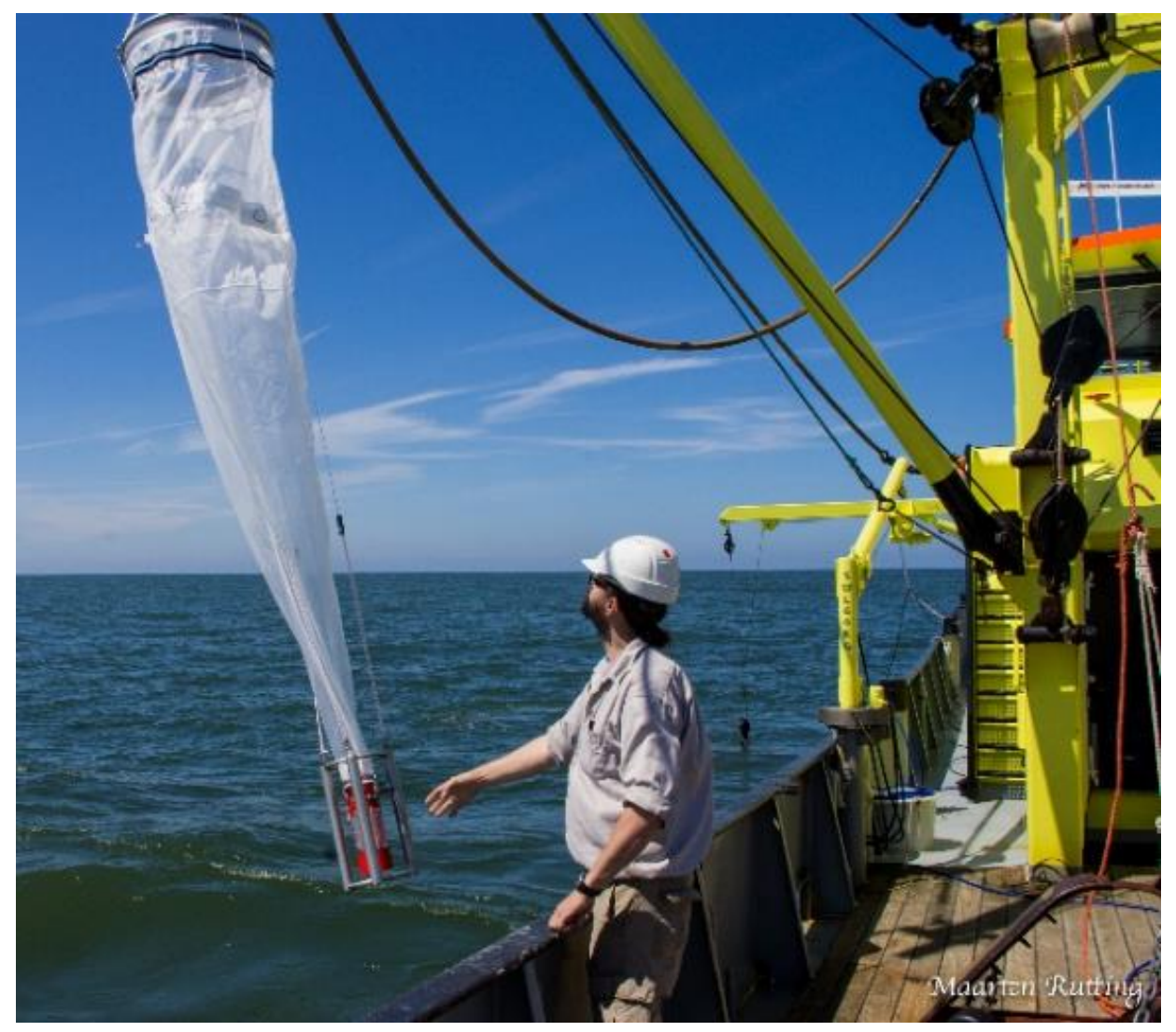

Figure 9. Operation of the WP2 plankton sampling net during the preceding experimental survey in 2016.

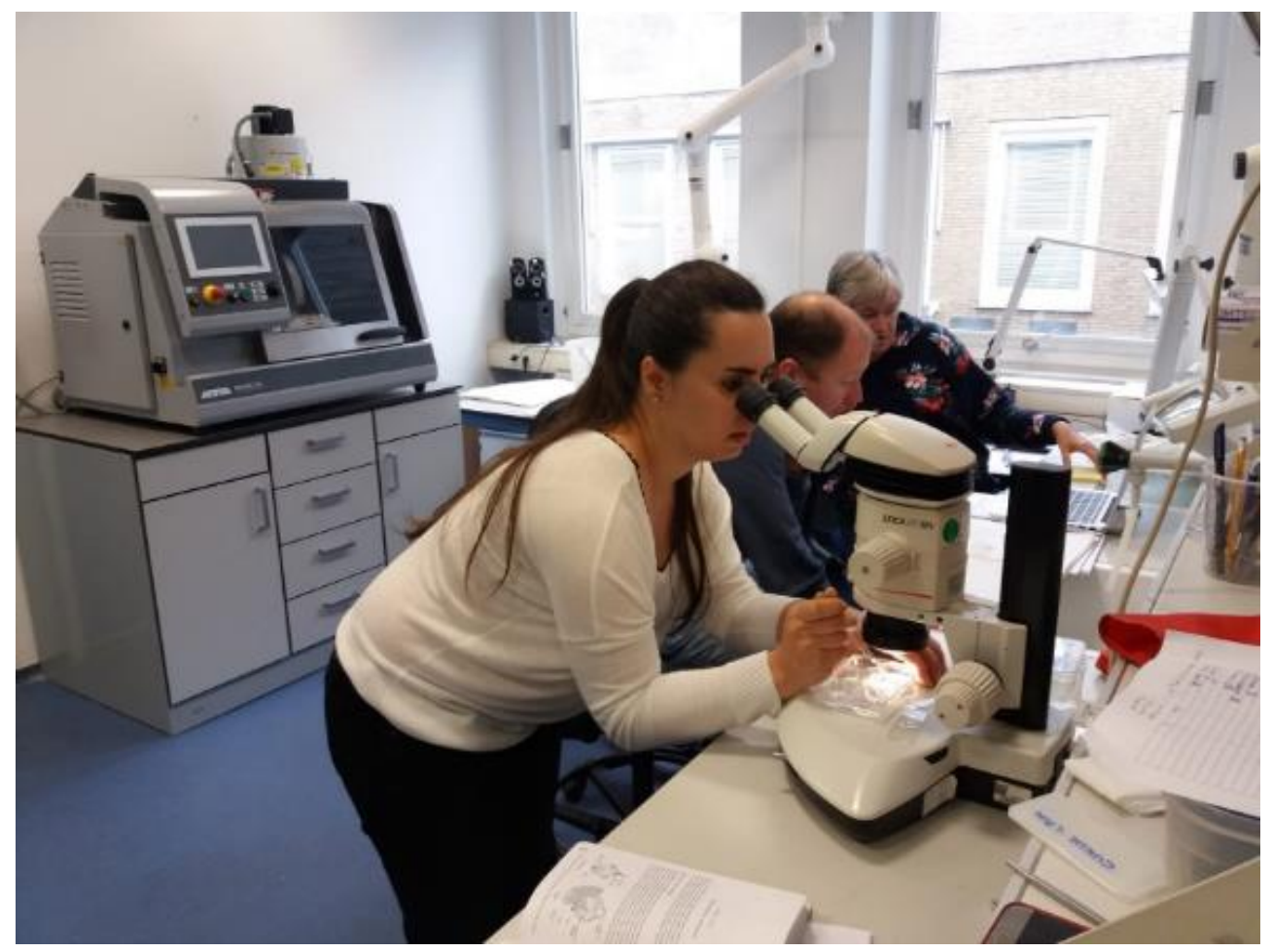

Figure 5. Analysis of the plankton samples in the lab of Wageningen Marine Research in IJmuiden. 


\subsection{Distribution at the coastal locations}

Figure 6 is an example of a typical echogram as seen during the survey. Figure 7 and 8 show boxplots of log transformed NASC's per location. The NASC's have been expressed as log transformed values because of the high variability in the values. The figures show large variations between the acoustic sampling units. The overall differences in densities between the areas are not significant.

Table 1 and 2 show the number of acoustic sampling units of $100 \mathrm{~m}$ with the median and mean NASC's. Table 2 shows data for the tracks of the $3 \mathrm{~m}$ beam trawl stations including the sailed sections between the sampling stations. Table 1 shows only data for the tracks of the $3 \mathrm{~m}$ beam trawl stations. Annex 4 provides the NASC values of the $100 \mathrm{~m}$ units of the beam trawl stations including the sailed sections between the stations as coloured dots projected on a satellite map. The last two figures in Annex 4 provide an overview of the acoustic tracks in 2017 and 2018 respectively.

Under the assumption that all recorded schools can be assigned to clupeids (i.e. herring or sprat), the average density of all survey days in 2017 is $123 \mathrm{~kg} / \mathrm{ha}$ for the fish tracks only and $126 \mathrm{~kg} / \mathrm{ha}$ including the inter station tracks. The mean for 2018 at Schiermonnikoog is $4 \mathrm{~kg} / \mathrm{ha}$. The mean densities for the separate coastal areas in 2017 are (densities excluding the inter station tracks between brackets) 40 (29) kg/ha for Zuid-Holland, 195 (209) kg/ha for Noord-Holland and 120 (79) kg/ha for Texel. The density in 2018 at Schiermonnikoog was $4 \mathrm{~kg} / \mathrm{ha}$. Annex 5 provides an example of these arrays of schools.

The mean density of all survey days in 2017 and 2018 including the tracks between the stations is 98 $\mathrm{kg} / \mathrm{ha}$.

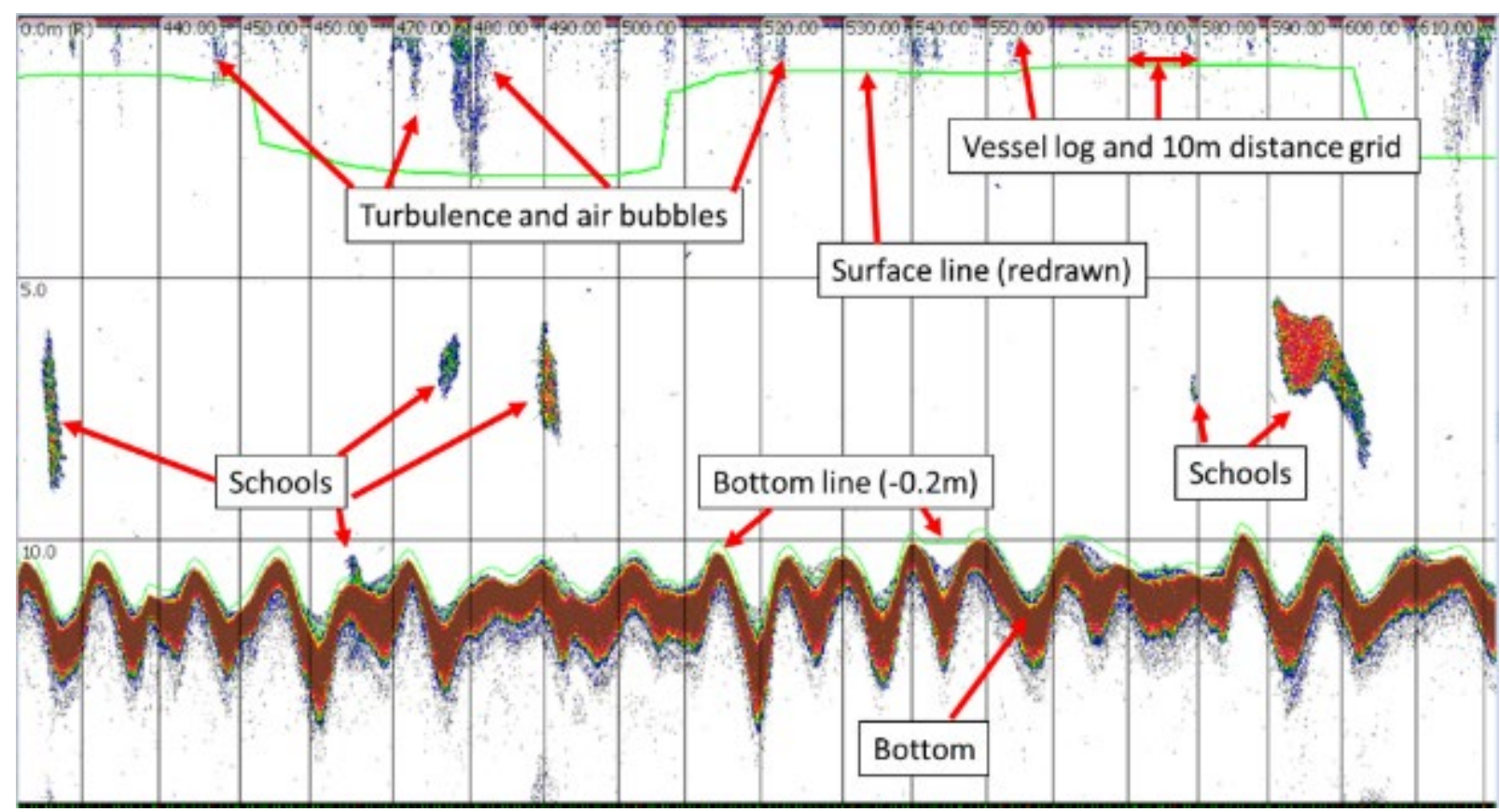

Figure 6. A typical echogram during the survey (Sv threshold $-51 \mathrm{~dB}$ ). The bottom is undulating due to the movements of the vessel. The surface - and bottom lines (green) are redrawn to exclude noise (e.g. air bubbles and parts of the bottom that have not been detected as such, due to reflection of pulses at a low angle). 
Table 1 Number of acoustic sampling units of $100 \mathrm{~m}$ with the Nautical Area Scattering Coefficients (NASC, $\left.\mathrm{m}^{2} / \mathrm{nm}^{2}\right)$, including the sailed tracks between sampling stations. *Based on the surface between the inner and outer sampling positions at the locations.

\begin{tabular}{|c|c|c|c|c|c|}
\hline Location & Date & $\begin{array}{l}\text { Mean } \\
\text { (NASC) }\end{array}$ & $\begin{array}{l}\text { Median } \\
\text { (NASC) }\end{array}$ & $\begin{array}{l}\text { No of } \\
\text { sampling } \\
\text { units of } \\
100 \mathrm{~m}\end{array}$ & $\begin{array}{l}\text { Area } \\
(\mathrm{ha})^{*}\end{array}$ \\
\hline Z-Holland & 20170613 & 638.6 & 257.2 & 43 & 970.88 \\
\hline Z-Holland & 20170614 & 1206.0 & 147.3 & 105 & 970.88 \\
\hline Z-Holland & 20170615 & 1047.7 & 58.5 & 61 & 970.88 \\
\hline N-Holland & 20170619 & 6927.1 & 1843.4 & 128 & 2537.79 \\
\hline N-Holland & 20170620 & 180.1 & 19.1 & 28 & 2537.79 \\
\hline $\mathrm{N}-\mathrm{Holland}$ & 20170621 & 7493.2 & 425.6 & 53 & 2537.79 \\
\hline N-Holland & 20170622 & 9939.6 & 704.6 & 42 & 2537.79 \\
\hline Texel & 20170626 & 2218.1 & 993.4 & 17 & 6231.62 \\
\hline Texel & 20170627 & 979.3 & 192.4 & 322 & 6231.62 \\
\hline Texel & 20170629 & 1587.0 & 202.2 & 296 & 6231.62 \\
\hline Schiermonnikoog & 20180618 & 932.4 & 18.9 & 35 & 5361.0 \\
\hline Schiermonnikoog & 20180619 & 356.7 & 0 & 106 & 5361.0 \\
\hline Schiermonnikoog & 20180620 & 1272.2 & 48.1 & 25 & 5361.0 \\
\hline
\end{tabular}

Table 2 Number of acoustic sampling units of $100 \mathrm{~m}$ with the Nautical Area Scattering Coefficients (NASC, m2/nm2) by survey day, excluding the sailed track between sampling stations. *Based on the surface between the outer sampling positions.

\begin{tabular}{llllll} 
& & \multicolumn{5}{c}{$\begin{array}{l}\text { No of } \\
\text { sampling }\end{array}$} \\
Location & Date & $\begin{array}{l}\text { Mean } \\
\text { (NASC) }\end{array}$ & $\begin{array}{l}\text { Median } \\
\text { (NASC) }\end{array}$ & $\begin{array}{l}\text { of 100m } \\
\text { area } \\
\text { (ha) }^{*}\end{array}$ \\
\hline Zandmotor & 20170614 & 488.7534 & 39 & 41 & 970.9 \\
Zandmotor & 20170615 & 723.6923 & 182 & 6 & 970.9 \\
N-Holland & 20170619 & 875.4516 & 102.5 & 23 & 2537.8 \\
N-Holland & 20170620 & 14.61194 & 546 & 13 & 2537.8 \\
N-Holland & 20170621 & 6327.8 & 11 & 13 & 2537.8 \\
N-Holland & 20170622 & 709.1111 & 2767 & 11 & 2537.8 \\
Texel & 20170627 & 579.3091 & 732 & 48 & 6231.6 \\
Texel & 20170629 & 853.486 & 173.5 & 47 & 6231.6 \\
Schiermonnikoog & 20180618 & 932.4 & 18.9 & 35 & 5361.0 \\
Schiermonnikoog & 20180619 & 356.7 & 0 & 106 & 5361.0 \\
Schiermonnikoog & 20180620 & 1272.2 & 48.1 & 25 & 5361.0
\end{tabular}




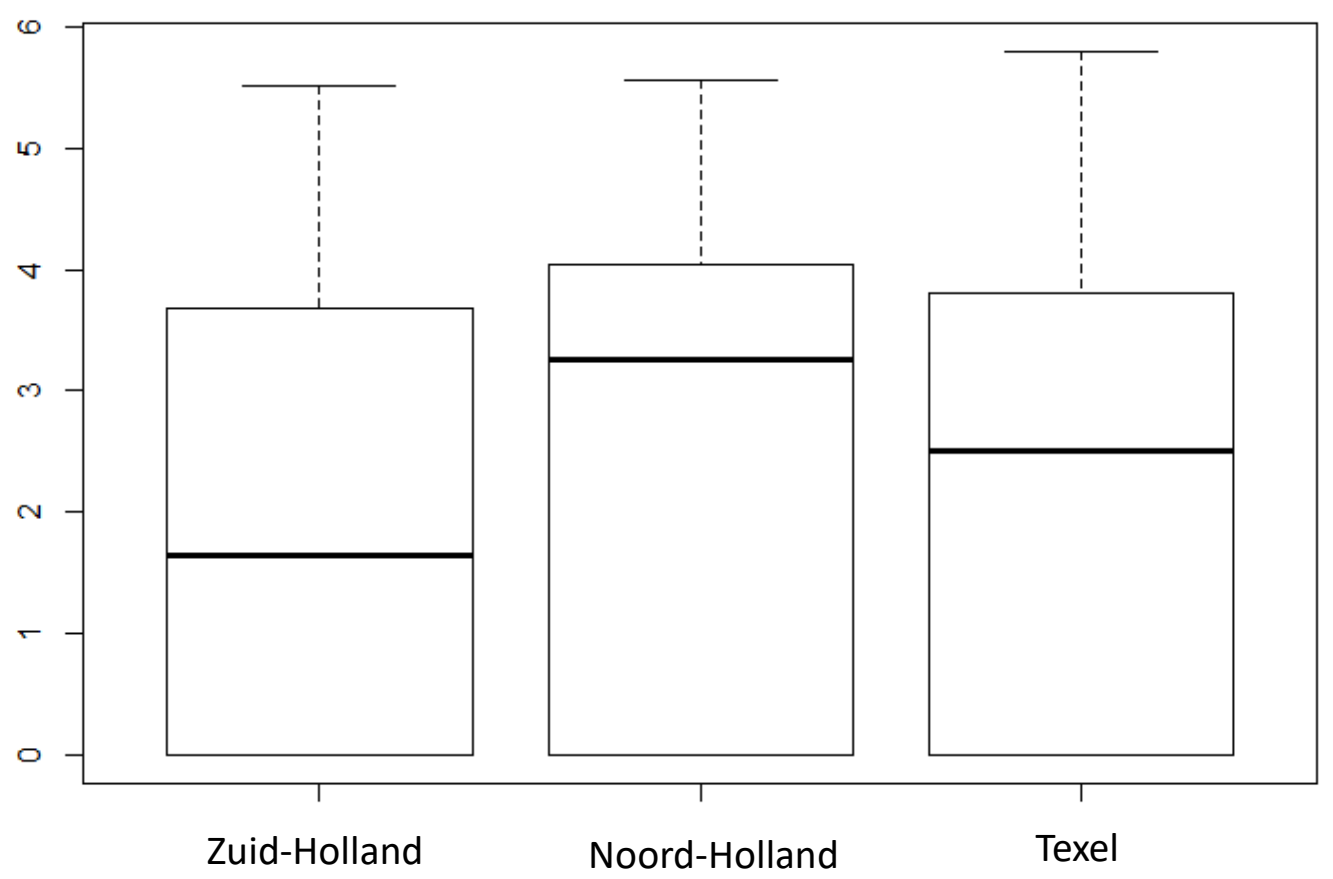

Figure 7. Boxplot of Log transformed NASC's per location (Zuid-Holland, Noord-Holland, Texel) in 2017.

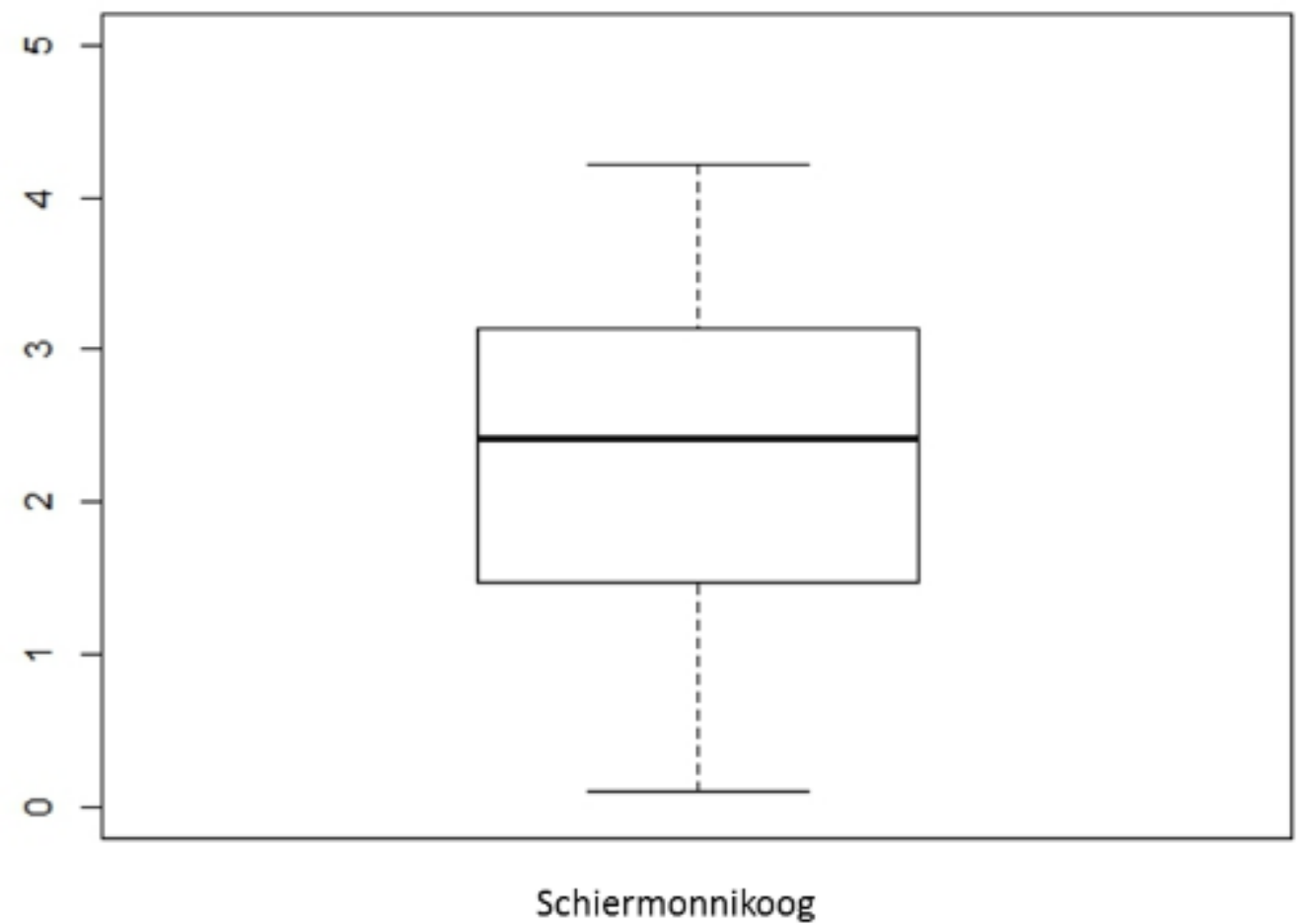

Figure 8. Boxplot of Log transformed NASC's per survey day in 2018 (Schiermonnikoog). 


\subsection{Comparison of acoustics with the beam trawl results}

The preliminary results from the fishing with the $3 \mathrm{~m}$ beam trawl (Annex 3 ) shows that herring - a pelagic fish species! - is by far the most frequently caught species. The acoustic data collected during fishing with the $3 \mathrm{~m}$ beam trawl can be compared with catch. Figure 10 gives the number of pelagic fish (sandeel, herring and sprat) for every trawl station and the concurring mean NASC. The catches show high numbers of pelagic fish for Zuid-Holland (sampled 13-15 June 2017). Whereas the acoustic data show several peaks evenly spread over the three areas. In figure 11 and 12 the catch (number of pelagic fish) is plotted against the Log10 of the NASC's. The plots suggest that there is no correlation between the two. For the higher NASC's there may even be a negative correlation with the catch and the NASC. 
NASC versus catch $3 \mathrm{~m}$ beamtrawl
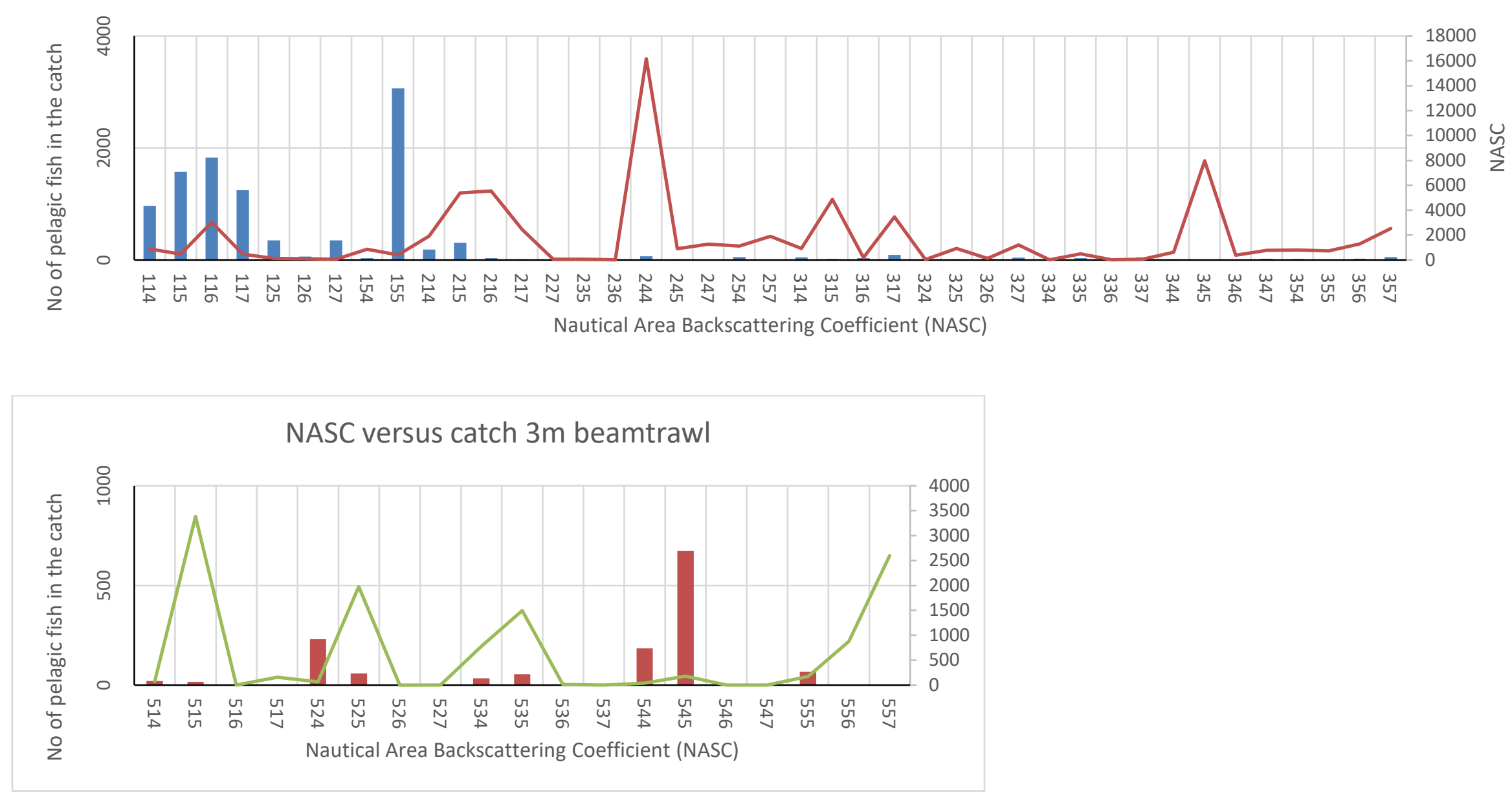

Figure 10. Number of pelagic fish (herring, sprat and sandeel) by $3 \mathrm{~m}$ beam trawl location and the mean Nautical Area Backscattering Coefficients (NASC) assigned to schools during the hauls in 2017 (upper) and 2018 (lower). Locations: 114-115=Zuid-Holland, 214-257=Noord-Holland, 314-356=Texel, 514557=Schiermonnikoog. 


\section{NASC versus catch $3 m$ beamtrawl}

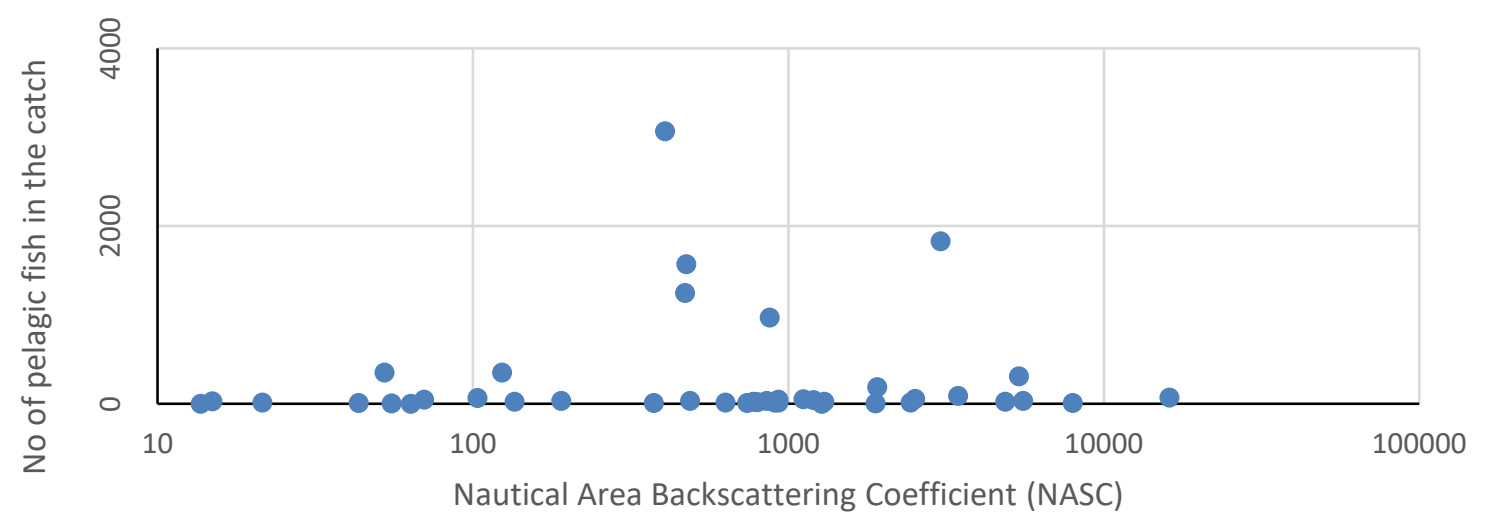

Figure 11. Number of pelagic fish (herring, sprat and sandeel) per haul plotted against the 10 Log of the Nautical Area Backscattering Coefficients of the $100 \mathrm{~m}$ intervals that were covered during the tow (Survey 2017). There is no correlation between these two.

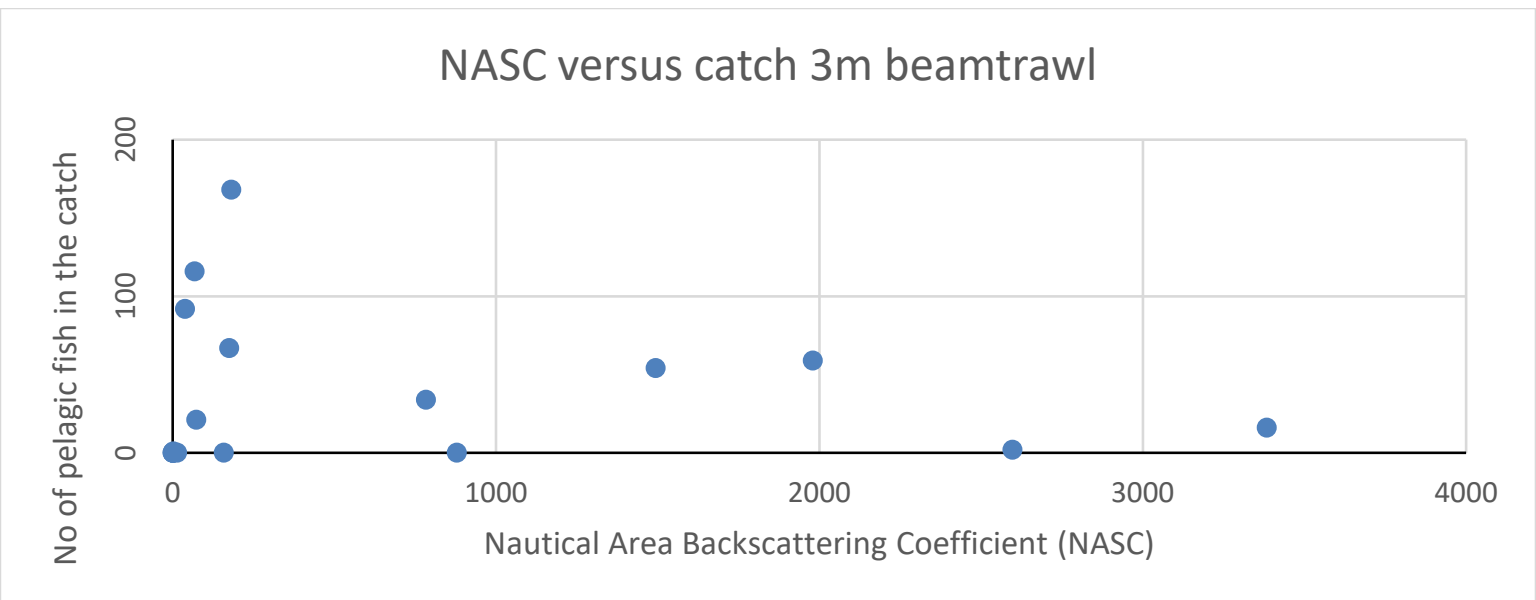

Figure 12. Number of pelagic fish (herring, sprat and sandeel) per haul plotted against the $10 \mathrm{Log}$ of the Nautical Area Backscattering Coefficients of the $100 \mathrm{~m}$ intervals that were covered during the tow (Survey 2018).

\subsection{Possible escape behaviour}

In total 110 simultaneous acoustic intervals or $100 \mathrm{~m}$ of the bow-transducer and the towed body were collected. The mean NASC was $808 \mathrm{~m}^{2} / \mathrm{nmi}^{2}$ for the towed body and $1510 \mathrm{~m}^{2} / \mathrm{nmi}^{2}$ for the transducer mounted in the depressor at the bow. In 44 intervals (towed body) and 33 (bow) no fish schools were recorded. Figure 13 presents the distribution by 10 log NASC classes. As expected (paragraph 3.1) the variation in recorded NASC's between de the sampling units is large in both the towed body and at the bow. The difference between the two methods is not significant (Figure 14). 


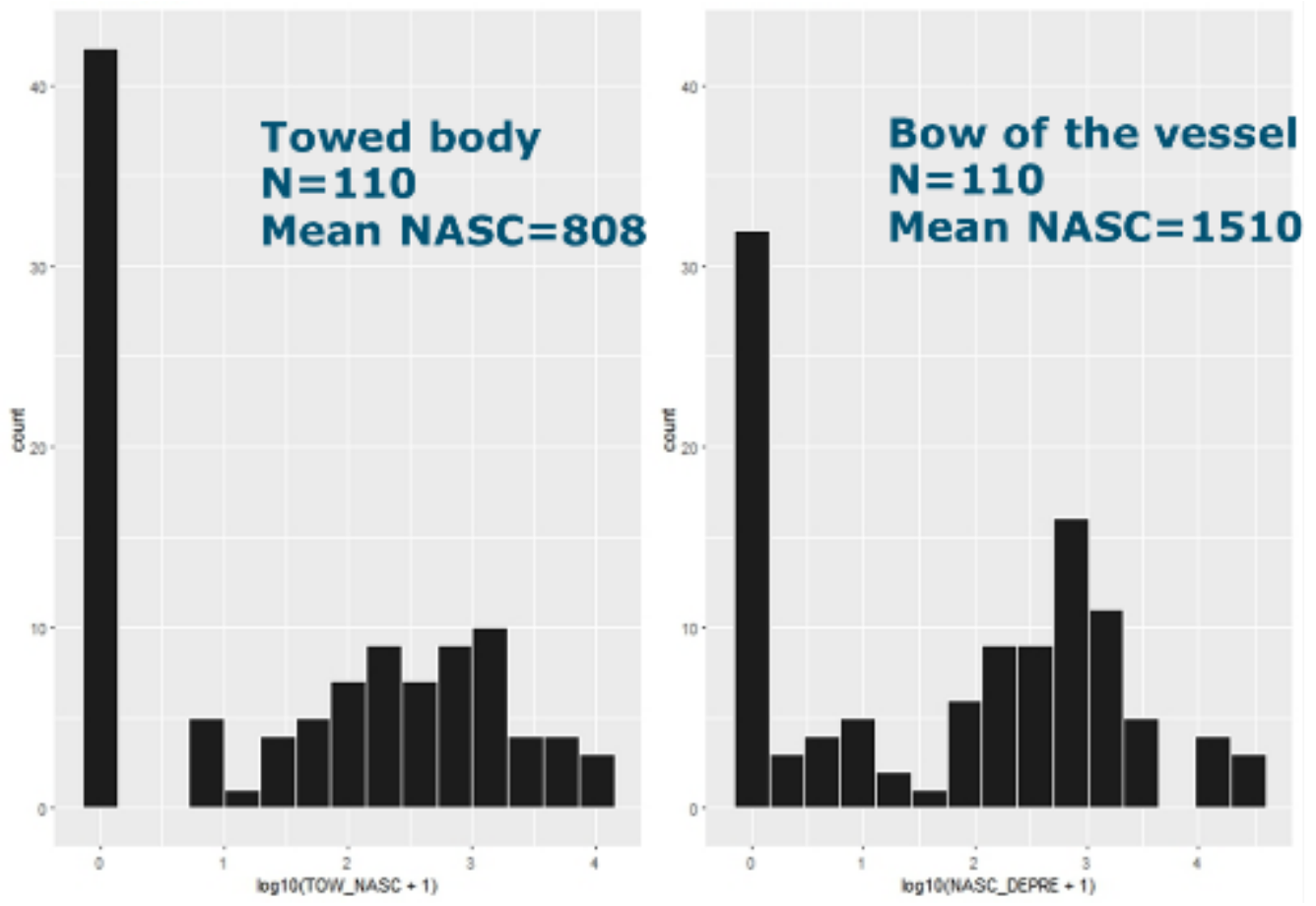

Figure 13. Distribution of $10 \mathrm{Log}$ NASC classes of the $100 \mathrm{~m}$ acoustic intervals $(n=110)$ recorded by the transducer mounted in the towed body and the transducer at the bow of the vessel.

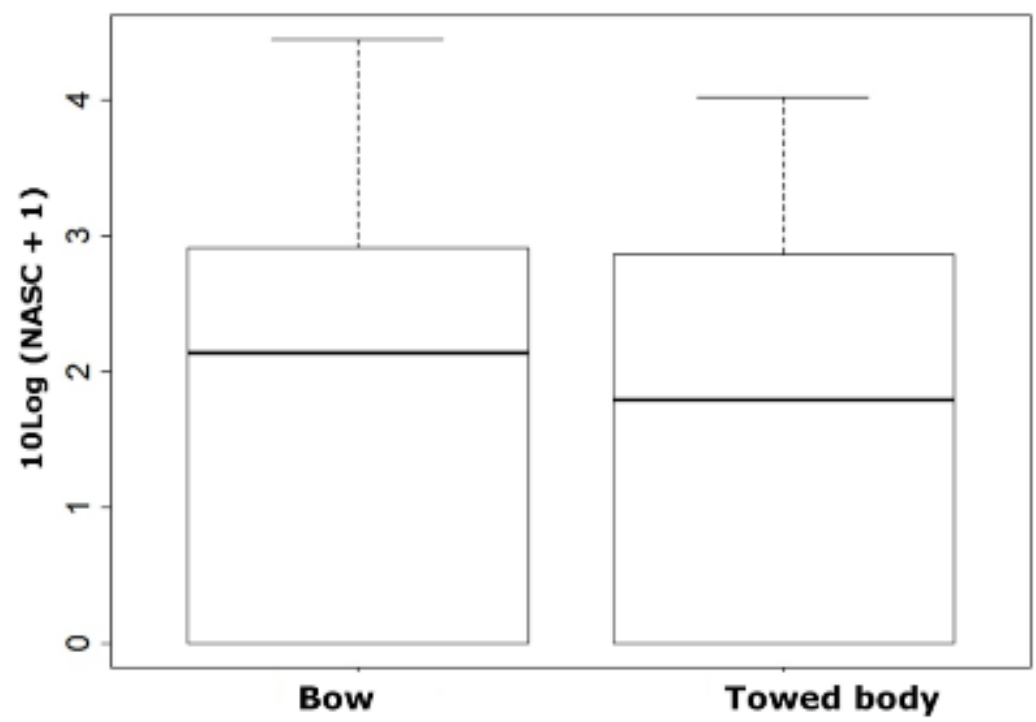

Figure 14. Boxplot of $10 \mathrm{Log}(\mathrm{NASC}+1)$ values recorded during simultaneous acoustic intervals $(n=110)$.

\subsection{Impact of tidal phase, time of the day and depth}

Figure 15 show the acoustically recorded fish densities (NASC's) in relation to the tidal phase. The graphs do not suggest any correlation the two. 

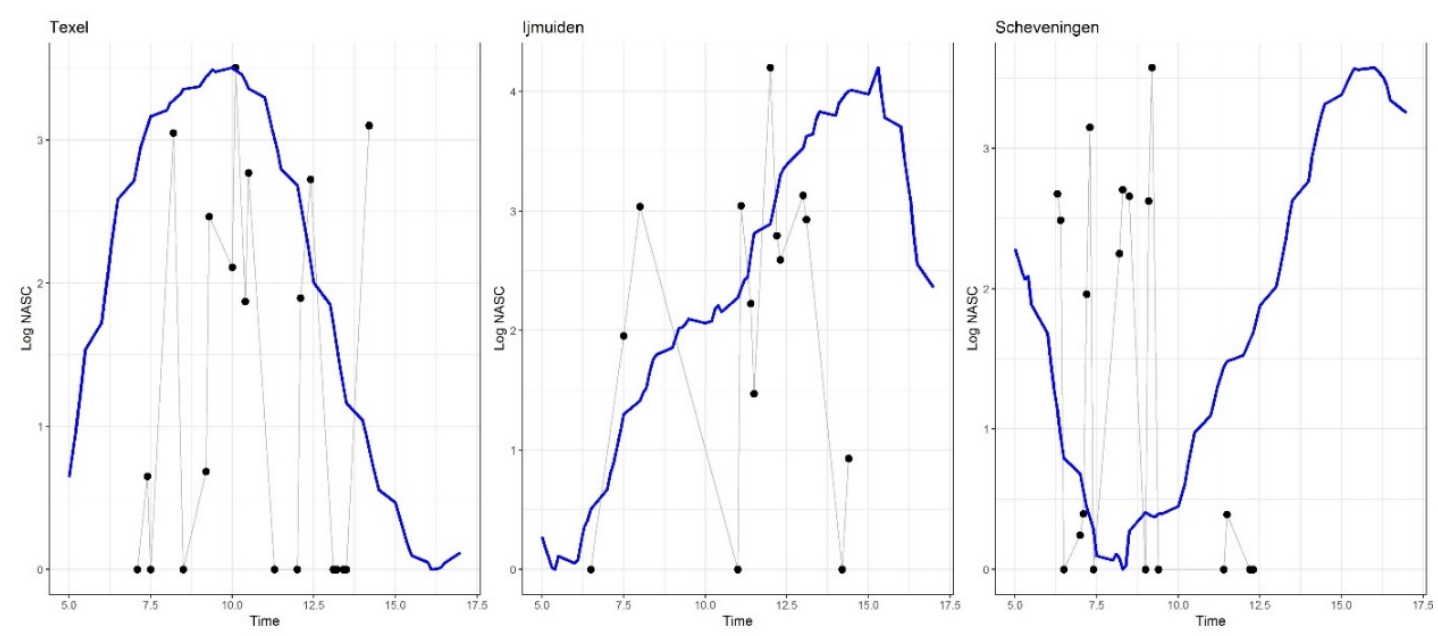

Figure 15. Tidal phase (blue line) and fish numerical intensity (Log NASC) relative to the time.
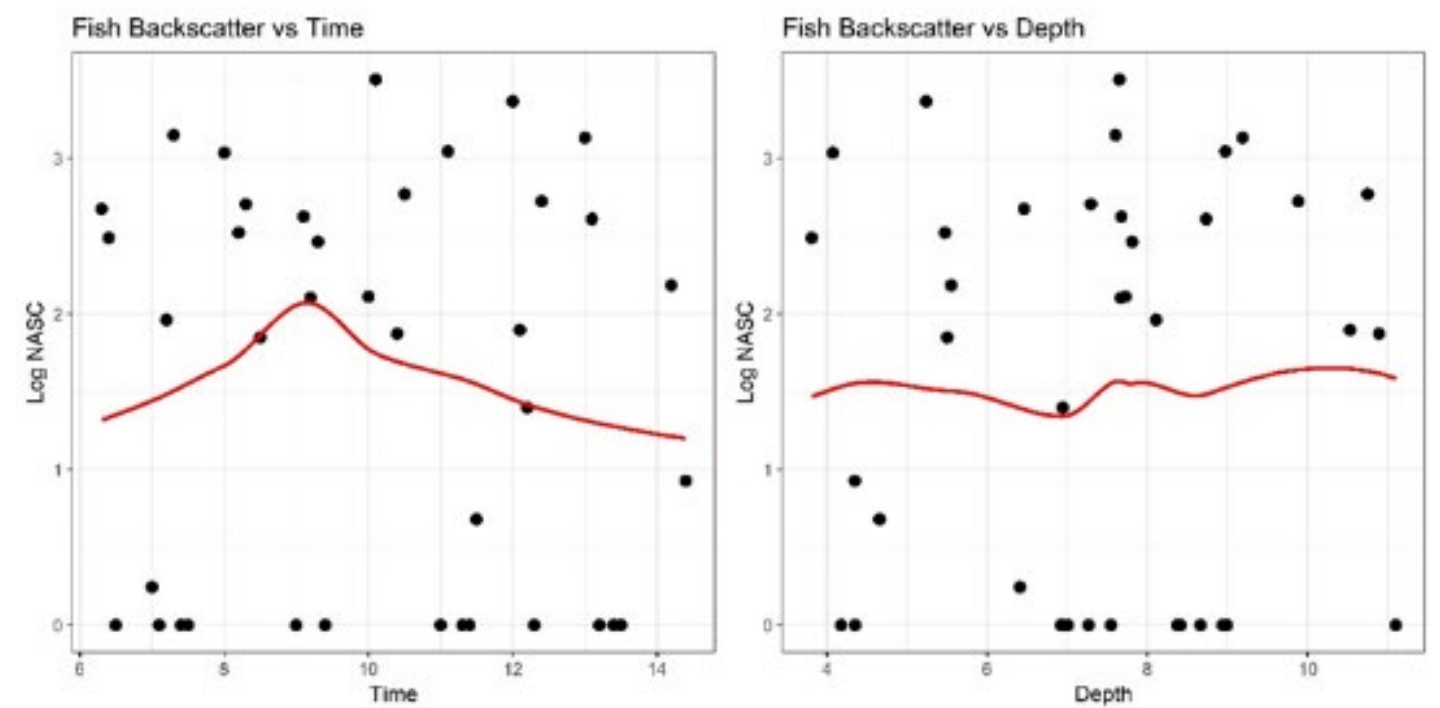

Figure 16. Fish backscatter relative to time of the day (left panel) and depth (right panel). The red curve is a smooth function fit to the data using LOESS technique.

Figure 16 (left) suggests that higher fish concentrations are observed towards the mid-day, but the influence of the time of the day on the fish distribution is not strong. Depth seems to have no visible effect (Figure 16, right).

Figure 17 give an impression how pelagic fish is distributed along the coast. Despite the high number of observed fish schools per sampled interval in the study area, the percentage of the zero-value observations were also relatively high, in Noord-Holland less than in the other two regions.

Furthermore, the distribution is highly dispersed with the variance of observations being substantially greater than the mean acoustic densities. 

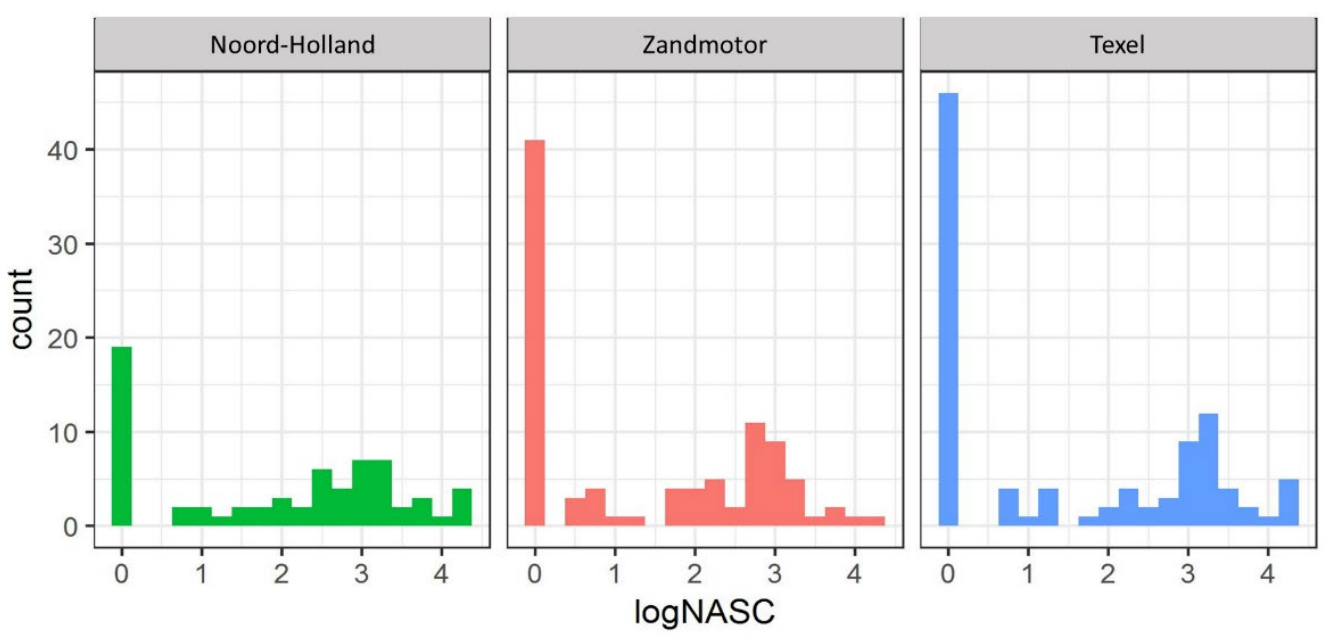

Figure 17. Distribution of observed acoustic backscatter in log scale per sampling interval. The variability of the fish densities is high in the three regions of Noord-Holland, Zandmotor, and Texel. The overall distribution of pelagic fish is dispersed, while most sampling intervals did not show any fish.

The percentage of the explained variability in the GAM model is low (The summary results of the GAM model are provided in Annex 6: deviance explained $=16.9 \%$ ). None of explanatory variables, tide, time of the day or depth had a significant effect in explaining the variability. In terms of the categorical variable, the location, Scheveningen was significantly different from the other regions.

\subsection{Zooplankton}

Noctiluca scintillans is by far the most dominant species in all stations indicating an intense bloom of the species for this period (10 to 50 times greater abundance than the sum of all other taxa; Table 3). Because of their extremely high numbers, they are separately represented in different plots below. Figure 19 shows the abundances of $N$. scintillans. 20 shows the numerical taxonomic composition as number of individuals per $\mathrm{m}^{-3}$ for 2017 where the calanoid copepods are the most dominant group in all stations when N. scintillans is excluded. In addition, Appendicularia, Cladocera, larvae of Bivalvia and larvae of Polychaeta are the common contributors to the total abundance in all stations. In the location of $Z$-Holland echinoderm larvae is one of the most abundant component of the assemblage while remaining low in other stations. In $\mathrm{N}$-Holland and Texel regions, Cirripedia makes a major contribution. In figure 21 these groups are presented broken down into genus level. The genus Temora, Centropages, Acarcia and Paracalanus are the main components of the calanoid group. Figure 22 provides an example of a scan of processed samples.

Preliminary scrutiny of the WP2 sample from 2018 based on the high-resolution scans seems to indicate that the results are in line with the samples from 2017 where the $N$. scintillans is the dominant taxon followed by the calanoids (Figure 23 and Table 3 ). 
Table 3 counts of $N$. scintillans for both 2017 and 2018

\begin{tabular}{|l|l|l|l|l|}
\hline Count & $\begin{array}{l}\text { Sub Sample } \\
\text { Factor }\end{array}$ & $\begin{array}{l}\text { Abundance (ind. } \\
\mathrm{m}^{-3} \text { ) }\end{array}$ & Date & Location \\
\hline 288 & 64 & 7200 & $29-06-2017$ & $117-$ Z-Holland \\
\hline 158 & 128 & 7900 & $29-06-2017$ & $147-$ Z-Holland \\
\hline 3362 & 64 & 84300 & $20-06-2017$ & $227-$ N-Holland \\
\hline 1915 & 64 & 48000 & $29-06-2017$ & $327-$ Texel \\
\hline 1490 & 32 & 18600 & $29-06-2017$ & $347-$ Texel \\
\hline 449 & 32 & 5600 & $07-05-2017$ & $427-$ Ameland \\
\hline 1233 & 64 & 30900 & $06-20-2018$ & $557-$ Schiermonnikoog \\
\hline
\end{tabular}

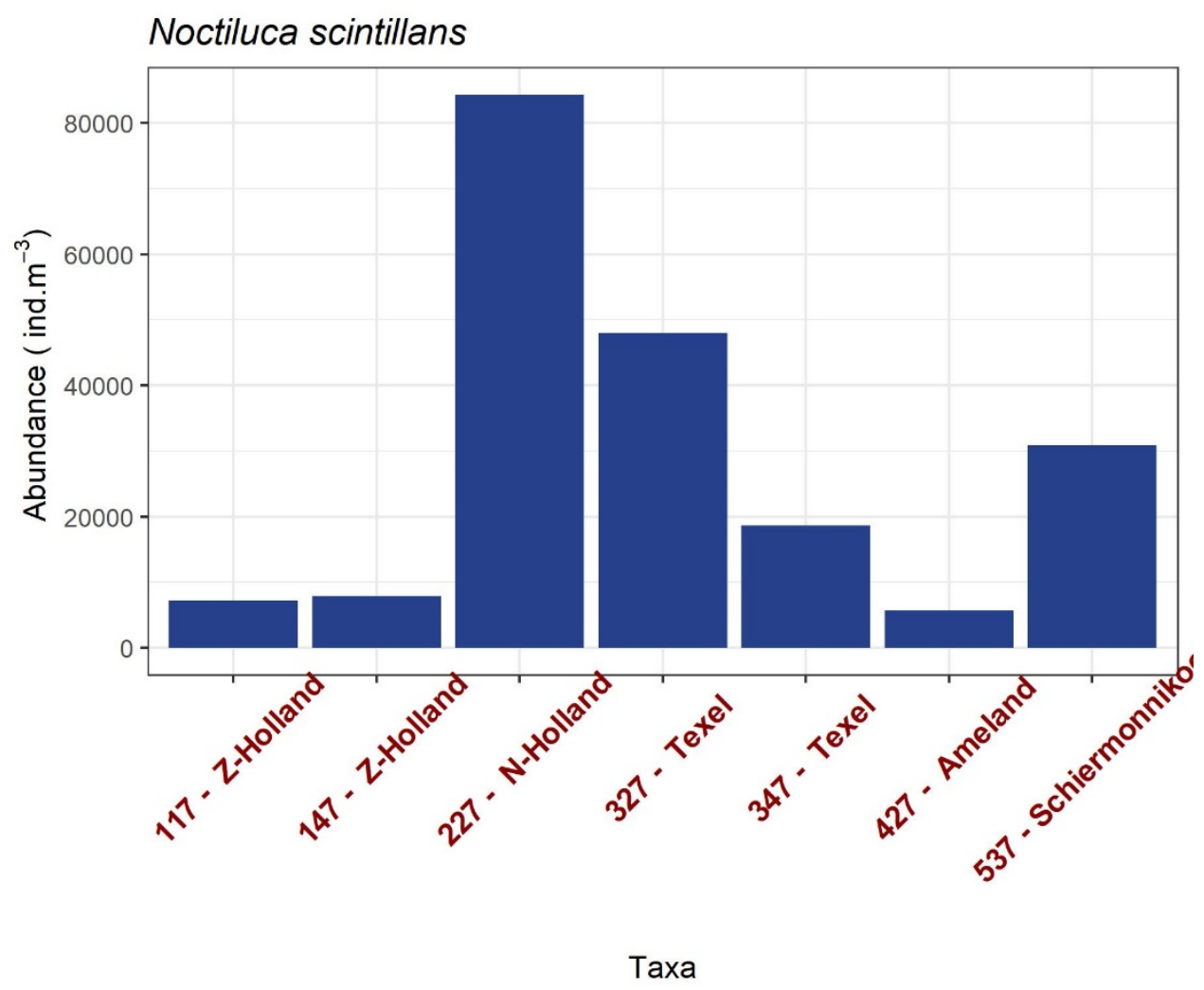

Figure 19. Density of $\boldsymbol{N}$. scintillans at different locations in 2017 . For Z-Holland and Texel two samples have been analysed. 


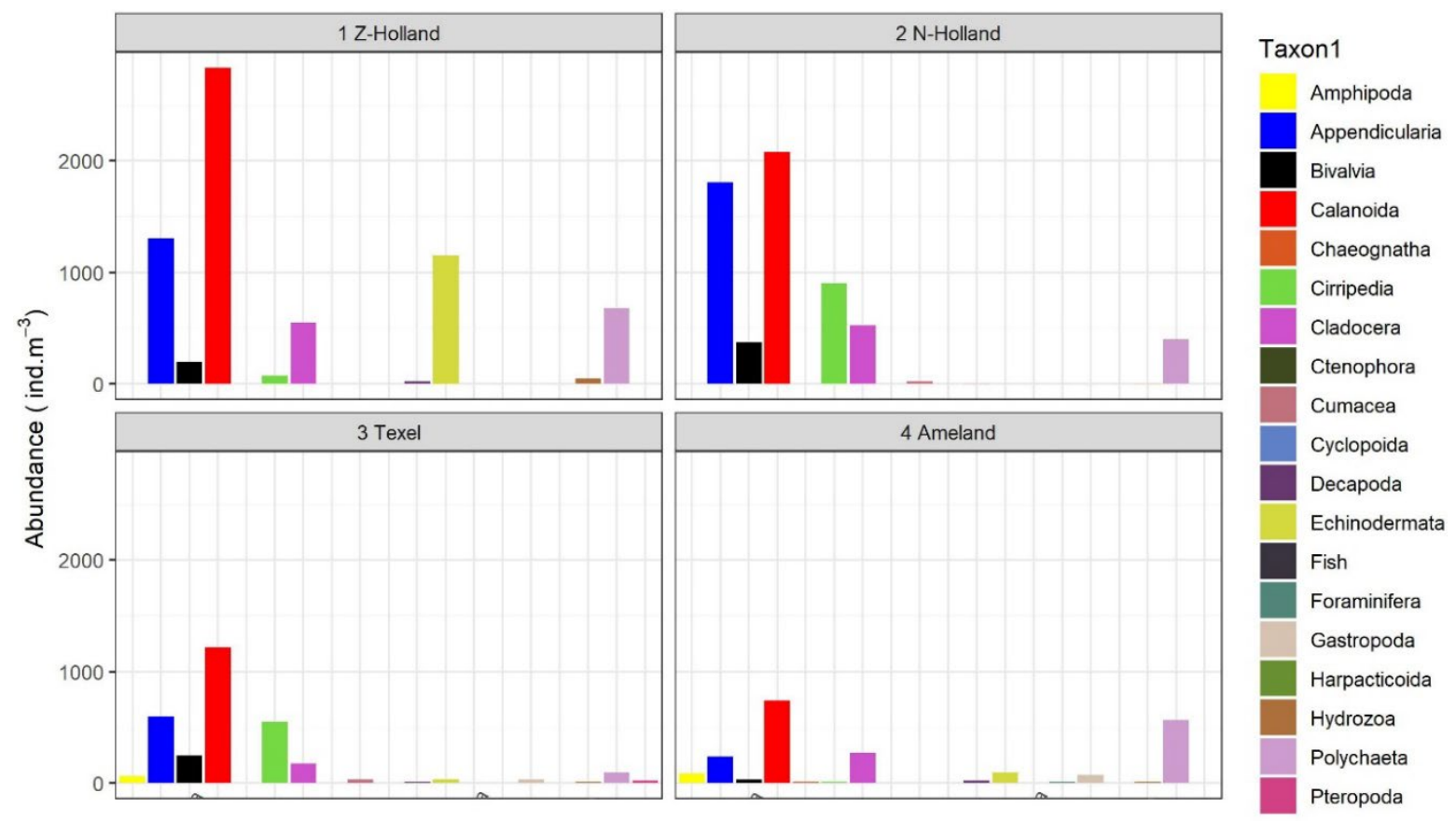

Figure 20. Composition of the zooplankton groups 


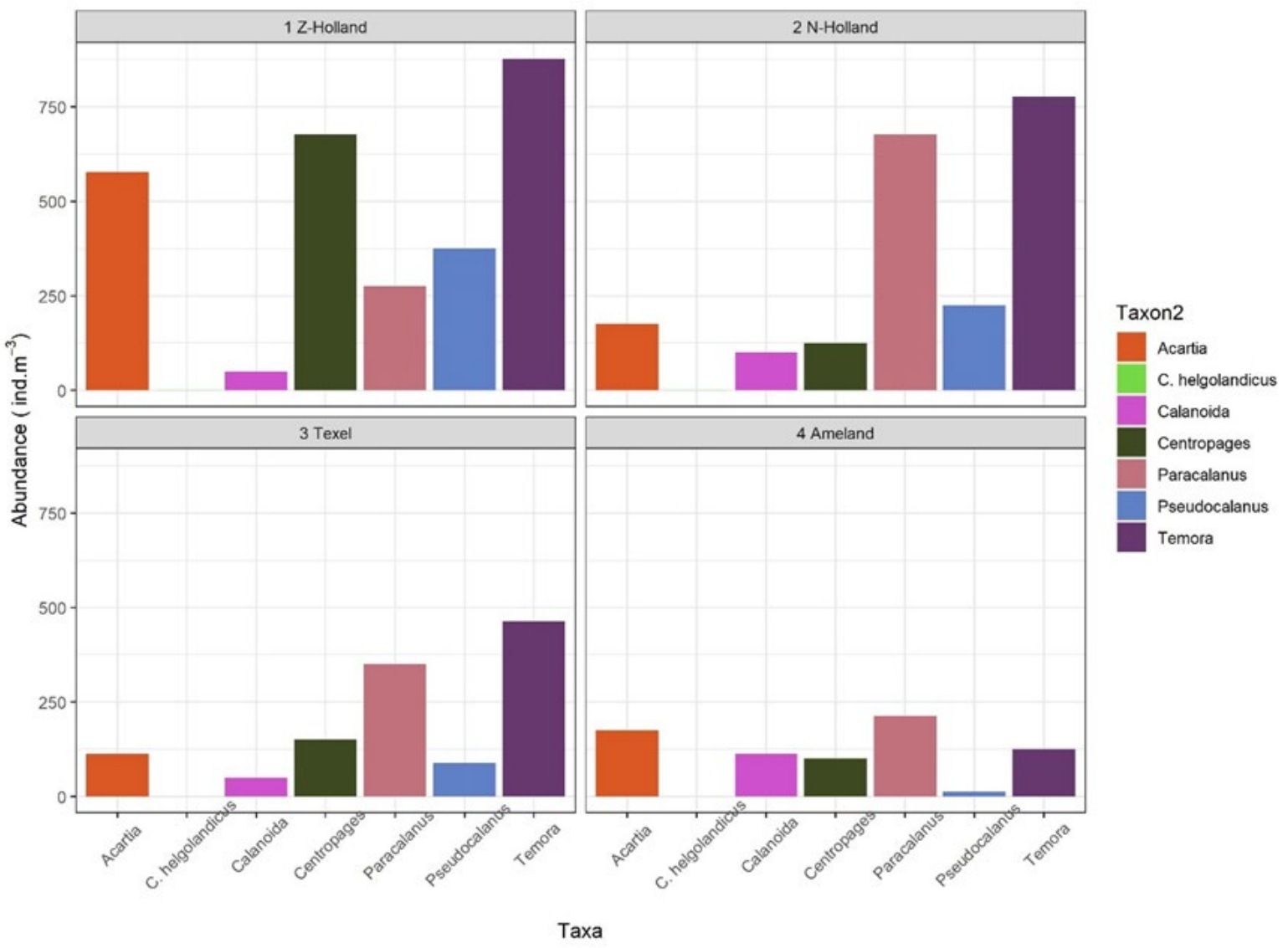

Figure 21. Group Calanoida shown in Figure 19 broken down into genus level.

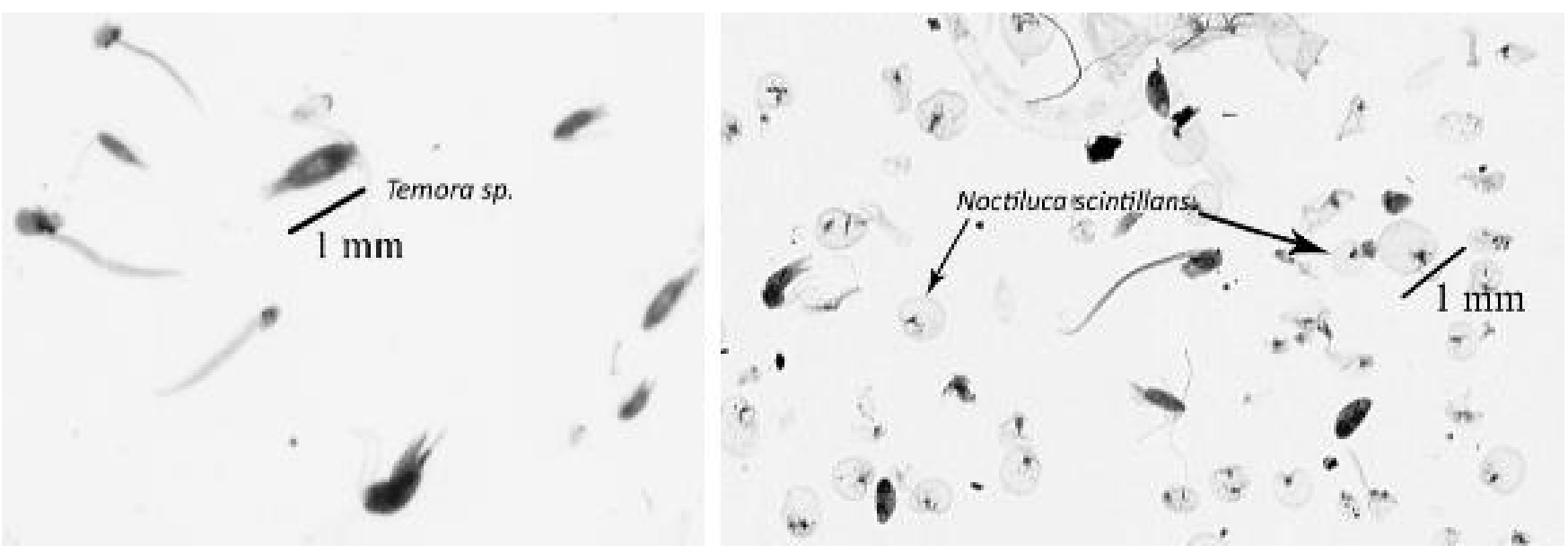

Figure 22. Example of a scan from the processed samples. Left panel shows examples for Temoridae with other species such as Centropagidae and Appendicularia. Right panel shows an example for the most dominant species, $\mathbf{N}$. scintillans. 


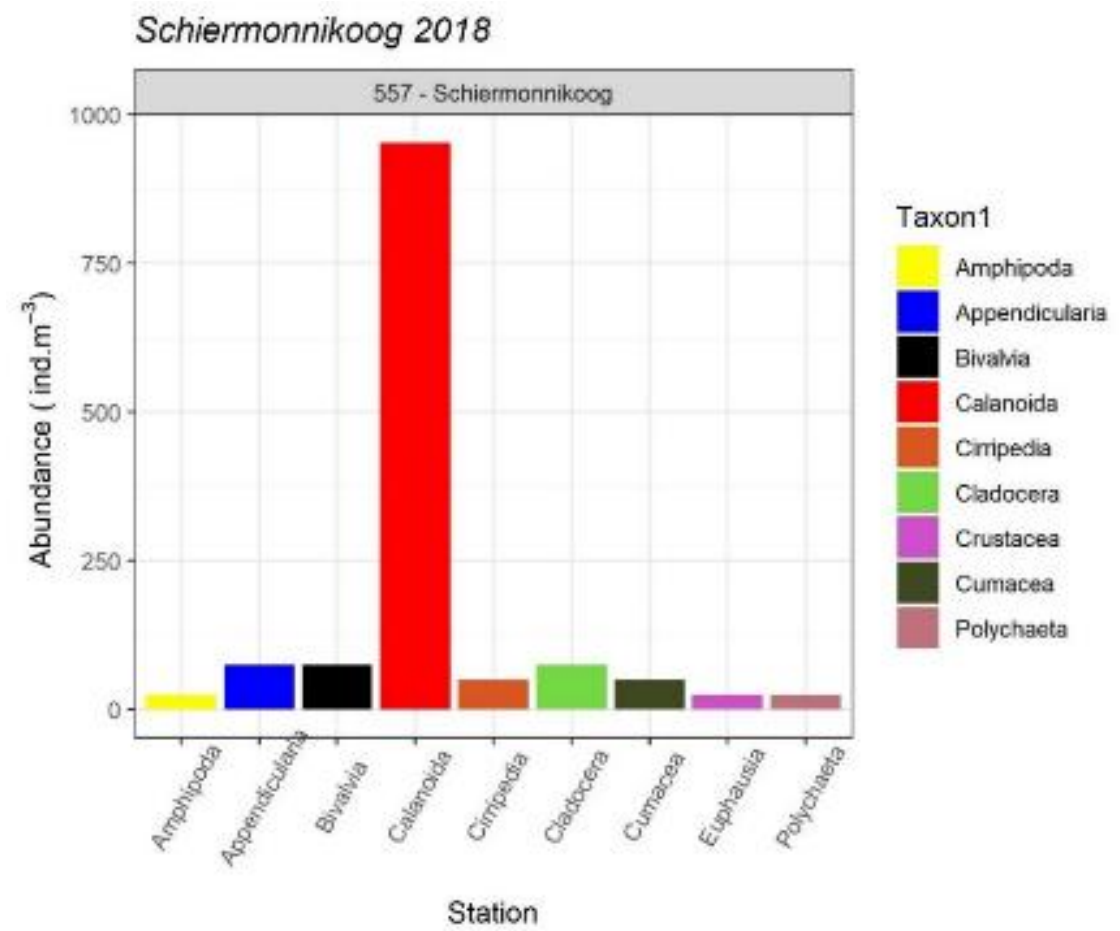

Figure 23. Preliminary counts of a selection of groups of the 2018 sample from Schiermonnikoog. 


\section{$4 \quad$ Discussion and conclusions}

\subsection{Distribution and abundance}

The strong differences between the means and medians of NASC's per survey day give an impression of the patchiness of the distribution. This high degree of patchiness is - in comparison with demersal species - normal for pelagic fish due to fast swimming and schooling behaviour which leads to rapid forming and dissolving of aggregations. This is the reason that trawl surveys are generally not a good method to survey pelagic (schooling) fish.

It is therefore not surprising that the recorded NASC's on small scale sampling units of $100 \mathrm{~m}$ were highly variable. The same is the case for the calculated densities. The best estimates are provided if sailed sections between the beam trawl tracks are included because of the higher number of data points in comparison to trawl tracks only. The overall estimate of $98 \mathrm{~kg} / \mathrm{ha}$ of all survey days together is lower than the value of $184 \mathrm{~kg} / \mathrm{ha}$ and $188 \mathrm{~kg} / \mathrm{ha}$ at low tide found in May 2010 and 2011 in the Marsdiep area (Couperus et al. 2016) but can still be considered in the same order of magnitude. The NASC's found at Schiermonnikoog were much lower. We have no explanation for this and can only speculate that the nutritious "coastal river" along the Dutch coast, which hold high densities of young herring - hatched in the spawning area in in the Channel ("Down's Herring") and sprat, becomes more diluted after it flows into the German Bight.

It was not possible to make a distinction between different species. At the start of this project the intention was to collect samples of the recorded schools with a pelagic trawl. Unfortunately, during the preparations of the survey, the ship owner (Rijksrederij) decided that adaptation of the MS Luctor to make it suitable for pelagic fishing was too expensive. As a suboptimal alternative we used beam trawl catches to compare the acoustics with fish observations.

The presented densities should be treated with much caution and are given here only to give an idea of the order for magnitude in comparison to the numbers given for the Marsdiep area. Despite the fact that $73 \%$ of the beam trawl hauls contained herring or sprat thus indicating that the schools observed might have been clupeids, almost half of the catches (49\%) contained a few specimens of sandeel (see Annex 4). Sandeel has a very different TS-length relationship (Ammodytes marinus: 20LogL93.1; Kubilius and Ona, 2012). Applying a TS-relationship for sandeel instead of mixed clupeids, with the mean length of sandeel in the catches (Van Hal et al., 2017: $11.86 \mathrm{~cm}$ ) and the length weight relationship for $A$. tobianus off the Dutch coast (Grift et al., 2004) the densities would become 70 times higher.

In addition, the TS-length relationship for clupeids that was applied, was derived from echo data in the eastern North Sea with different environmental conditions (less suspended silt, deeper) compared to the Dutch coast. There is a need to assess available acoustic $200 \mathrm{kHz}$ data in the Dutch coastal zone for the possibility to derive more precise TS values. The acoustic response in shallow water may be different for $200 \mathrm{kHz}$ transducer (Fässler et al. 2007; Scoulding et al. 2017).

Herring was the most dominant species in the beam trawl catches in numbers, but the distribution was skewed: the high catches originated mainly from Zuid-Holland. The probability that the observed schools in the Zuid-Holland location are correctly assigned to herring (or clupeids) is therefore larger than at the other locations. Hence the calculated density for Zuid-Holland is more reliable than for Noord-Holland and Texel.

Despite the uncertainties mentioned above this study confirms the findings of Couperus et al. (2016) that densities of pelagic fish in the coastal zone are an order of magnitude higher than densities of demersal fish species within the same area and play an important role in the coastal ecosystem. 


\subsection{Acoustics and beam trawl}

This study provides an opportunity to compare beam trawl catches directly with acoustic data. When estimating abundance of pelagic fish in open sea and oceans it is considered common knowledge that trawling does not give robust estimates of schooling fish. That is the reason to carry out acoustic surveys in the first place. Why would one want to test whether there is a relationship between acoustic recordings and the trawl catches? The reason we have done this is because all routine trawl surveys in the Dutch coastal zone are carried out with a beam trawl. There is no survey along the Dutch coast dedicated to pelagic fish. Hence beam trawl data is all we have. In previous studies (e.g. Couperus et al, 2016) it was found that in turbid conditions, the distribution of small pelagic fish is more scattered: fish was distributed in many small schools rather than in a few big schools, which would mean that some kind of trawl survey may be more effective compared to normal open sea conditions. In the third place we considered that the catchability of trawls increases in turbid conditions. An additional incentive to test this, is that we were put in a situation with acoustic equipment, without a pelagic trawl.

The comparison between fish catches and acoustic recordings is not straightforward, because for a precise interpretation of the acoustic recordings knowledge of the species composition and the length distribution is required and this information comes from trawl catches. On the other hand, if beam trawl catches are a measure for the abundance of pelagic fish, one would expect a relationship between the strength of the acoustic recordings during the haul and the number of pelagic fish in the catch. Figure 10 clearly shows that there is no relationship between the two. The likely reason is that the trawl catches simply miss the schools and pick up some stray fish that are not connected to a school. Occasional the beam trawl may "hit" a small school, which results in thousands of fish in that particular catch. This is an explanation for the high catches of small pelagic fish in the Zuid-Holland area. The chance to hit a school - the catchability - on that survey day and/or in that area was for unknown reasons apparently higher than on other survey days.

This means that an $3 \mathrm{~m}$ beam trawl survey cannot be used as an index for small pelagic fish in the Dutch near coastal zone. Individuals of fish in the catch can still be used for information on whether a species lives in the area and it gives lengths and weights which can be used for the calculation of fish abundance. One can question the representativeness of this individuals as they may be weaker, smaller than fishes in the schools that managed to escape from the net. This is an issue in all fisheries studies in which bottom trawls are being used and does not withheld scientists from using these data anyway as there are no better data available and usually there no indications that catches are not representative because demersal fish is not visible on an echsounder. In surveys targeting pelagic fish this is different as the echosounder provides proof whether there are fish schools under the vessel. In an acoustic survey trawl station are not planned on a grid. The trawl is used to target specific schools that are observed on the echogram to identify the species and collect biological information (Simmonds and MacLennan, 2005).

This leaves the question whether any another, more effective - trawl (or another fishing gear) would be suitable for abundance estimation. Figure 10 and annex 3 show that in most $3 \mathrm{~m}$ beam trawl catches there are at least some pelagic fish. The distribution of NASC's in figure 10 and 17 shows that despite the huge differences in fish densities there is pelagic fish in most of the surveyed coastal areas. In comparison to the open sea pelagic fish is equally spread over the coastal areas. If a proper pelagic trawl is used that catch the schools that are around, this might result in an index for the abundance of pelagic fish. One would have to carry out a power analysis based on the collected data in this study to find out how many trawl stations would have to be planned.

The comparison with the acoustic data shows that there is no relation between the number of pelagic fish in beam trawl catches and the Nautical Area Backscattering Coefficients. On the contrary, the data indicate that the highest acoustic values, coincided with zero catches. To make a distinction between fish species, future acoustic surveys should make use of a (half)pelagic gear to be able to identify the acoustically recorded species. 
The variability in densities is may be enhanced by the narrow survey area. Pelagic fish can be expected to swim rapidly in and out of the narrow operation zone of $3-12 \mathrm{~m}$. This may be related to tide (Couperus et al. 2016). The GAM analysis on depth, time of the day and tidal state, showed that the data in this study was over dispersed and none of the explanatory variables explained the variability. One potential reason for this may be that the survey coverage is not extensive enough to capture the spatial-temporal variability for the distribution of the population of small pelagic fish in the study area.

\subsection{Avoidance?}

The set up with a transducer at the bow and a transducer in a towed body that that sheared away from the vessel provided a unique opportunity to study possible avoidance behaviour. Escape and avoidance behaviour is a general concern in acoustic surveys. In the North Sea at depths of approximately $100 \mathrm{~m}$, there is evidence that the acoustic index is not biased by escape behaviour adult herring (Fernandes et al, 2000a, 2000b). Close to the coast in shallow waters this may be different.

There was no significant difference between the acoustic recordings at the bow and under the towed body out of the course line. This indicates that during acoustic surveying the recorded data are not biased by avoidance, although it is still possible that fish avoids both the vessel and the towed body. Another possibility is that part of the fish is chased away from the bow and is recorded under the towed body, but this seems less likely as the NASC's from the towed body was lower than the NASC's from the bow (although not significantly). Another source of bias is the orientation of the fish towards the transducers affects the TS-length relationship of the fish involved. This would lead to a bias in the calculation of the fish densities.

There is also (avoidance) behaviour of fish that has no consequences for the estimation of pelagic fish distribution: fish swimming forward in front of the bow would be detected anyway. Likewise, fish swimming towards the vessel will be detected. As the swimming speed of young pelagic fish is much lower than the ships speed it is not likely that this will lead to an over estimation - fish swimming in the ships direction - or under estimation - ship swimming in the opposite direction. Nevertheless, the expected response (downwards and perpendicular to the ships direction) may not be equally strong under all conditions. Sea state, transparency, current and external factors (e.g. other ships, predators like birds and fish) may have impact on the behaviour. However, the data contain many zeroes and the values are highly variable: the number of data points is too low for a more extensive analysis with these additional variables.

\subsection{Impact of sand nourishments}

Given the estimated densities of pelagic fish off the Dutch coast, pelagic fish plays an important role in the local ecosystem. Knowledge on the juveniles in the Dutch coastal waters is limited due to the lack of attention towards pelagic fish. As a result, insight in the role of small pelagics is poor, making the development of specific research questions on the impact of sand nourishments and on how to design nourishments to benefit pelagic fish difficult or impossible. The current investigations add to gain more knowledge.

The sand nourishments might change the sediment particle size and permeability of the sediment. This might affect the burying possibilities of the semi-pelagic sandeel species (Ammodytes tobianus and $A$. marinus). These species bury themselves in the sand at night and in winter. Sandeel prefers the coarse sands with particle sizes of 250-1000 $\mu \mathrm{m}$ with low silt content (0-63 $\mu \mathrm{m}$ ) (Reay 1970; Wright et al. 2000 and for the Dutch coast by Tien et al., 2017). Our data (Annex 3) indicated a similar preference with more sandeel found add courser sediments. Thus, nourishments with other particles sizes than available prior to the nourishment might alter the distribution of sandeel. Nourishments with the same particle size, possibly increasing permeability might enhance the 
presence of sandeel as observed shortly after the nourishment in the Amelander Zeegat area (van Hal and Volwater, 2019). With average sediment particle sizes of around $240 \mu \mathrm{m}$ most of that area is softer than preferred by sandeel. Adding courser materials might increase the area with preferred conditions by sandeel. Our results show no relation between the NASC and the average particle size, which is as expected as the NASC is combination of sandeel and the full pelagic species not related to the sediments. This study did not address the relation with sediment further as the focus was on fish in water column. To test the impact of sand nourishments on the distribution of sandeel species, future studies should include night time bottom sampling.

The other hypothesized impact of nourishments might be that pelagic fish (distribution) may temporarily be affected because of increased turbidity. Schools of pelagic fish are smaller in conditions with less visibility (Ryer and Olla, 1998a,b) and are more scattered distributed (Vabo et al., 2002). We found no relation between the NASC and the Secchi-observation of water visibility (Annex 3 ). This might be because the NASC is a combination of species, where individual species might respond differently to water visibility. The study shows that the acoustic set up used, seems useful to test changes in pelagic species distribution during and shortly after sand nourishment activities, however future validation is needed to make it suitable for scientific and operational data approval.

\subsection{Zooplankton}

The zooplankton samples were dominated by $N$. scintillans. It is a non-photosynthetic omnivorous dinoflagellate species commonly found throughout the world in the neritic (coastal) temperate environments generally forming extensive red tides (when they reach to the height of their bloom (Fock and Greve, 2002) and therefore categorized as an element of harmful algal blooms. Although this opportunistic species does not produce toxins, its excessive densities may potentially cause oxygen depletion and elevation of ammonium concentrations (Al Gheilani et al., 2011; Do Rosário Gomes et al., 2014).

Furthermore, as they dominate the environment, they may outcompete the species in the local assemblage and alter the food web dynamics. They are voracious predators collecting the prey items with their tentacles with random movements and their diet range from microbes to phytoplankton and even to small copepods, their nauplii and eggs (Kiprboe and Titelman, 1998; Quevedo et al., 1999). Despite these potential perturbative factors, there is no evidence in the literature linking them to a severe impact to the fish communities in the neritic environment of the southern North Sea. Therefore, the high abundance of the $N$. scintillans found in this study may potentially be considered as a temporary phenomenon in the study area at this time of the year.

In all stations in 2017, Genus Temora, Centropages and Acartia are the main species potentially comprising the main prey for the small pelagic fish. In a relatively recent study in the Belgian part of the North Sea Van Ginderdeuren et al. (2014a) looked at the diets of the most common pelagic fish species such as sprat, juvenile herring and adult herring. They found that the calanoid copepods, and particularly the Temora longicornis and to a lesser extent Centropages hamatus dominated the stomach of both herring and sprat where the two of these species accounts for nearly three-quarters of the prey.

In another study in the same area Van Ginderdeuren et al. (2014b) investigated mesozooplankton assemblage through monthly samples with a WP2 net in 2009 and 2010 at 10 different species again in the Belgium coast of the North Sea. They showed also that, after N. scintillans, the most dominant taxa were copepods (Temora longicornis, Acarcia clausi, Paracalanus parvus, Centropages hamatus, Pseudocalanus elongatus, Centropages typicus, Calanus helgolandicus and the harpacticoid Euterpina acutifrons). The findings in our study are consistent with Van Ginderdeuren et al. (2014b) at genus level (in the present study we did not identify to species level). Total abundance of copepods changing between 1000-3000 individuals per m-3 between the stations is also in line with the findings of Van Ginderdeuren.

The most dominant copepod species both Temora and Centropages are small copepods not larger than $1 \mathrm{~mm}$ prosome lengths and primarily graze on phytoplankton responsible for transferring the energy from primary producers to fish (Tiselius, 1989; Franco-Santos et al., 2018). 
Despite the importance of the zooplankton as food for the juvenile pelagic species, we did not find a link between higher abundances of zooplankton and those of the pelagic fish species. In future studies copepods should be identified to species level to be able to link changes in distribution and abundance of pelagic fish. Copepods species have different life cycles, and which may the key to the timing of zooplankton availability for predators like sandeel and clupeids.

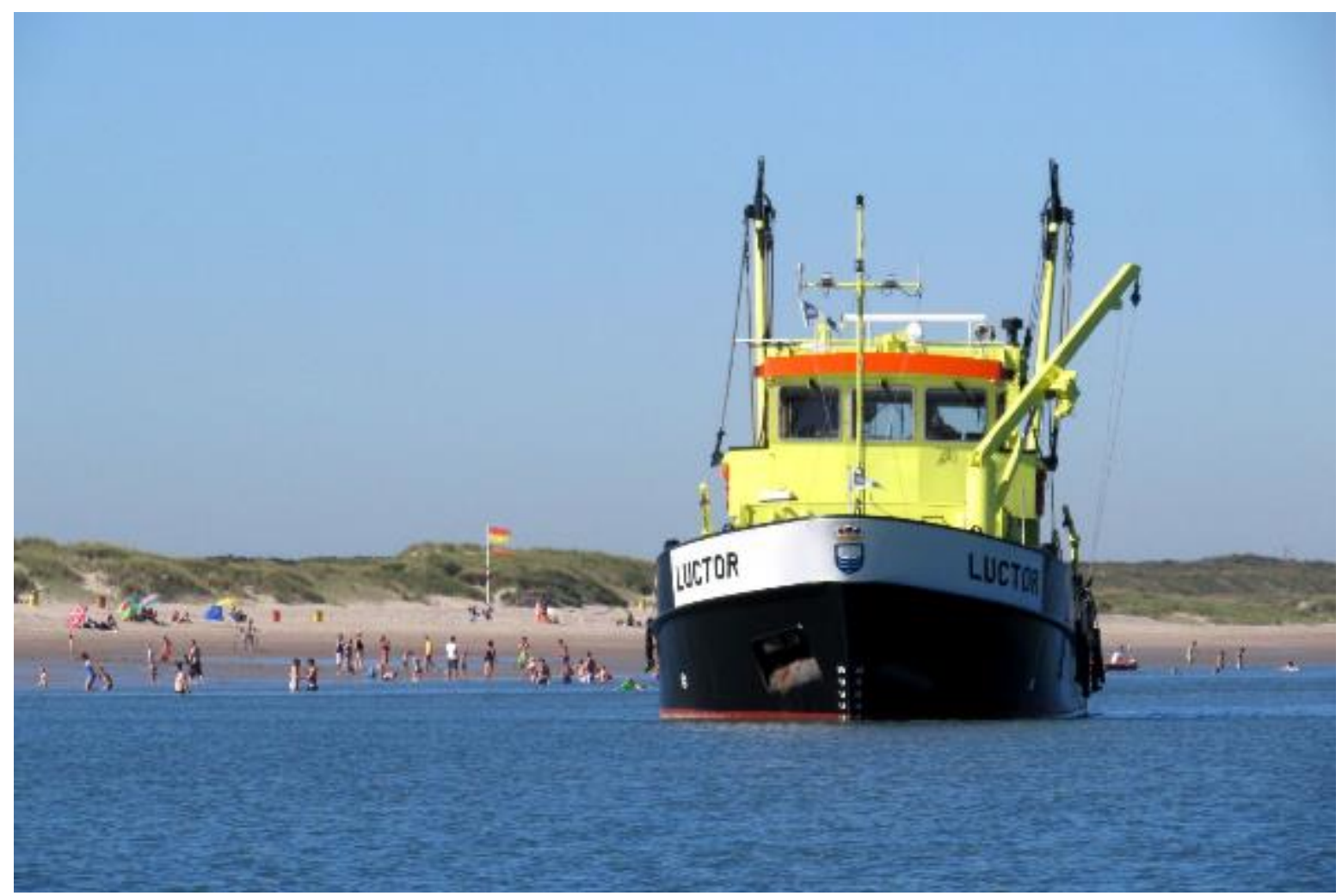

Figure 24. The research vessel MS Luctor of the coast of Zoutelande in 2016 during the experimental survey in 2016. 


\section{Conclusions}

High degree of patchiness as is to be expected in pelagic fish, but the fish is not concentrated in a few "hotspots": it is still spread along the coast.

The NASC's found at Schiermonnikoog were much lower.

The presented densities of clupeids are in the same order of magnitude as found in an earlier study in the Marsdiep area under the assumption that all acoustic backscatter can be attributed to clupeids. As it was not possible to collect reliable catches (see below), it is possible that part of the NASC's come from sandeel, a species a species with a much lower acoustic Target Strength. This would mean that the densities of clupeids would be a little lower, but it would increase the biomass of sandeel to a large extend.

The use of a $3 \mathrm{~m}$ beam trawl in the Dutch coastal is proven to be very unreliable. There is no relation between the recorded fish schools and $3 \mathrm{~m}$ beam trawl catches. Catches can only be used in the sense that if a species occurs in the catch it was apparently in the area.

The acoustic backscatter attributed to pelagic fish is not biased by tidal state or time of the day (at day light).

There is no indication that the acoustic index is biased by fish avoiding the vessel. Therefore, in future acoustic survey in the near coastal zone, the deployment of the transducer(s) near the bow is a reasonable option.

The present study does not add to possible impact of sand nourishment on the abundance and distribution of pelagic fish. Potentially sand nourishment may have an impact on sandeel (Ammodytes spp.), which live part of its life in the sand and depends on sediments of specific particle sizes. Sandeel species spend part of their life in the pelagic. To test the impact of sand nourishments on the distribution of sandeel species, future studies should include in bottom sampling at night time. This study shows that the acoustic set up is suitable to carry out experiments to test changes in pelagic species distribution during and shortly after sand nourishment activities if proper fishing gear is available.

The zooplankton samples were dominated by N. scintillans. Apart from this species, copepods of the genuses Temora, Centropages and Acartia are the main species potentially comprising the main prey for the small pelagic fish. 


\section{Advice for future work}

To make a distinction between fish species, future acoustic surveys should make use of (half)pelagic gear to be able to identify the acoustically recorded species.

In future acoustic survey in the near coastal zone, the deployment of the transducer(s) near the bow is a reasonable option.

In future studies at daylight in surveys in the near coastal zone with the objective to study effect of time of the day and tidal state, the scale of the survey should be extended towards a larger distance from the coast, for example more than 10 nautical miles.

In zooplankton sampling it is recommended to identify copepods to species level. Copepods species have different life cycles, which maybe the key to the timing of zooplankton availability for predators like sandeel and clupeids. 


\section{References}

Al Gheilani, H. M., Matsuoka, K., AlKindi, A. Y., Amer, S., and Waring, C. 2011. Fish Kill Incidents and Harmful Algal Blooms in Omani Waters. Journal of Agricultural and Marine Sciences [JAMS].

Baptist, M., L. Bolle, B. Couperus, I. Tulp, and R. Van Hal. 2017. Ecologisch Gericht Suppleren; Meetplan geïntegreerde ecosysteem survey 2017. Wageningen University and Research. Report C017/17: 40pp.

Couperus, B., S. Gastauer, S. M. M. Fässler, I. Tulp, H. W. van der Veer, and J. J. Poos. 2016. Abundance and tidal behaviour of pelagic fish in the gateway to the Wadden Sea. Journal of Sea Research 109: 42-51.

Dänhardt, A., and P. Becker. 2011a. Does small-scale vertical distribution of juvenile schooling fish affect prey availability to surface-feeding seabirds in the Wadden Sea? Journal of Sea Research 65: 247255

Dänhardt, A., Becker, P.H., 2011b. Herring and sprat abundance indices predict chick growth and reproductive performance of common terns breeding in the Wadden Sea. Ecosystems 14 , 791-803.

Dänhardt, A., Fresemann, T., Becker, P.H., 2011. To eat or to feed? Prey utilization of Common Terns Sterna hirundo in the Wadden Sea. J. Ornithol. 152, 347-357.

Do Rosário Gomes, H., Goes, J. I., Matondkar, S. G. P., Buskey, E. J., Basu, S., Parab, S., and Thoppil, P. 2014. Massive outbreaks of Noctiluca scintillans blooms in the Arabian Sea due to spread of hypoxia. Nature Communications.

Dickey-Collas, M., L. J. Bolle, J. K. L. van Beek, and P. Erftemeijer. 2009. Variability in transport of fish eggs and larvae. II. Effects of hydrodynamics on the transport of Downs herring larvae. Marine Ecology Progress Series 390: 183-194.

Fässler, S. M. M., R. Santos, N. García-Núñez, and P. G. Fernandes. 2007. Multifrequency backscattering properties of Atlantic herring (Clupea harengus) and Norway pout (Trisopterus esmarkii). Canadian Journal of Fisheries and Aquatic Sciences 64: 362-374.

Fock, H. O., and Greve, W. 2002. Analysis and interpretation of recurrent spatio-temporal patterns in zooplankton dynamics: A case study on Noctiluca scintillans (Dinophyceae) in the German Bight (North Sea). Marine Biology.

Franco-Santos, R. M., Auel, H., Boersma, M., De Troch, M., Meunier, C. L., and Niehoff, B. 2018. Bioenergetics of the copepod Temora longicornis under different nutrient regimes. Journal of Plankton Research.

Grift, R. E., A. S. Couperus, M. S. Ybema, and N. S. H. Tien. 2004. Base line studies North Sea wind farms: biological data pelagic fish. IJmuiden: RIVO - Netherlands Institute for Fisheries Research, report: 48pp.ICES. 2014. Report of theWorking Group of International Pelagic Surveys (WGIPS). ICES CM 2014/SSGESST:01: 360.

Jennings, G., D. J. McGlashan, and R. Furness. 2012. Responses to changes in sprat abundance of common tern breeding numbers at 12 colonies in the Firth of Forth, east Scotland. ICES Journal of Marine Science 69: 572-577.

Kiprboe, T., and Titelman, J. 1998. Feeding, prey selection and prey encounter mechanisms in the heterotrophic dinoflagellate Noctiluca scintillans . Journal of Plankton Research.

Kubilius, R., and Ona, E. 2012. Target strength and tilt-angle distribution of lesser sandeel (Ammodytes marinus) - ICES Journal of MarineScience, 69: 1099-1107.

Mulder, J.P.M., Hommes, S. and Horstman, E.M. (2011) Implementation of coastal erosion management in the Netherlands. Ocean \& coastal management 54: 888-897.

Quevedo, M., Gonzalez-Quiros, R., and Anadon, R. 1999. Evidence of heavy predation by Noctiluca scintillans on Acartia clausi (Copepoda) eggs off the central Cantabrian coast (NW Spain). Oceanologica Acta.

Reay, 1970. Synopsis of Biological Data on North Atlantic Sandeels of the Genus Ammodytes. FAO Fisheries Synopsis No. 82.

Ryer, C.H., Olla, B.L., 1998a. Effect of light on juvenile walleye pollock shoaling and their interaction with predators. Mar. Ecol. Prog. Ser. 167, 215-226.

Ryer, C.H., Olla, B.L., 1998b. Shifting the balance between foraging and predator avoidance: the importance of food distribution for a schooling pelagic forager. Environ. Biol. Fish 52, 467-475.

Scoulding, B., S. Gastauer, D. N. MacLennan, S. M. M. Fässler, P. Copland, P. G. Fernandes, and D. Handling editor: David. 2017. Effects of variable mean target strength on estimates of abundance: the case of Atlantic mackerel (Scomber scombrus). ICES Journal of Marine Science 74: 822-831. 
Simmonds, J., and D. MacLennan. 2005. Fisheries Acoustics - Theory and Practice. Oxford BlackwellScience Ltd.: 456pp.

Fernandes, P.G., Brierley, A.S., Simmonds, E.J., Millard, N.W., McPhail, S. D., Armstrong, F., Stevenson P. and Squires, M. 2000a. Fish do not avoid survey vessels. Nature 407: 152.

Fernandes, P.G., Brierley, A.S., Simmonds, E.J., Millard, N.W., McPhail, S. D., Armstrong, F., Stevenson P. and Squires, M. 2000b. Fish do not avoid survey vessels - Addendum. Nature 404: 35- 36.

Stienen, E. W. M. 2006. Living with gulls. Trading off food and predation in the Sandwich Tern Sterna sandvicensis (PhD thesis), University of Groningen, Groningen.

Tien, N. S. H., J. Craeymeersch, C. van Damme, A. S. Couperus, J. Adema en I. Tulp (2017) Burrow distribution of three sandeel species relates to beam trawl fishing, sediment composition and water velocity, in Dutch coastal waters. Journal of Sea Research 127: 194-202.

Tiselius, P. 1989. Contribution of aloricate ciliates to the diet of Acartia clausi and Centropages hamatus in coastal waters. Marine Ecology Progress Series.

Vabo, R., Olsen, K., Huse, I., 2002. The effect of vessel avoidance of wintering Norwegian spring spawning herring. Fish. Res. 58, 59-77.

Van Ginderdeuren, K., Vandendriessche, S., Prössler, Y., Matola, H., Vincx, M., and Hostens, K. $2014 a$. Selective feeding by pelagic fish in the Belgian part of the North Sea. ICES Journal of Marine Science.

Van Ginderdeuren, K., Van Hoey, G., Vincx, M., and Hostens, K. 2014b. The mesozooplankton community of the Belgian shelf (North Sea). Journal of Sea Research.

Van Hal, R., B. Couperus, A. Dijkman-Dulkes, and M. Baptist. Reisverslag kustsurvey EGSII; Juni-juli 2017. Wageningen University and Research. Report C075/17: 25pp.

Van Hal, R., and Volwater, J. 2019. Zandspiering in het Amelander Zeegat T1-meting voorjaar 2019. Wageningen Marine Research, rapport C105/19.

Wright, P.J., Jensen, H., Tuck, I., 2000. The influence of sediment type on the distribution of the lesser sandeel, Ammodytes marinus. J. Sea Res. 44, 243-256.

Zijlstra, J. J. 1972. Report on the International Surveys of Herring Larvae in the North Sea and Adjacent Waters in 1970/71. ICES Coop. Res. Rep. Ser. A 28: 1-24. 


\section{Quality Assurance}

Wageningen Marine Research utilises an ISO 9001:2008 certified quality management system (certificate number: 187378-2015-AQ-NLD-RvA). This certificate is valid until 15 September 2018. The organisation has been certified since 27 February 2001. The certification was issued by DNV Certification B.V.

Furthermore, the chemical laboratory at IJmuiden has NEN-EN-ISO/IEC 17025:2005 accreditation for test laboratories with number L097. This accreditation is valid until $1^{\text {th }}$ of April 2021 and was first issued on 27 March 1997. Accreditation was granted by the Council for Accreditation. The chemical laboratory at IJmuiden has thus demonstrated its ability to provide valid results according a technically competent manner and to work according to the ISO 17025 standard. The scope (L097) of de accredited analytical methods can be found at the website of the Council for Accreditation (www.rva.nl).

On the basis of this accreditation, the quality characteristic $Q$ is awarded to the results of those components which are incorporated in the scope, provided they comply with all quality requirements. The quality characteristic $\mathrm{Q}$ is stated in the tables with the results. If, the quality characteristic $\mathrm{Q}$ is not mentioned, the reason why is explained.

The quality of the test methods is ensured in various ways. The accuracy of the analysis is regularly assessed by participation in inter-laboratory performance studies including those organized by QUASIMEME. If no inter-laboratory study is available, a second-level control is performed. In addition, a first-level control is performed for each series of measurements.

In addition to the line controls the following general quality controls are carried out:

- Blank research.

- Recovery.

- Internal standard

- Injection standard.

- Sensitivity.

The above controls are described in Wageningen Marine Research working instruction ISW 2.10.2.105. If desired, information regarding the performance characteristics of the analytical methods is available at the chemical laboratory at IJmuiden.

If the quality cannot be guaranteed, appropriate measures are taken. 


\section{Justification}

Report C060/20

Project Number: 4312100053

The scientific quality of this report has been peer reviewed by a colleague scientist and a member of the Management Team of Wageningen Marine Research

Approved: $\quad$ Ingrid Tulp

Senior researcher

Signature: Jigred 8 wh

Date: 2 July 2020

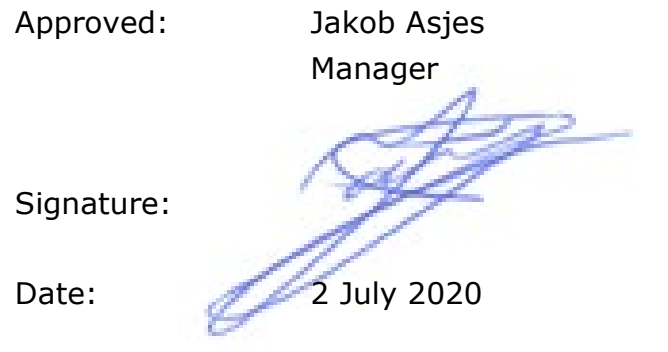




\section{Annex 1 - Sample locations}

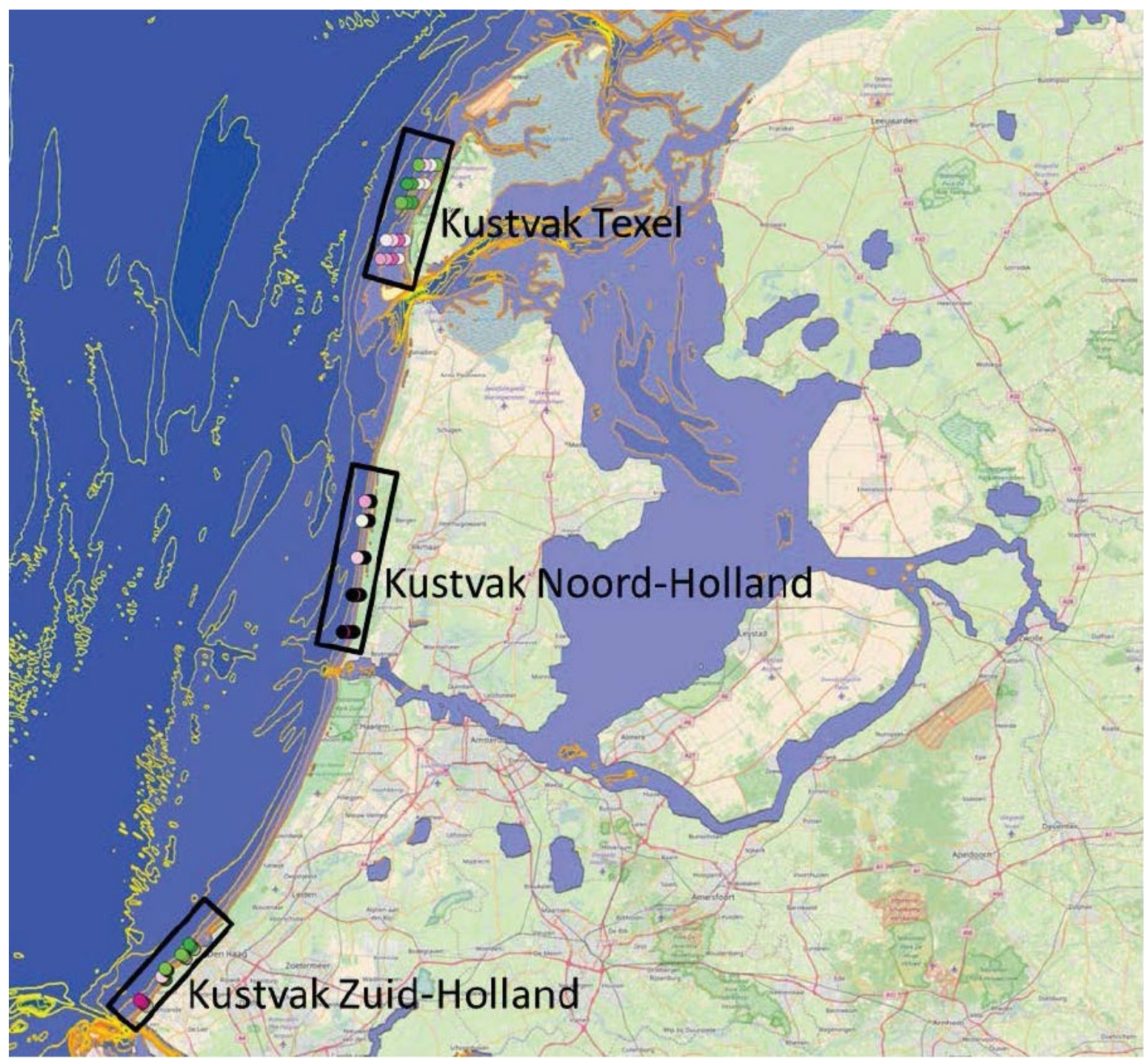

Sample locations with the colour scale representing the median grain size at each sampling location in 2017. 


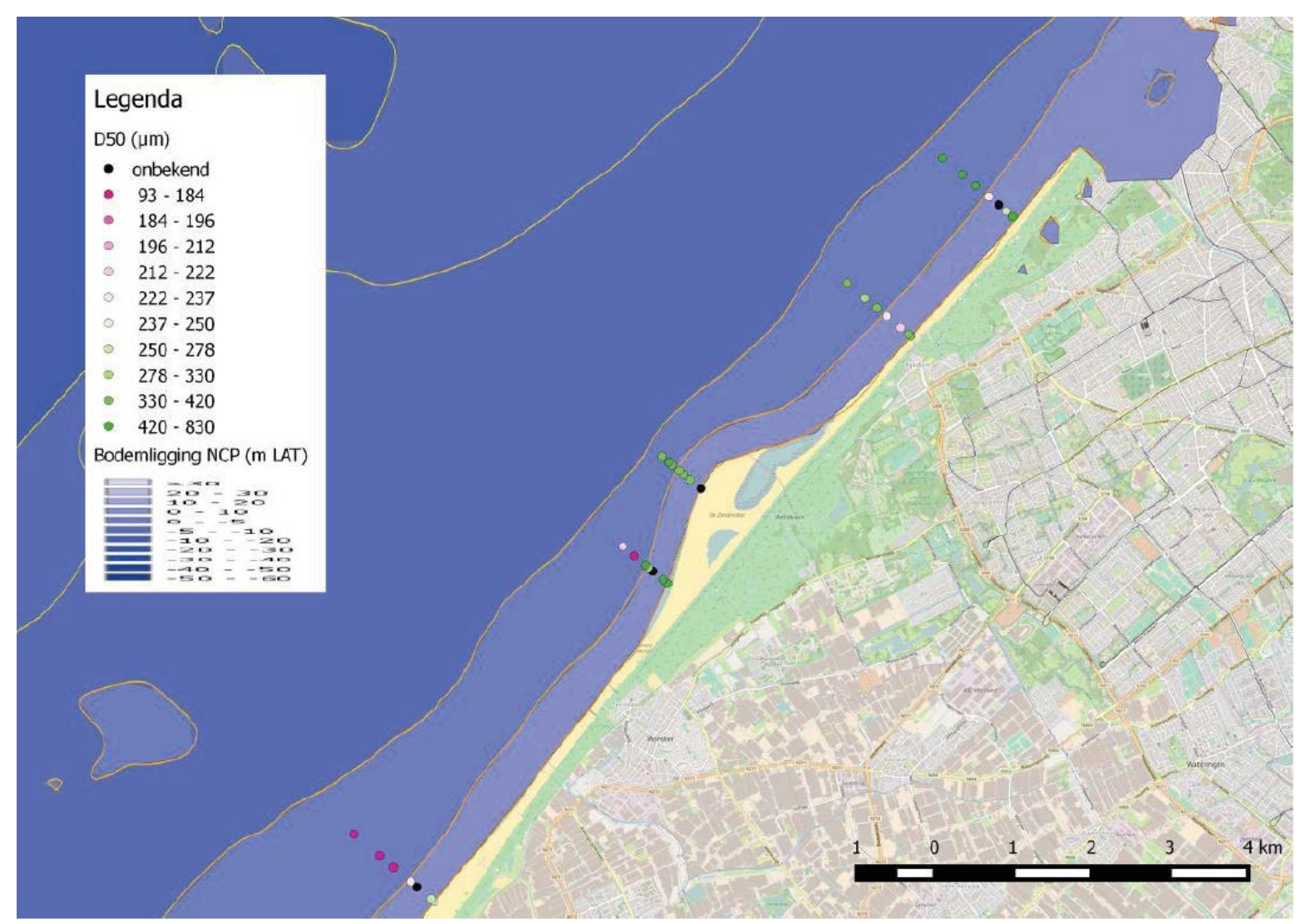

Sample transects with the colour scale representing the median grain size at the location of ZuidHolland in 2017.

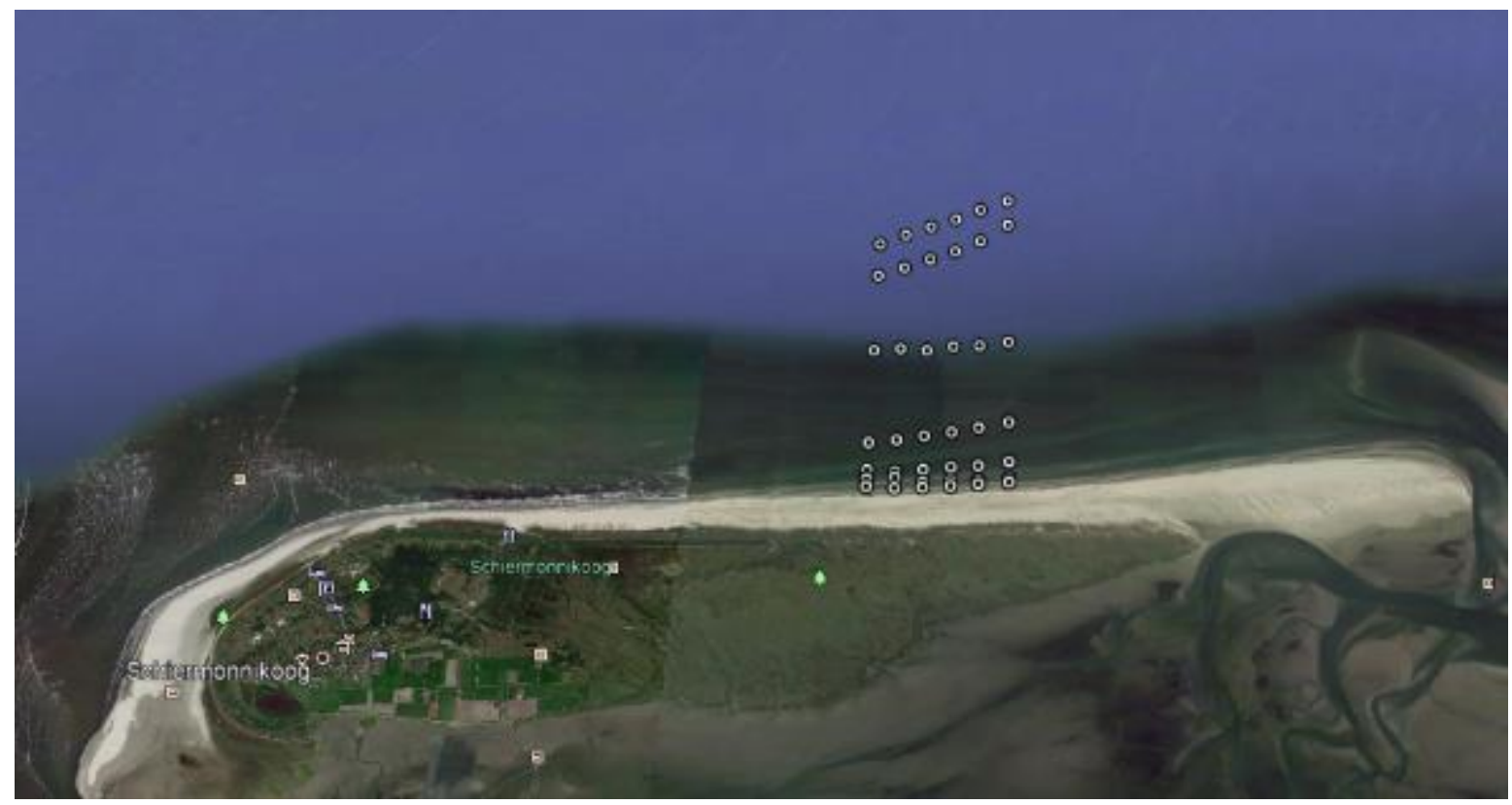

Location of Schiermonnikoog with the 6 transects planned in 2018. 


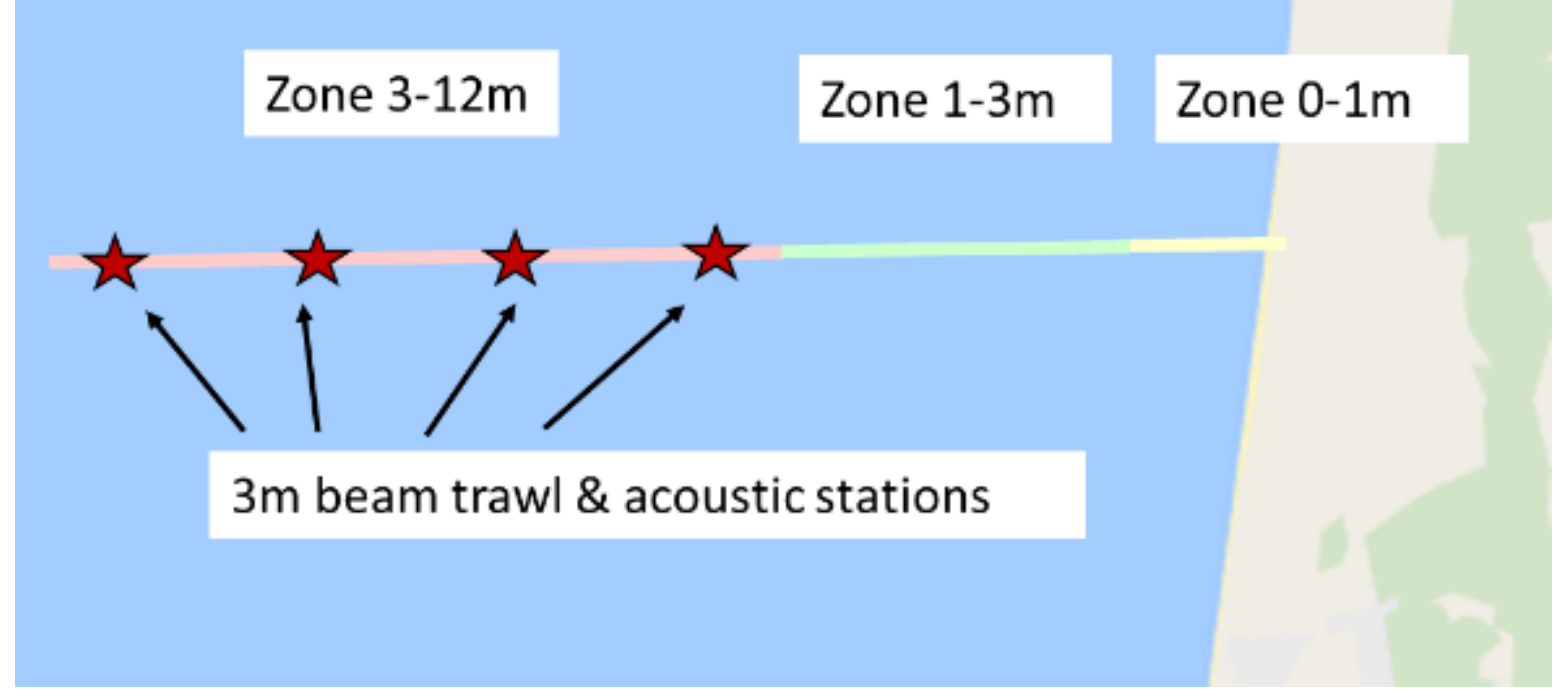

Graphical presentation of a transect. This report does not deal with the shallow zones. 


\section{Annex 2 - Calculation of TS length relationship of small clupeids at $200 \mathrm{kHz}$}

For the $200 \mathrm{kHz}$, an inference can be made from the ratio of volume backscatter measurements of 38 $\mathrm{kHz}$ to different frequencies (i.e. $\mathrm{TS}_{200} / \mathrm{TS}_{38}=\mathrm{SV}_{200} / \mathrm{SV}_{38}$.) (Saunders et al 2012). The b20 parameter (the intercept $=-71.2$ ) established for the clupeid fish at $38 \mathrm{kHz}$ can be adjusted based on such multifrequency data. In order make such inference, a section of the data collected during the North Sea Herring acoustic survey in 2018 was used where species/size composition were identified as small sized clupeids by trawl catch. The analysis was performed with Echoview (version 9) as follows:

- The approximate area of occurrence of the targeted species in the water column was constrained by a polygon region on the $38 \mathrm{kHz}$ echogram (upper 20-30 m) with a $7 \mathrm{~m}$ upper boundary.

- Volume backscattering data (Sv) of all frequencies were smoothed by $5 \times 5$ median filter and filtered with $-65 \mathrm{~dB}$ re $1 \mathrm{~m}^{-1}$ lower threshold.

- A Boolean mask was created based on values at $38 \mathrm{kHz}$ where values excluded with threshold set to 0 and retained values set to 1 . Then the mask was applied to all smoothed echograms.

- Masked $38 \mathrm{kHz}$ echogram was subtracted from all other masked frequencies to calculate the relative frequency response. The values remained within the constrained region was exported as CSV file.

- The median of the distributions and their first and third quantiles are plotted in Figure 1

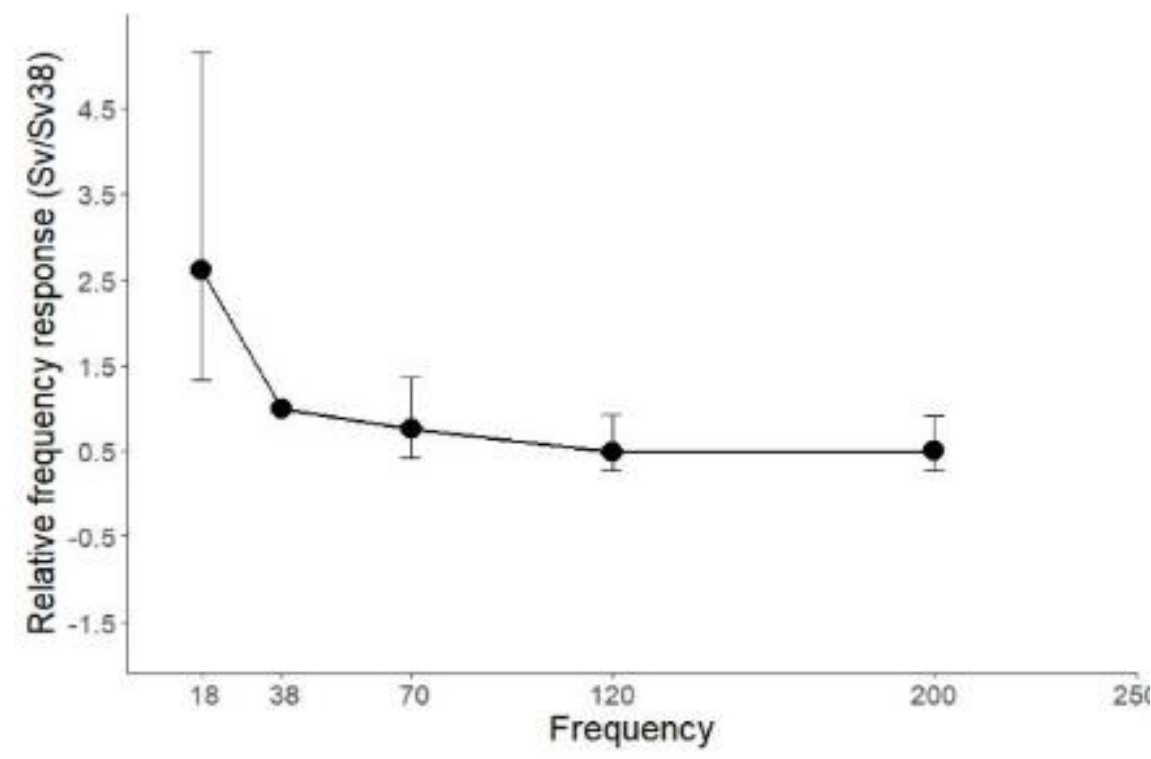

Figure 1 Measurements from the small size clupeids during 2018 North Sea Herring Survey (HERAS) 


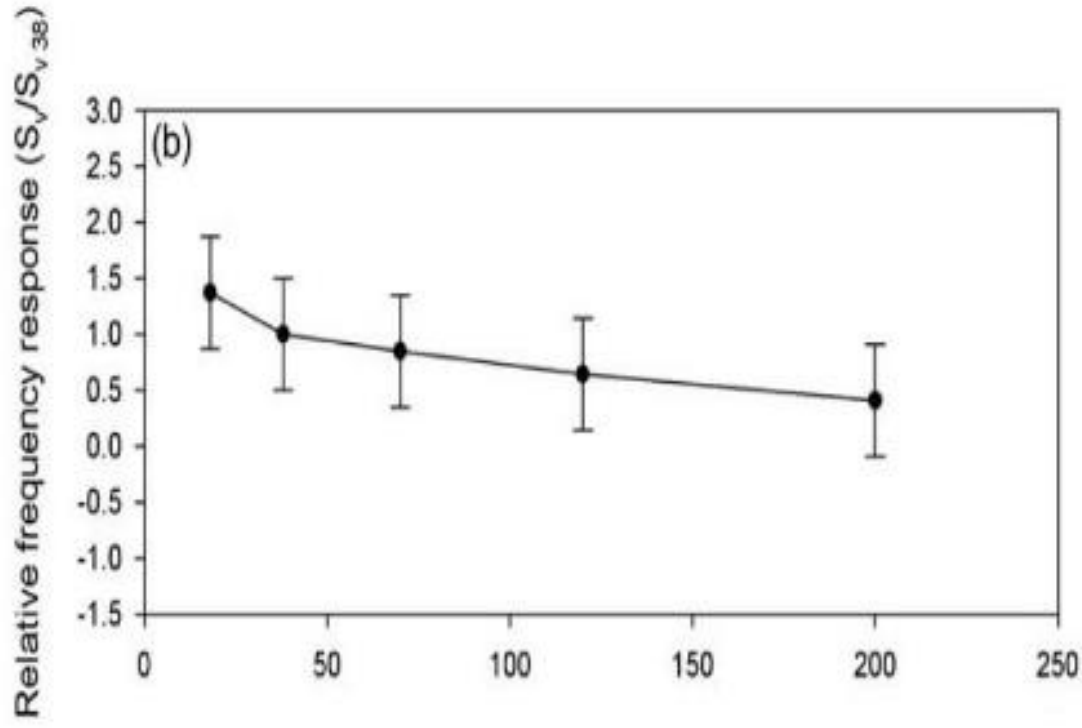

Figure 2 Saunders et al 2012 Figure 3 (b) measurements on herring in Norwegian Sea (1996-2010)

The Figure 2 is taken from Saunders et al (2012) for comparison with our results. Their data is from the ground-truthed adult herring recordings during herring surveys in the Norwegian Sea collected by the Institute of Marine Research (IMR). Despite the slight difference the shapes of the curves are similar with comparable average values and similar magnitudes in the differences between the frequencies. The observed median relative frequency responses in Figure 1 are:

Relative frequency response (Sv/Sv38) calculations as shown on Figure 1

\begin{tabular}{|r|r|r|r|}
\hline Frequency & Median & First quantile & Third quantile \\
\hline $\mathbf{1 8}$ & 2.603 & 1.32 & 5.15 \\
\hline $\mathbf{3 8}$ & 1 & 1 & 1 \\
\hline $\mathbf{7 0}$ & 0.755 & 0.42 & 1.37 \\
\hline $\mathbf{1 2 0}$ & 0.49 & 0.26 & 0.93 \\
\hline $\mathbf{2 0 0}$ & 0.496 & 0.27 & 0.91 \\
\hline
\end{tabular}

From the Table the adjustment to the b20 parameter (the intercept) of the target strength equation for $200 \mathrm{kHz}$ is $-3.045 \mathrm{~dB}$. As a result, the new TS /length equation is as follows:

TS $=20 \log _{10}[$ mean fish length $]-74.25$ 


\section{Annex 3 - Beam trawl catches}

Number of schools swimming fish species in the $3 \mathrm{~m}$ beam trawl hauls (Van Hal et al, 2017). Sandeel species (Ammodytes marinus, $A$. tobianus and Hyperoplus lanceolatus) have been grouped. Station 114-155 Zuid-Holland; 214-257 Noord-Holland; 314-357 Texel. D50 is the average sediment particle size and Secchi is the water visibility in meter as measured with a Secchi-disc.

\begin{tabular}{|c|c|c|c|c|c|c|}
\hline location & NASC & sandeel & herring & sprat & D50 & Secchi (m) \\
\hline 114 & 873 & 1 & 960 & 4 & 236.99 & 1.8 \\
\hline 115 & 475 & 0 & 1568 & 2 & 185.41 & 1.5 \\
\hline 116 & 3035 & 0 & 1824 & 2 & 133.41 & 1.5 \\
\hline 117 & 470 & 0 & 1248 & 0 & 147.78 & 1.8 \\
\hline 125 & 124 & 1 & 344 & 1 & 235.11 & 2 \\
\hline 126 & 103 & 1 & 56 & 5 & 250.68 & 2.2 \\
\hline 127 & 52 & 0 & 352 & 0 & 163.23 & 2.2 \\
\hline 154 & 853 & 1 & 18 & 0 & 204.00 & 2 \\
\hline 155 & 406 & 6 & 3045 & 8 & 620.82 & 2.2 \\
\hline 214 & 1913 & 2 & 180 & 0 & 240.23 & 1.6 \\
\hline 215 & 5383 & 1 & 280 & 3 & 210.61 & 1.8 \\
\hline 216 & 5544 & 0 & 32 & 0 & 174.31 & 1.8 \\
\hline 217 & 2440 & 0 & 11 & 0 & 167.62 & 2.3 \\
\hline 227 & 64 & 0 & 0 & 0 & 174.55 & 2.8 \\
\hline 235 & 55 & 0 & 0 & 0 & 276.82 & 2.7 \\
\hline 236 & 14 & 0 & 0 & 0 & 195.74 & 2.6 \\
\hline 244 & 16168 & 0 & 0 & 66 & 247.67 & 1.2 \\
\hline 245 & 904 & 0 & 6 & 0 & 269.10 & 1.5 \\
\hline 247 & 1277 & 0 & 0 & 0 & 203.68 & 2.1 \\
\hline 254 & 1117 & 1 & 43 & 1 & 250.45 & 2.5 \\
\hline 257 & 1891 & 0 & 1 & 1 & 161.26 & 2.6 \\
\hline 314 & 929 & 1 & 19 & 2 & 307.85 & 3.2 \\
\hline 315 & 4871 & 0 & 17 & 1 & 210.11 & 3.5 \\
\hline 316 & 191 & 4 & 16 & 0 & 210.43 & 2.4 \\
\hline 317 & 3455 & 10 & 44 & 0 & 519.96 & 2.8 \\
\hline 324 & 43 & 2 & 6 & 2 & & 1.3 \\
\hline 325 & 930 & 3 & 1 & 1 & & 1.2 \\
\hline 326 & 135 & 5 & 0 & 1 & & 1.3 \\
\hline 327 & 1200 & 20 & 0 & 0 & & 1.8 \\
\hline 334 & 21 & 1 & 1 & 1 & & 1.5 \\
\hline 335 & 488 & 0 & 0 & 0 & & 1.8 \\
\hline 336 & 15 & 5 & 0 & 0 & 632.66 & 2 \\
\hline 337 & 70 & 10 & 0 & 0 & 292.16 & 2 \\
\hline 344 & 632 & 0 & 6 & 0 & & 1.8 \\
\hline 345 & 7976 & 0 & 0 & 0 & 242.45 & 2 \\
\hline 346 & 375 & 0 & 5 & 0 & & 2.5 \\
\hline 347 & 776 & 14 & 0 & 0 & 232.25 & 2.8 \\
\hline 354 & 800 & 0 & 3 & 0 & & 1.5 \\
\hline 355 & 740 & 0 & 6 & 1 & & 2 \\
\hline 356 & 1298 & 0 & 0 & 0 & 253.88 & 2.5 \\
\hline 357 & 2521 & 17 & 11 & 0 & 219.80 & 2.8 \\
\hline
\end{tabular}




\section{Annex 4 - NASC distribution maps}

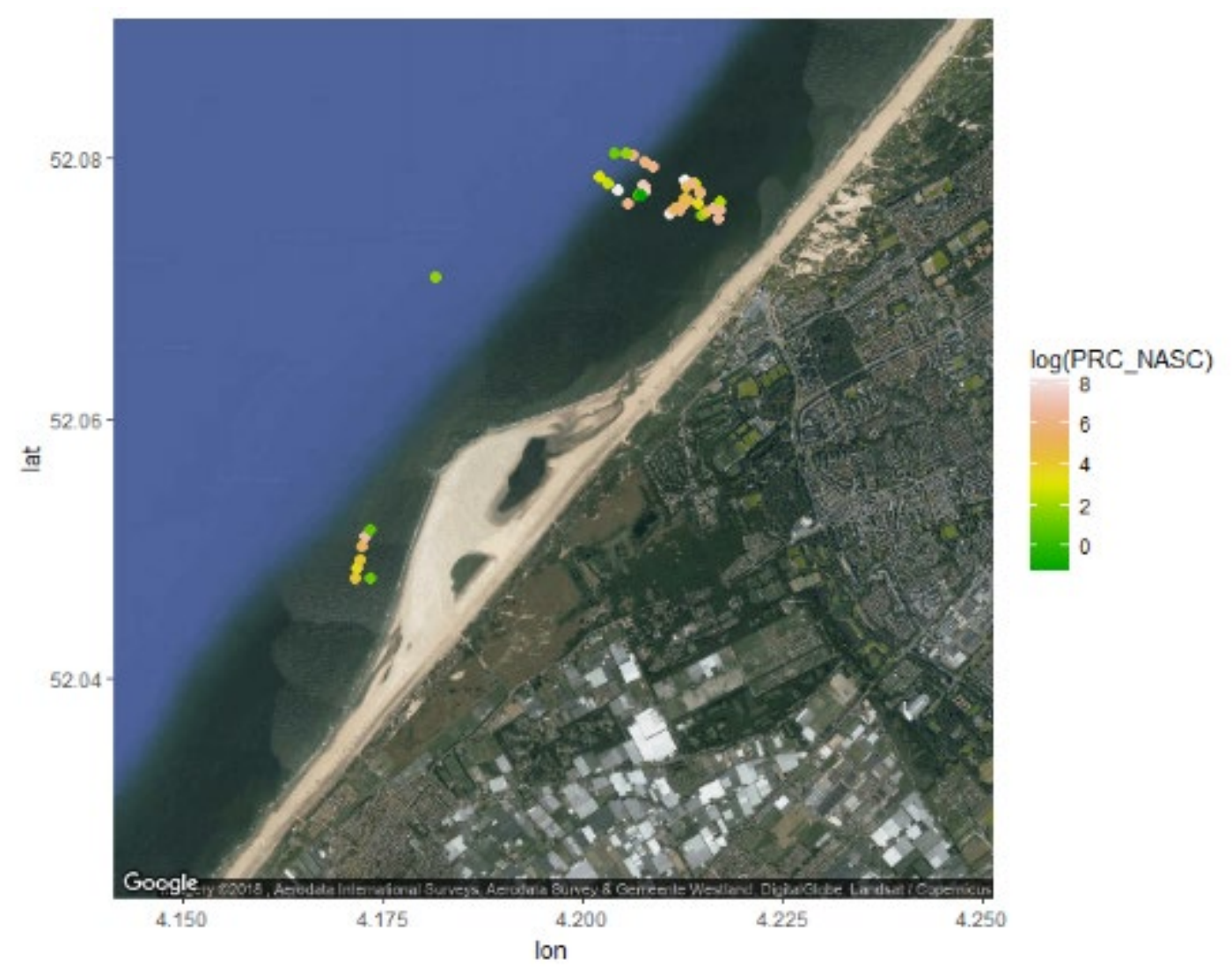

Figure 1. NASC Distribution map for 13-7-2017, Zuid-Holland. Logarithmic colour scale. Black dots are zeroes.

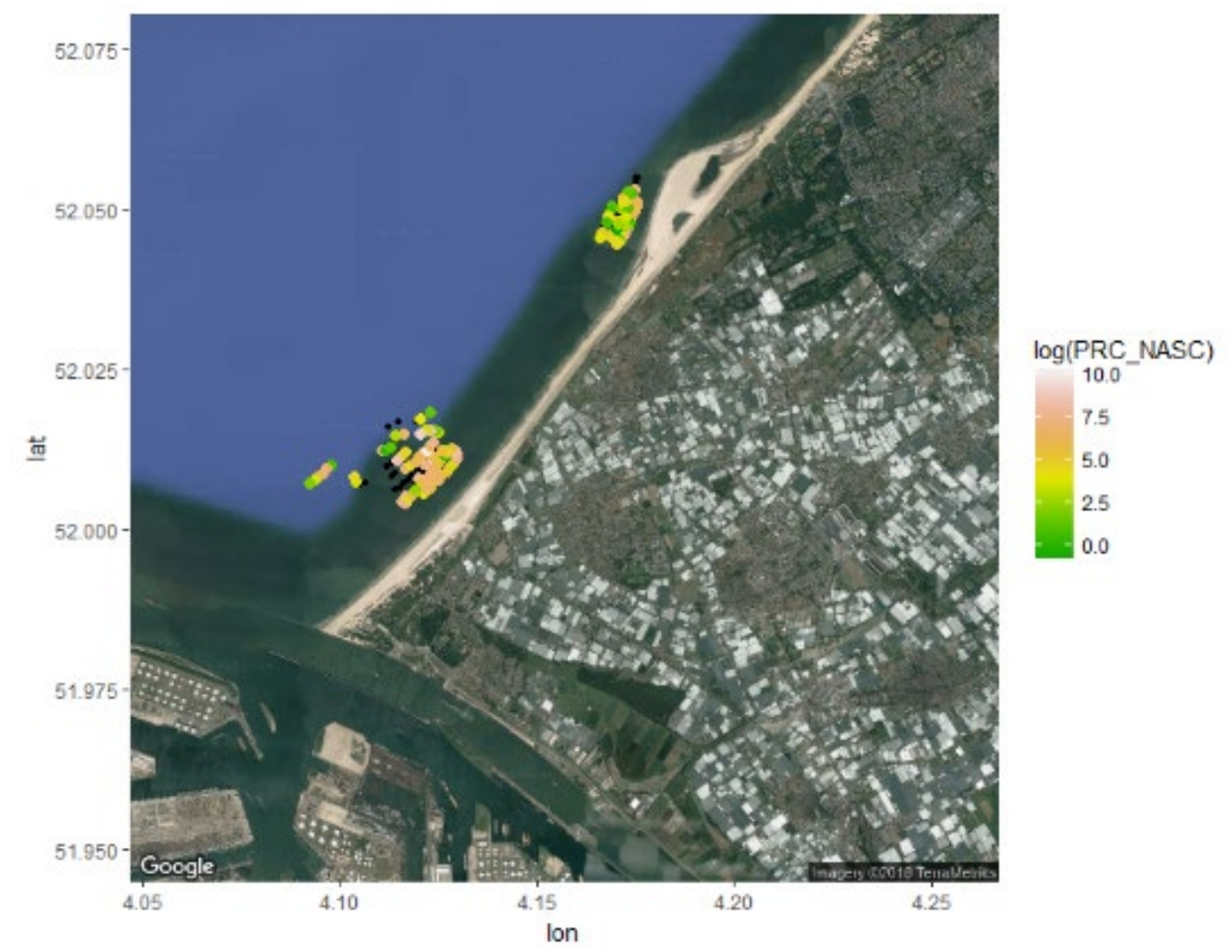

Figure 2. NASC Distribution map for 14-6-2017, Zuid-Holland. Logarithmic colour scale. Black dots are zeroes. 


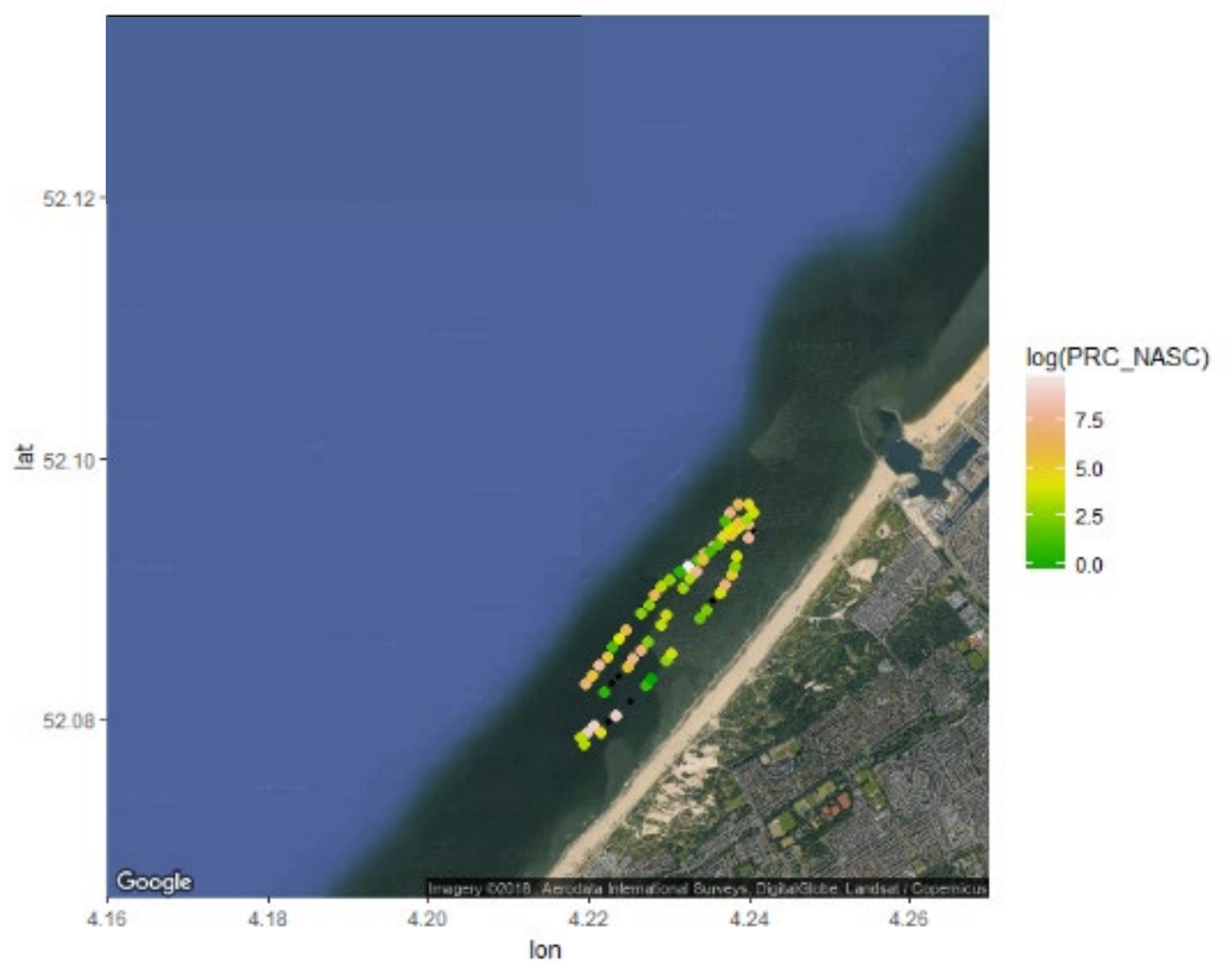

Figure 3. NASC distribution map for 15-6-2017, Zuid-Holland. Logarithmic colour scale. Black dots are zeroes.

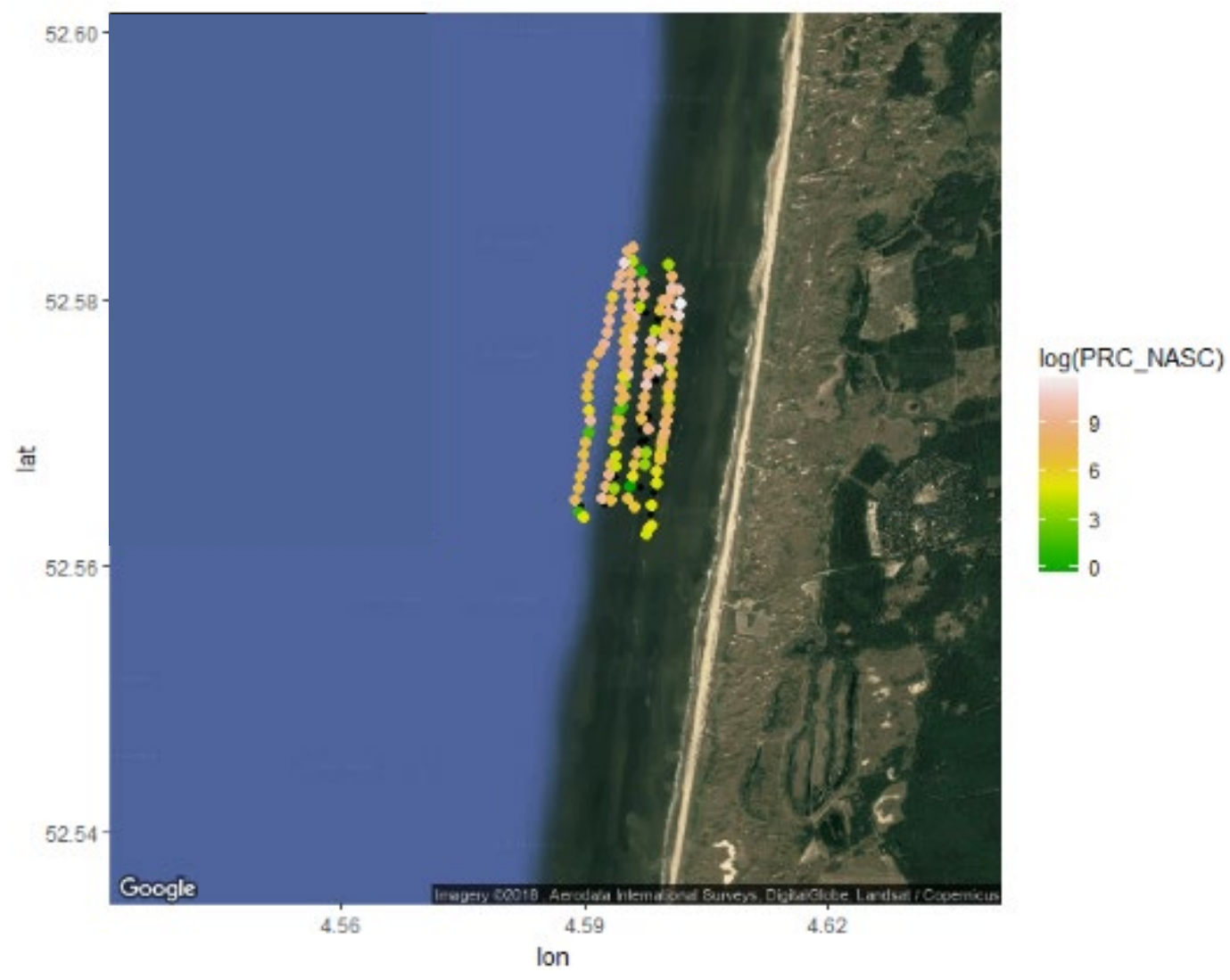

Figure 4. Distribution map for 19-6-2017, Noord-Holland. Logarithmic colour scale. Black dots are zeroes. 


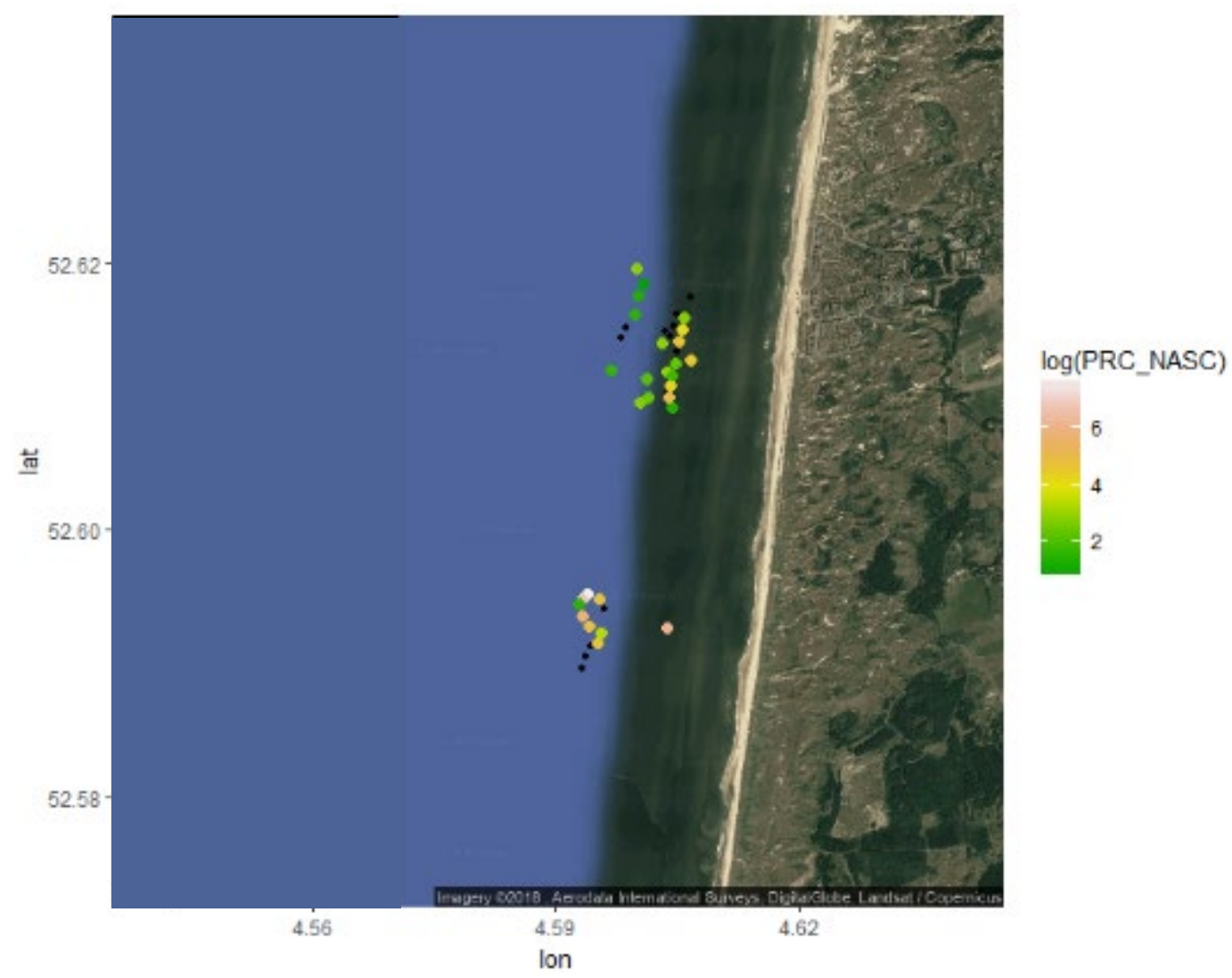

Figure 5. Distribution map for 20-6-2017, Noord-Holland. Logarithmic colour scale. Black dots are zeroes.

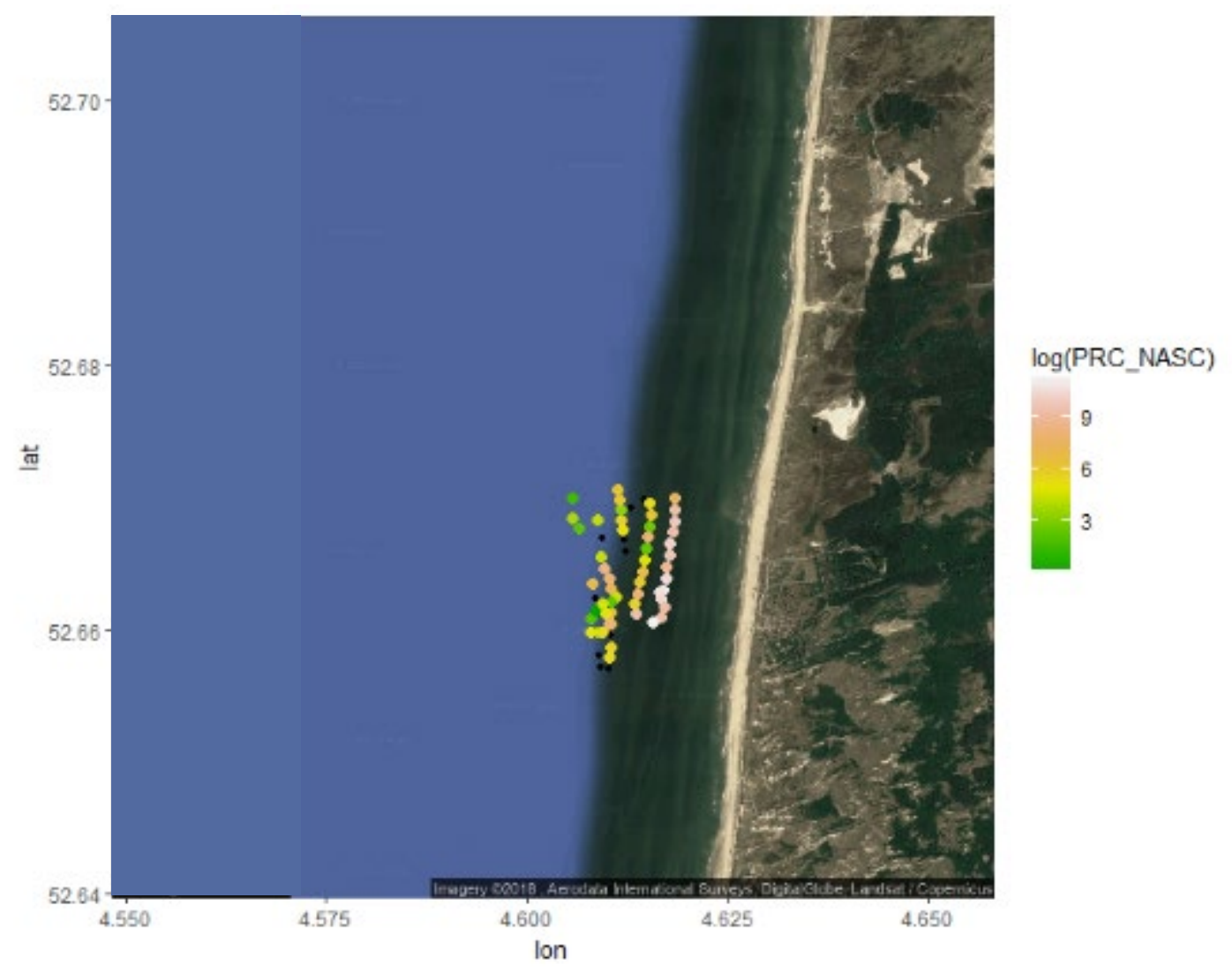

Figure 6. NASC Distribution map for 21-6-2017, Noord-Holland. Logarithmic colour scale. Black dots are zeroes. 


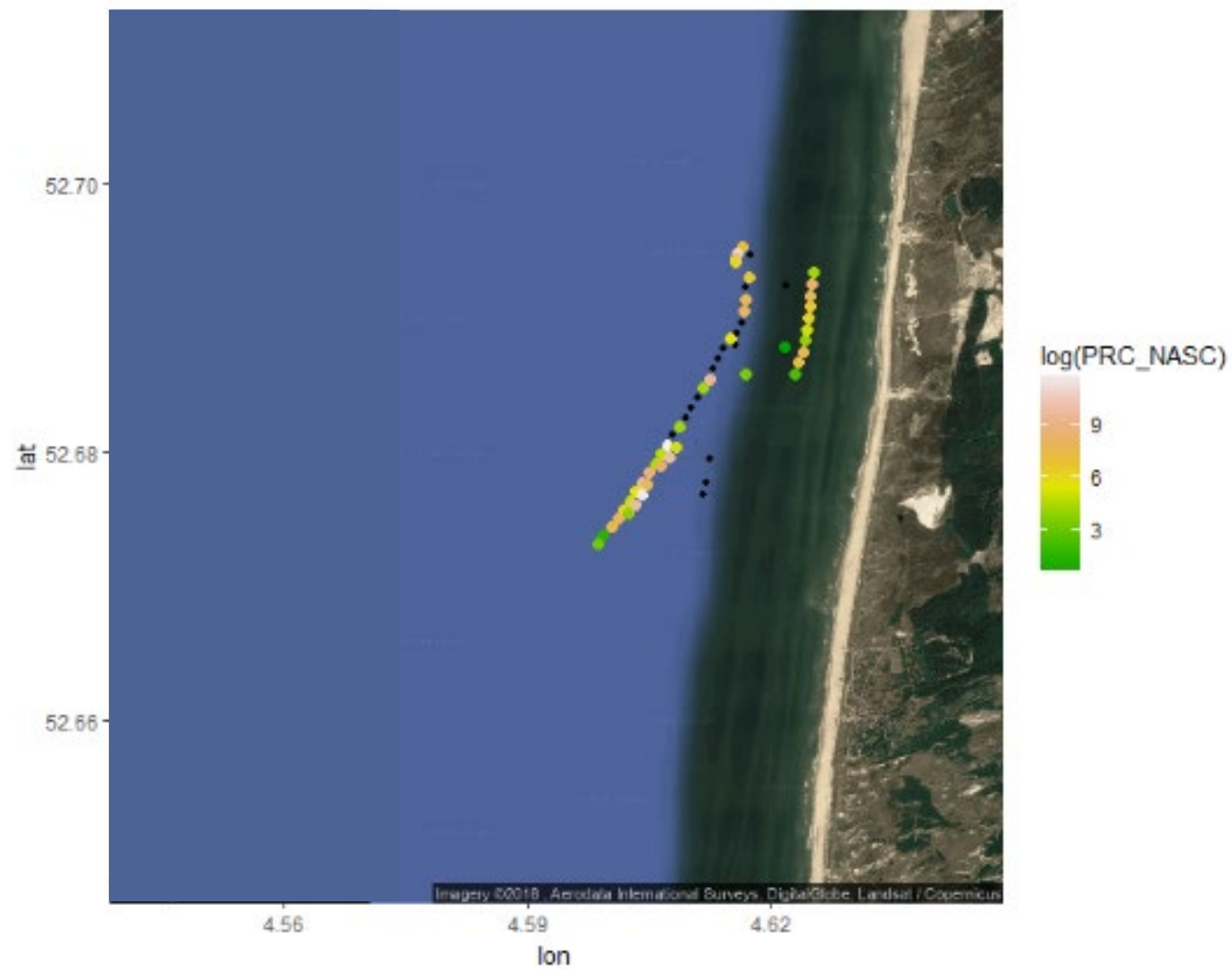

Figure 7. NASC Distribution map for 22-6-2017, Noord-Holland. Logarithmic colour scale. Black dots are zeroes.

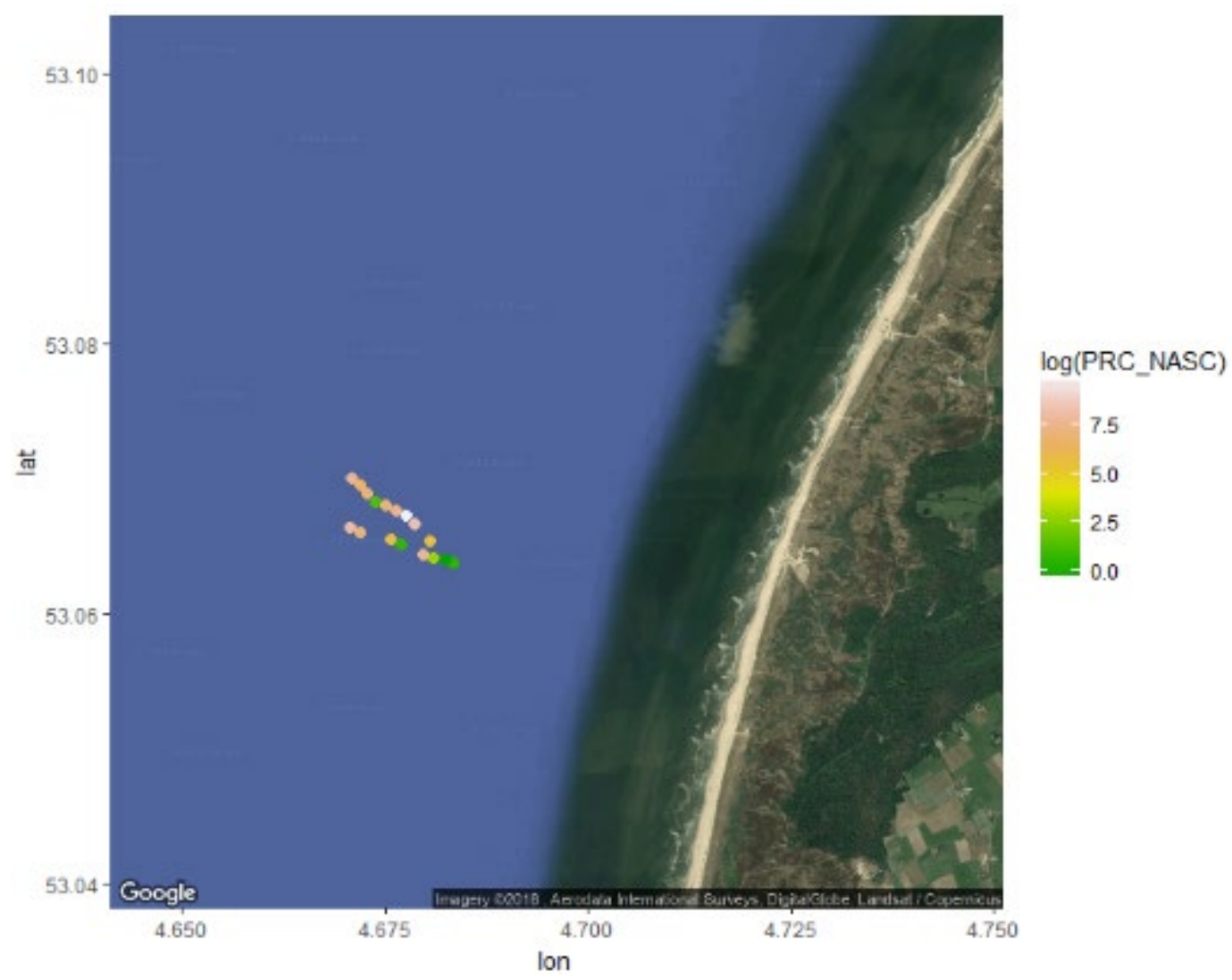

Figure 8. NASC Distribution map for 26-6-2017, Texel. Logarithmic colour scale. Black dots are zeroes. 


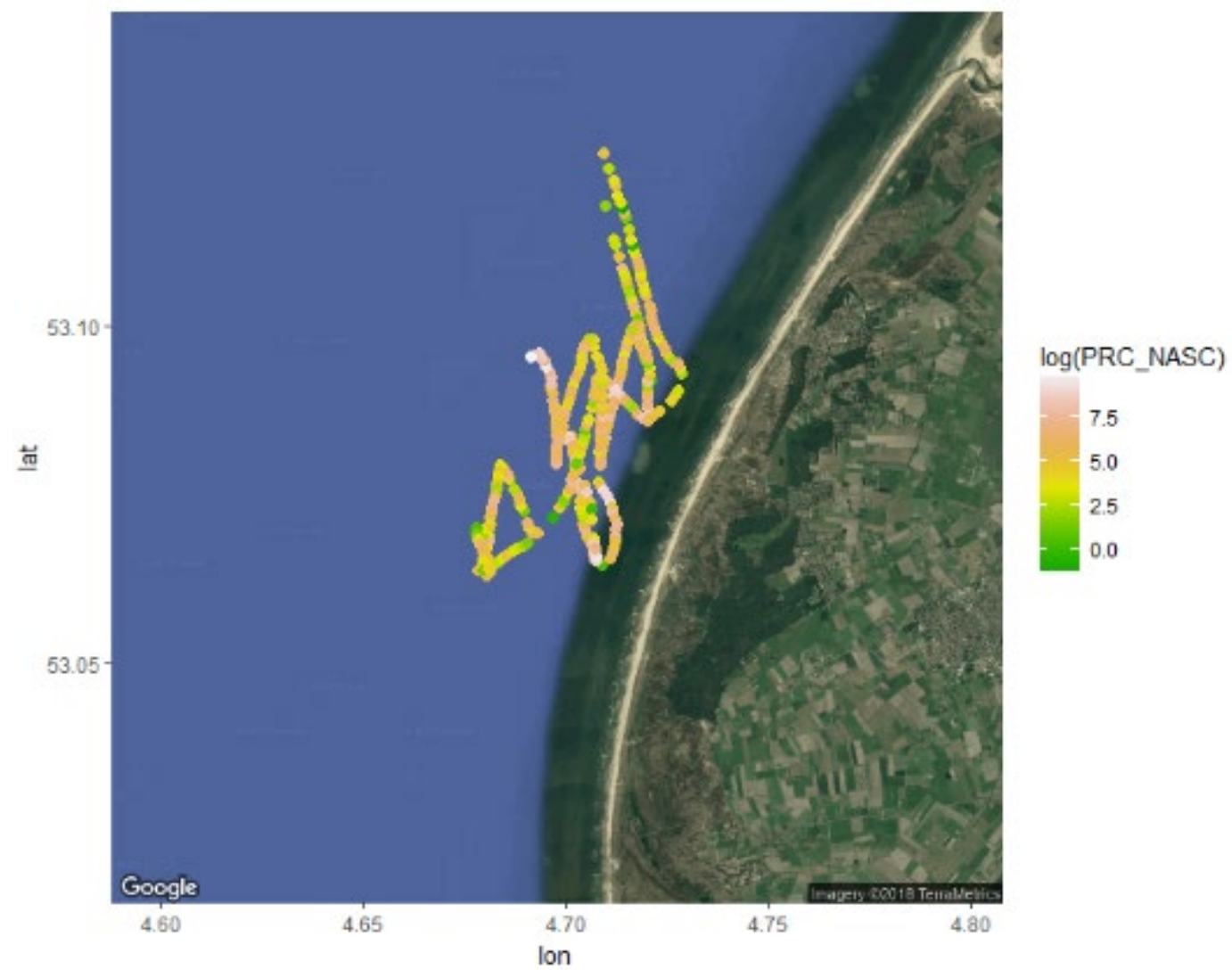

Figure 9. NASC Distribution map for 27-6-2017, Texel. Logarithmic colour scale. Black dots are zeroes.

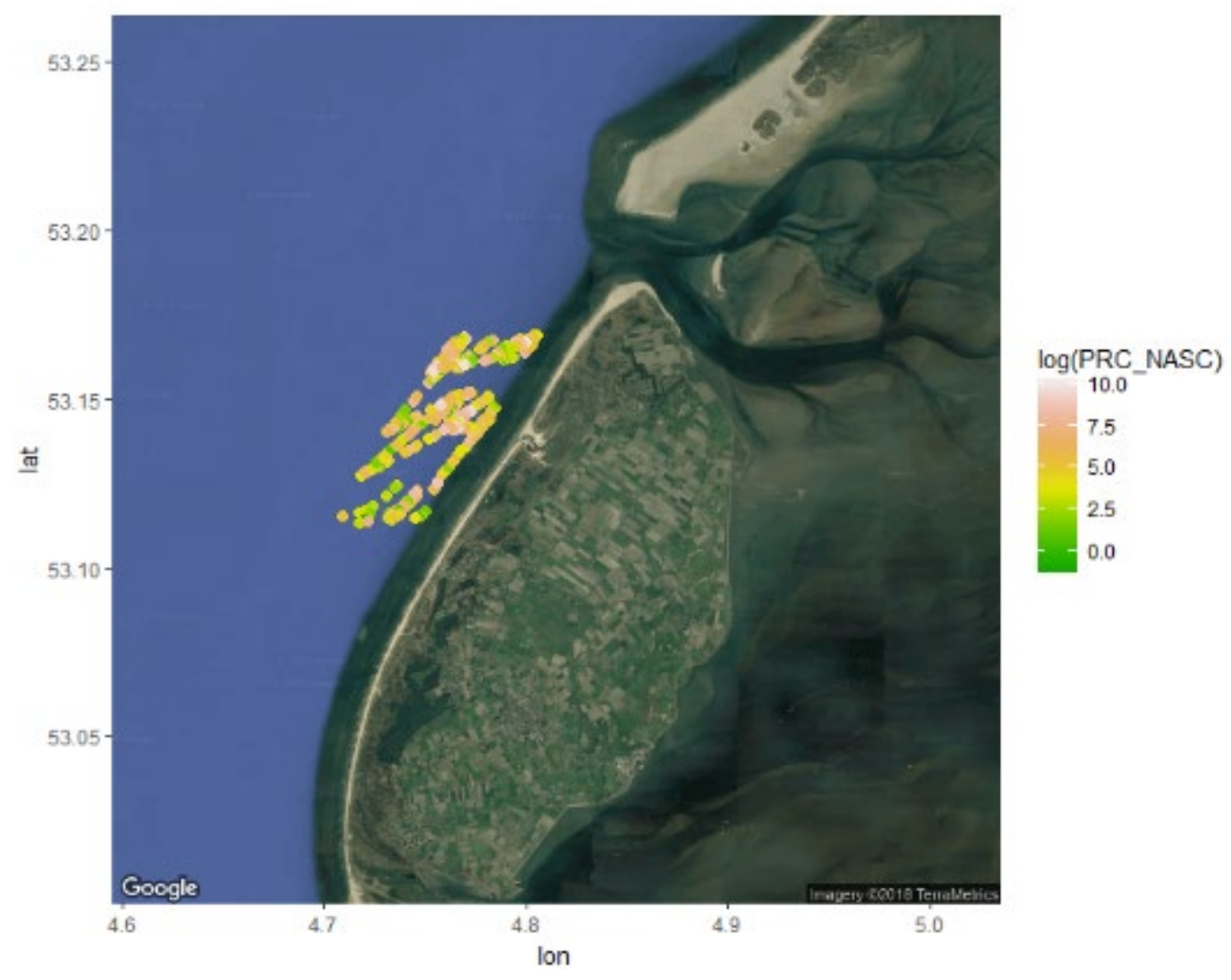

Figure 10. NASC Distribution map for 29-6-2017, Texel. Logarithmic colour scale. Black dots are zeroes. 


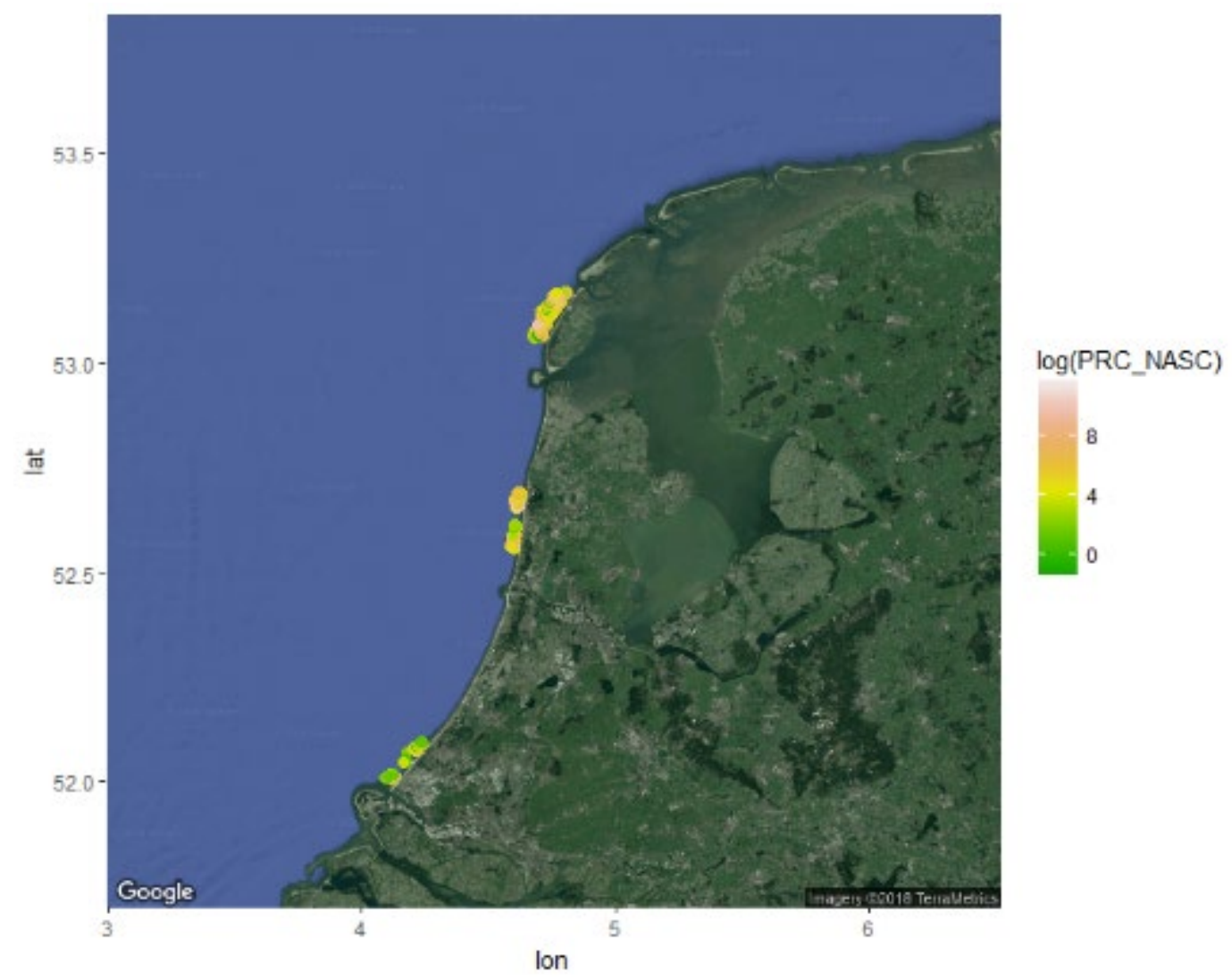

Figure 11. Overview NASC Distribution map for 13-29 June 2017. Logarithmic colour scale. Black dots are zeroes.

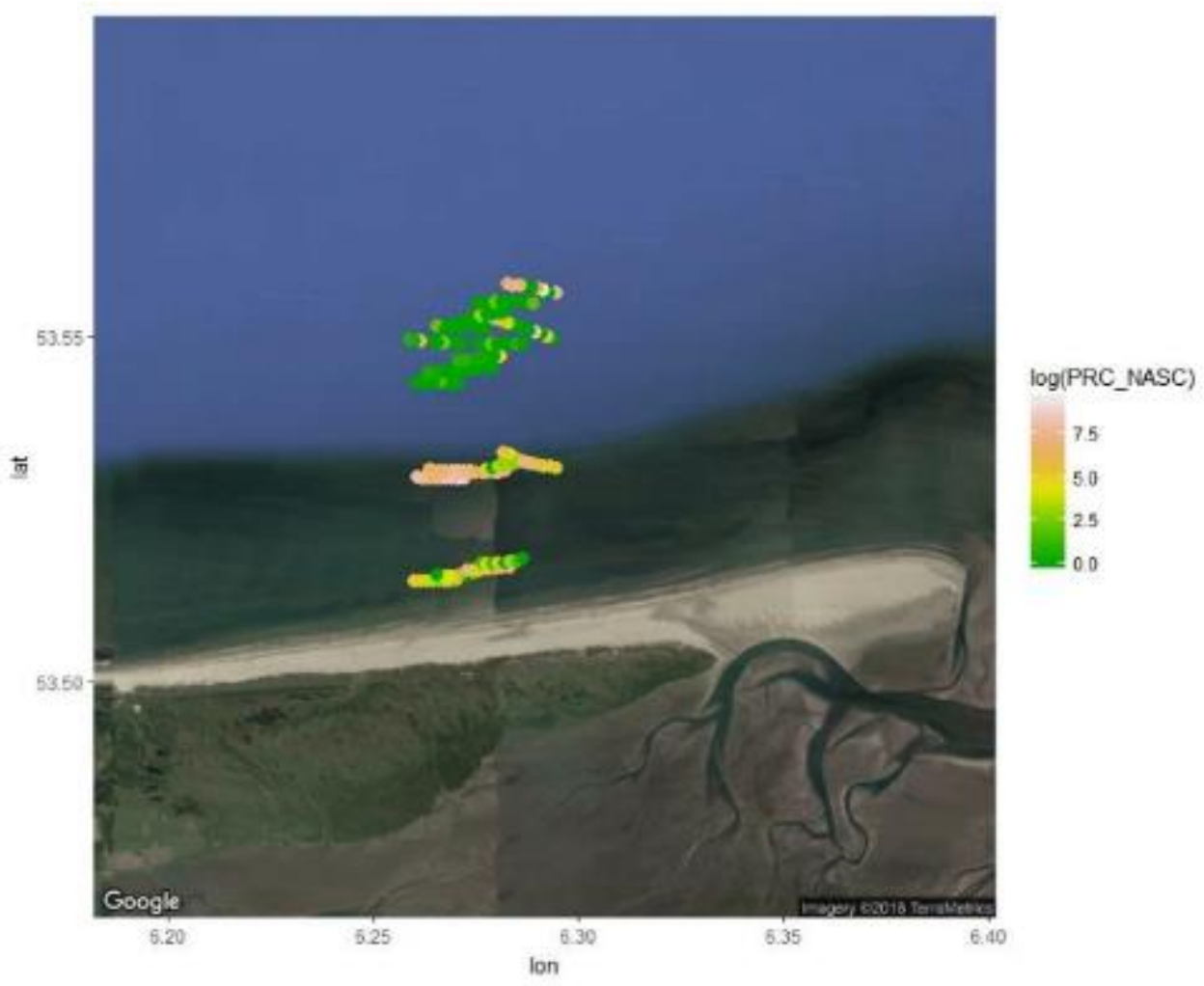

Figure 12. Overview NASC Distribution map for 13-29 June 2018 at Schiermonnikoog. Logarithmic colour scale. Black dots are zeroes. 


\section{Annex 5 - Example of large concentrations of pelagic fish schools at Noord-Holland}

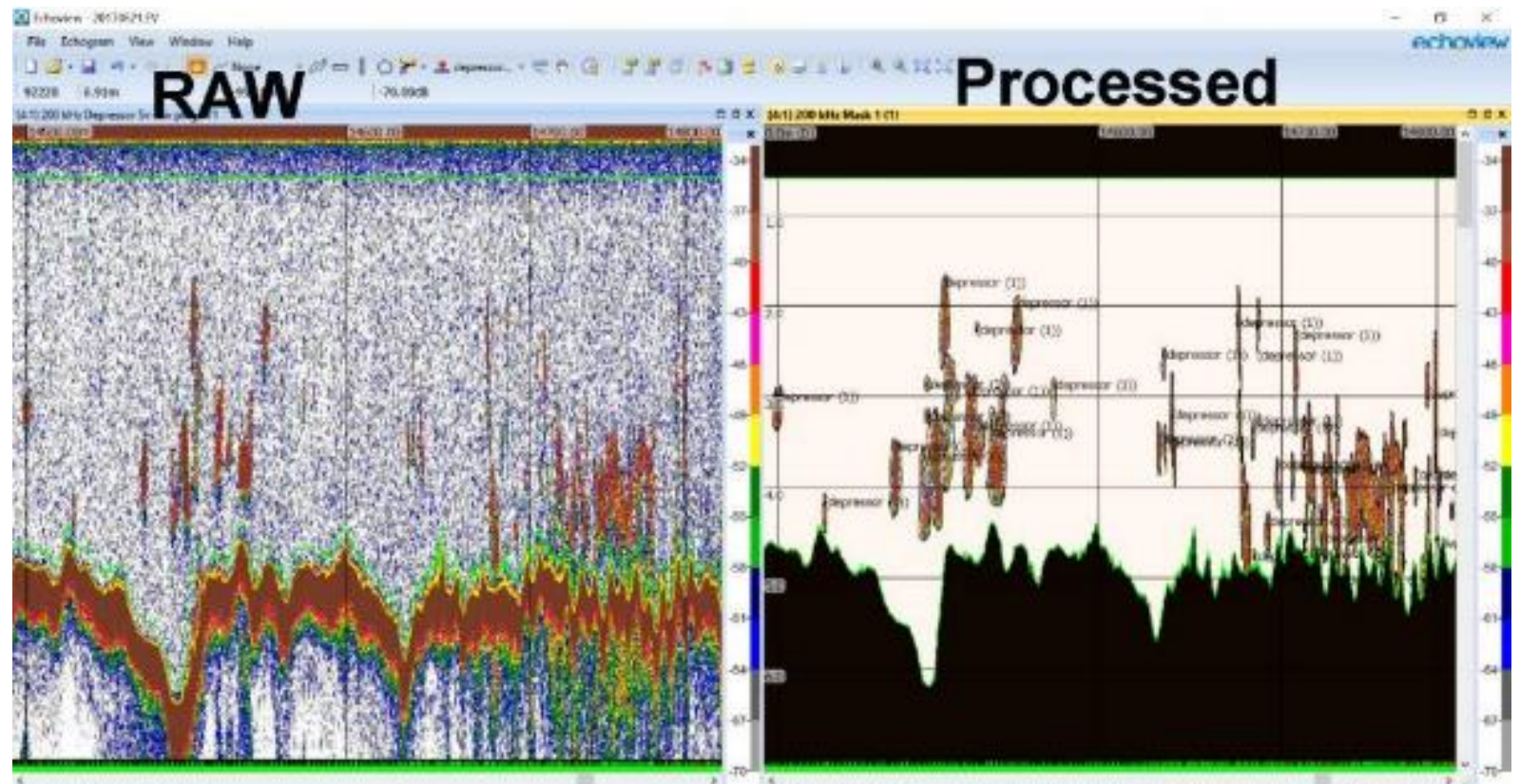

Example of an echogram on 21 June 2017 at the location of Noord-Holland during the haul. These concentrations of schools add to the high NASC values found at this location. In 2018 at Schiermonnikoog this kind of extended concentrations were not found. 


\title{
Annex 6 - GAM results depth, time of the day and tidal phase
}

\author{
Family: gaussian \\ Link function: identity \\ Formula: \\ 1ogNASC $\sim 10 \mathrm{ca} 1+\mathrm{s}($ depth $)+\mathrm{s}($ time_of_day $)+\mathrm{s}($ tide $)$ \\ Parametric coefficients:

$\begin{array}{lrrrr} & \text { Estimate } & \text { std. Error } t \text { value } & \operatorname{Pr}(>|t|) \\ \text { (Intercept) } & 1.9570 & 0.3614 & 5.416 & 7.84 \mathrm{e}-06 \\ \text { localscheveningen } & -0.6146 & 0.4687 & -1.311 & 0.20 \\ \text { 1ocalTexe1 } & -0.6038 & 0.5368 & -1.125 & 0.27\end{array}$

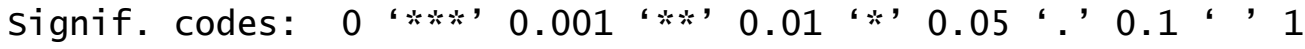 \\ Approximate significance of smooth terms:

$\begin{array}{lrrrr} & \text { edf } & \text { Ref.df } & \text { F } & \text { p-value } \\ \text { s(depth) } & 1.000 & 1.000 & 0.371 & 0.547 \\ \text { s(time_of_day) } & 1.813 & 2.278 & 0.737 & 0.442 \\ \text { s(tide) } & 1.000 & 1.000 & 1.452 & 0.238 \\ \text { R-sq.(adj) }= & 0.00293 & \text { Deviance explained }=16.9 \%\end{array}$ \\ $\mathrm{GCV}=1.1609$ Scale est. $=0.94122 \quad \mathrm{n}=36$
}

$\operatorname{logNASC}$ vs. $s \quad \operatorname{logNASC}$ vs. $s \quad \operatorname{logNASC}$ vs. $s$ (depth)
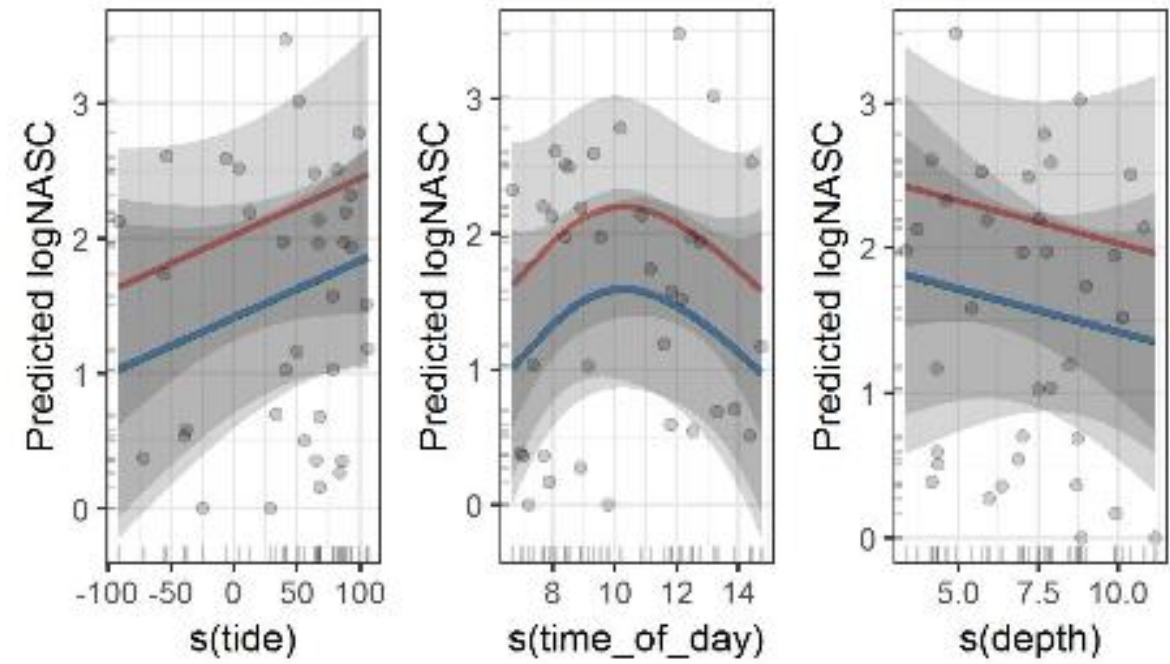

local

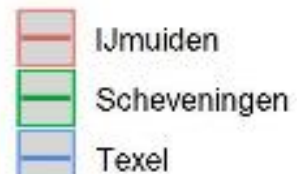

Results of the GAM analysis. The acoustic fish density represented as a function of tide (sea surface height), time of the day and depth. Different coloured curves represent the effect of different locations (the green line of Scheveningen is covered entirely by the blue line of Texel). IJmuiden was significantly different from Texel and Scheveningen. The shaded regions on the plot shows the range of the standard error of the model fit. 
Wageningen Marine Research

$\mathrm{T}+31(0) 317480900$

E: marine-research@wur.nl

www.wur.eu/marine-research

Visitors' address

- Ankerpark 271781 AG Den Helder

- Korringaweg 7, 4401 NT Yerseke

- Haringkade 1, 1976 CP IJmuiden
With knowledge, independent scientific research and advice, Wageningen Marine Research substantially contributes to more sustainable and more careful management, use and protection of natural riches in marine, coastal and freshwater areas.

Wageningen Marine Research is part of Wageningen University \& Research. Wageningen University \& Research is the collaboration between Wageningen University and the Wageningen Research Foundation and its mission is: 'To explore the potential for improving the quality of life' 